INSTITUTO DE PESQUISAS ENERGÉTICAS E NUCLEARES

Autarquia associada à Universidade de São Paulo

DESENVOLVIMENTO DE BIOMARCADOR ESPECÍFICO DE CÉLULAS BETA PANCREÁTICAS (INCRETINA RADIOMARCADA) PARA IMAGEM DA MASSA BETA FUNCIONAL EM DIABÉTICOS E OBESOS: ESTUDO EM MODELO ANIMAL

DANIELE SEO

Tese apresentada como parte dos requisitos para obtenção do Grau de Doutor em Ciências na Área de Tecnologia Nuclear - Aplicações

Orientadora:

Dra. Bluma Linkowski Faintuch 
Dedico a Deus, meus pais

Emília e Bernardo e ao meu esposo Anderson. 
“O aprendizado é um tesouro que acompanha seu dono em todos os lugares".

Luigi Pirandello

"O limite do homem é o limite de seus sonhos"

John Fitzgerald Kennedy 


\section{AGRADECIMENTOS}

À Deus, pelo dom da vida e por tornar possível mais uma etapa em minha vida.

À minha orientadora, Dra. Bluma Linkowski Faintuch, pela dedicação e por acreditar na importância técnica e científica deste trabalho, e principalmente por acreditar no meu potencial como aluna e profissional.

Um educador é aquele que busca ensinar, orientar e ser amigo.

Durante o Doutorado você soube ensinar e incentivar, exigir e respeitar, persistir e acreditar. Obrigada pela confiança $e$ amizade que recebi durante todo este tempo.

Ao meu pai, Bernardo Makoto Seo, cujo exemplo de trabalhador sempre me guiou em minha vida e por todos os momentos felizes que desfrutamos juntos.

Você, em todos os momentos que tive dúvida, em poucas palavras, me guiou e incentivou, numa constante doação de amor.

À minha mãe, Emília Satoshi Miyamaru Seo, que me apoia e orienta de forma incondicional, levando-me à realização de meus sonhos.

$\mathrm{Na}$ vida escolhemos os espelhos onde queremos ver nossas imagens refletidas. Você é meu espelho espiritual, meu exemplo moral e de força para viver cada dia como uma lição de aprendizado.

Ao meu esposo, Anderson Massaiti Hieda, pela pessoa única, compreensiva, amiga, engraçada, por estar sempre presente, torcer por um fim comum e por dividir todos os nossos sonhos e momentos que fazem de mim o que sou. 
Sozinho vamos mais rápido, juntos vamos mais longe.

À minha irmã Juliana Seo e meu cunhado Élio Hitoshi Shinohara, por todos os momentos felizes que passamos juntos.

À Universidade de São Paulo (USP) e ao Instituto de Pesquisas Energéticas e Nucleares (IPEN-CNEN/SP), na pessoa do Sr. Superintendente Dr. Jose Carlos Bressiani, pela oportunidade concedida para executar esse trabalho.

Ao Conselho Nacional de Pesquisa e Desenvolvimento (CNPq) pela concessão da bolsa de Doutorado e oportunidade concedida para execução do presente trabalho.

Aos profissionais do Biotério do IPEN-CNEN/SP, especialmente a Prof. Dra. Nanci do Nascimento e Sra. Maria Neide Ferreira Mascarenhas, por permitir o uso do Biotério e pelos animais concedidos para execução deste trabalho.

Ao Natanael Gomes da Silva, pelo auxílio na aquisição das imagens cintilográficas.

Ao Departamento de Estomatologia da Faculdade de Odontologia da Universidade de São Paulo (FOUSP) e ao Centro Veterinário de Anatomia Patológica (CVAP) pelo auxílio e colaboração nos ensaios experimentais histológicos e liberação de laudos anatomopatológicos.

Aos colegas do Centro de Radiofarmácia do IPEN-CNEN/SP, Érica Aparecida de Oliveira, Ana Funari, Angélica Berbezan e Aryel Heitor Ferreira pela ajuda nos 
experimentos, convivência, apoio sempre que preciso e por todos os bons momentos que passamos juntos.

E, finalmente, a todos aqueles que direta ou indiretamente contribuíram para concretização deste trabalho.

Muito obrigada! 


\title{
DESENVOLVIMENTO DE BIOMARCADOR ESPECÍFICO DE CÉLULAS BETA PANCREÁTICAS (INCRETINA RADIOMARCADA) PARA IMAGEM DA MASSA BETA FUNCIONAL EM DIABÉTICOS E OBESOS: ESTUDO EM MODELO ANIMAL
}

\author{
Daniele Seo
}

\begin{abstract}
RESUMO
O aumento nos casos de obesidade em todo o mundo tem gerado grande preocupação e estimulado pesquisas na prevenção e tratamento dessa condição patológica. A combinação de diabetes tipo 2 ou resistência insulínica com obesidade agrava o potencial evolutivo da enfermidade. Mesmo pacientes submetidos com sucesso à cirurgia bariátrica ou metabólica, podem não se curar do diabetes, pois a melhora das taxas circulantes de glicose e insulina nem sempre corresponde à recuperação da massa beta pancreática. Até o momento, não há consenso sobre como medir a massa de células beta in vivo. As ferramentas disponíveis padecem de baixa sensibilidade e especificidade, muitas vezes revelando-se também complexas e dispendiosas. Incretinas radiomarcadas ,como os análogos do peptídeo "glucagon-like-peptide-1 / GLP-1", têm-se revelado promissoras para avaliação de células beta pancreáticas, em diabetes e insulinoma. $O$ objetivo do presente trabalho foi o desenvolvimento de dois conjugados de análogo de incretina GLP-1, marcados com tecnécio-99m, a fim de propor um método não invasivo de imagem, para monitoração da massa de células beta pancreáticas, em organismos afetados por obesidade. O estudo foi conduzido em diferentes modelos animais, incluindo obesidade induzida por dieta hiperlipídica, estado pós-obesidade em que o distúrbio inicialmente gerado foi parcialmente corrigido, e como controle, diabetes induzido com aloxana. Nos resultados, os radiotraçadores alcançaram um rendimento radioquímico superior a $97 \%$. O melhor radiomarcador, dentre os dois análogos ensaiados, foi o ${ }^{99 \mathrm{~m}} \mathrm{TC}$-HYNIC-BAla-Exendin-4. Animais com obesidade induzida por dieta revelaram captação reduzida nas células beta pancreáticas. A restrição dietética (estado pós-obesidade) não se seguiu de recuperação completa, embora notável melhora de glicemia haja sido observada. Estudos futuros são indicados em modelos de obesidade, diabetes tipo 2 e tratamento dietético, incluindo cirurgia bariátrica e metabólica.
\end{abstract}

Palavras-chaves: incretinas, tecnécio-99m, obesidade, diabetes 


\title{
DEVELOPMENT OF BIOMARKER SPECIFIC OF PANCREATIC BETA CELLS (INCRETIN RADIOLABELLED) FOR IMAGE OF BETA FUNCTIONAL MASS IN DIABETIC AND OBESE: STUDY IN ANIMAL MODEL
}

\section{Daniele Seo}

\begin{abstract}
Increased prevalence of obesity worldwide, has become a vast concern, stimulating investigations focusing prevention and therapy of this condition. The association of type 2 diabetes or insulin resistance aggravates the prognosis of obesity. Even patients successfully submitted to bariatric or metabolic surgery, may not be cured of diabetes, as improvement of circulating values of glucose and insulin not necessarily reflects recovery of pancreatic beta cell mass. There is no consensus about how to estimate beta cell mass in vivo. Available tools suffer from low sensitivity and specificity, often being as well cumbersome and expensive. Radiolabeled incretins, such as glucagon-like-peptide 1 (GLP-1) analogs, seem to be promising options for the measurement of beta cell mass in diabetes and insulinoma. The objective of this study was the development of two conjugates of GLP-1 analog, radiolabeled with $99 \mathrm{~m}$ Technetium, as a noninvasive imaging method for the estimation of pancreatic beta cell mass, in the presence of obesity. Animal models were selected, including hyperlipidic diet-induced obesity, diet restricted obesity, and as controls, alloxan diabetes. Results indicated that both radiotracers achieved over $97 \%$ radiochemical yield. The most successful product was ${ }^{99 m}$ Tc-HYNIC-BAlaExendin-4. Low beta cell mass uptake occurred in diet-induced obesity. Dietrestricted obesity, with substantial shedding of excess body weight, was followed by remarkable decrease of fasting blood glucose, however beta cell mass uptake was only mildly improved. Future studies are recommended in obesity, type 2 diabetes, and dieting, including bariatric and metabolic operations.
\end{abstract}

Keywords: incretins, technetium-99m, obesity, diabetes 


\section{SUMÁRIO}

Página

1. INTRODUÇÃO

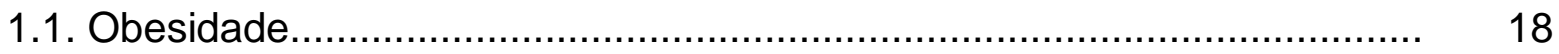

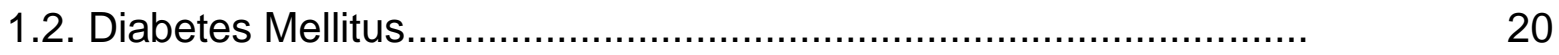

1.2.1. Diabetes Mellitus Tipo 1 (DM1) ..................................................... 21

1.2.2. Diabetes Mellitus Tipo 2 (DM2)..................................................... 22

1.2.3. Diabetes Mellitus Gestacional (DMG).............................................. 24

1.3. Hormônios secretados pelo pâncreas reguladores de glicose............. 24

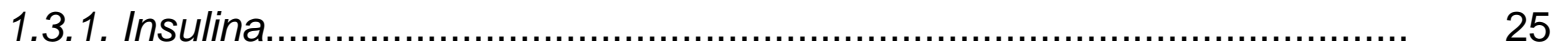

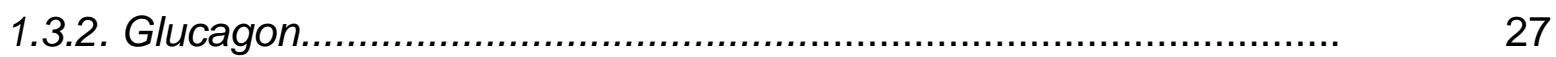

1.3.3. Somatostatina...................................................................... 28

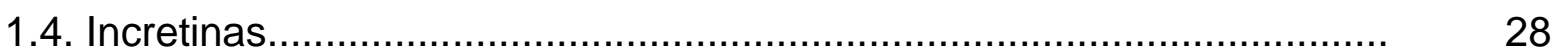

1.5. Radioisótopo tecnécio - 99m.............................................................. 33

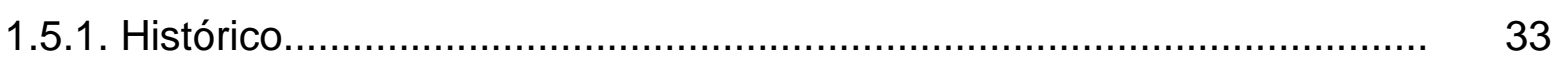

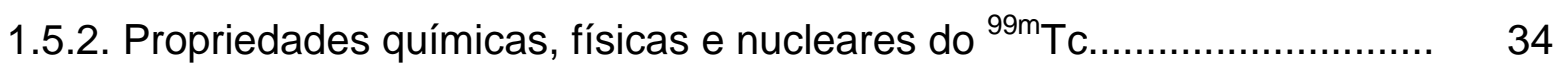

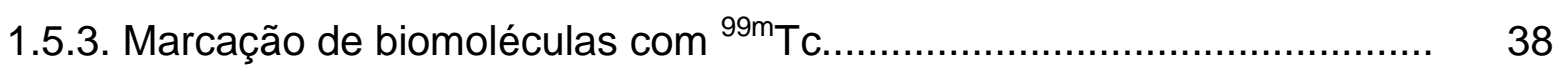

1.6. Agente quelante bifuncional.......................................................... 39

1.6.1. 6-hidrazinonicotinamida (HYNIC) como agente quelante

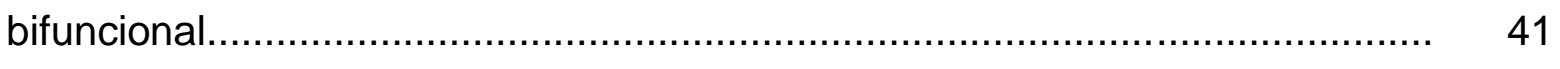

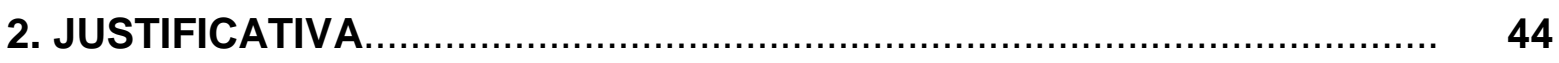

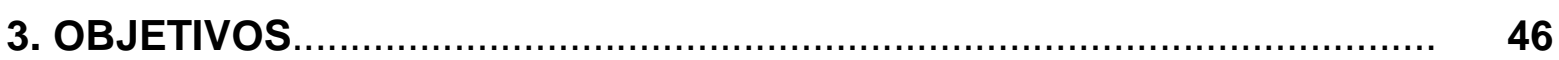

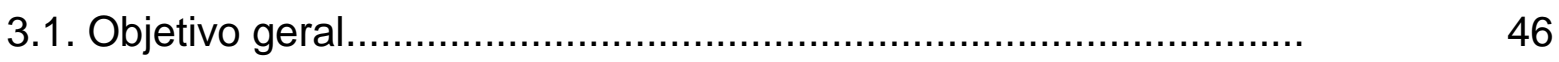

3.2. Objetivos específicos...............................................................

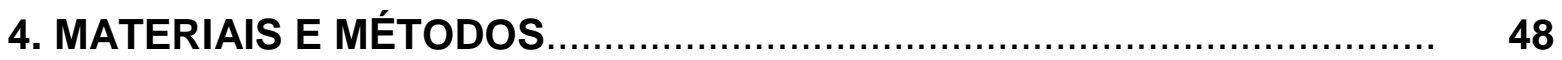

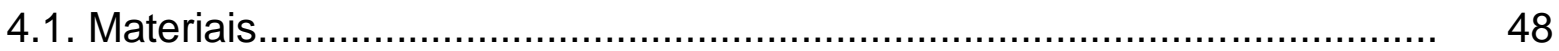

4.1.1. Infraestrutura ..................................................................... 48

4.1.2. Reagentes e solventes................................................................ 48

4.1.3. Equipamentos e demais materiais................................................. 50

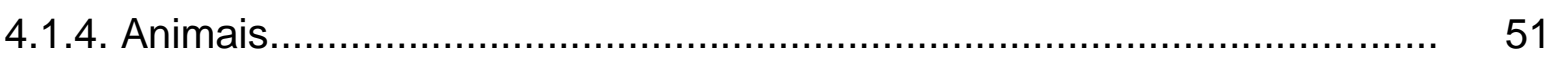

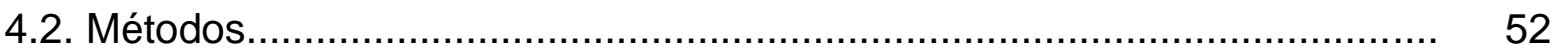


4.2.1. Análise cromatográfica dos conjugados peptídicos.

4.2.2. Marcação dos conjugados peptídicos GLP-1-ßAla-HYNIC e HYNICBAla-Exedin 4 .

4.2.3. Avaliação radioquímica dos conjugados radiomarcados........................ 53

4.2.4. Determinação da lipofilicidade dos produtos radiomarcados.................. 54

4.2.5. Delineamento dos estudos biológicos.......................................... 54

4.2.5.1. Animais controle...........................................................

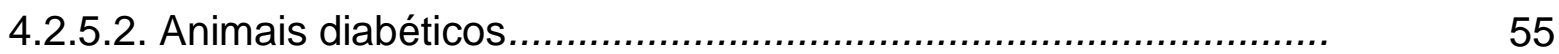

4.2.5.3. Comparação do ganho de peso nos animais sob dietas normocalórica e hiperlipídica...............................................................

4.2.5.4. Animais obesos.................................................................... 5

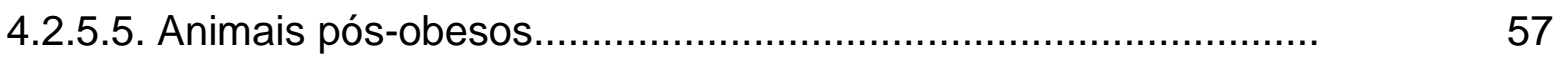

4.2.5.6. Estudo de biodistribuição em animais controle, obesos, diabéticos e pós-obesos.

4.2.5.7. Determinação da ligação às proteínas plasmáticas.

4.2.5.8. Análise histológica de órgãos e tecido.

4.2.5.9. Quantificação ex-vivo por meio de imagens cintilográficas.

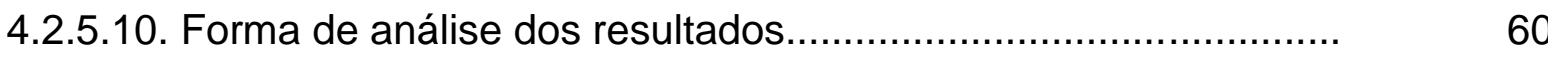

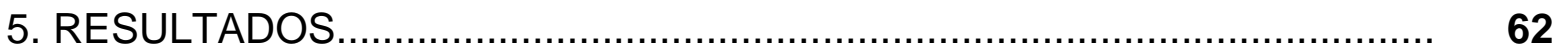

5.1. Análise cromatográfica dos conjugados peptídicos.................................. 62

5.2 Radiomarcação e avaliação radioquímica dos conjugados radiomarcados

5.3. Determinação da lipofilicidade dos produtos radiomarcados.

5.4. Animais diabéticos

5.5. Comparação do ganho de peso nos animais sob dietas normocalórica e hiperlipídica.

5.6. Animais obesos.

5.7. Animais pós-obesos.

5.8. Biodistribuição em camundongos Swiss controle, obesos, diabéticos e pós-obesos.

5.9. Determinação da ligação às proteínas plasmáticas................................... 74

5.10. Análise histológica de órgãos e tecido. 
5.11. Quantificação ex-vivo por meio de imagens cintilográficas................... 76

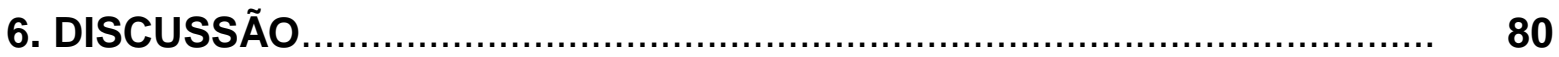

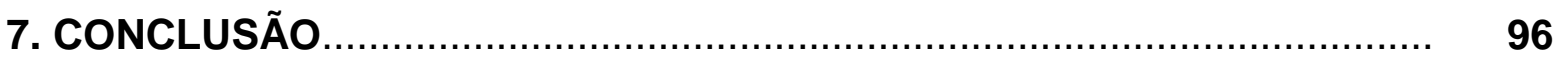

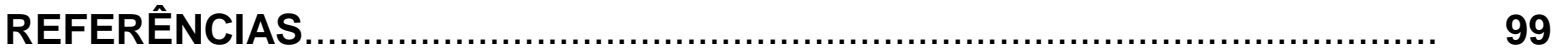

ANEXO 1- Aprovação do Comitê de Ética do IPEN-CNEN/SP ................... 123

ANEXO 2 - Artigo submetido para Periódico Internacional.................... $\quad 125$ 


\section{LISTA DE TABELAS}

Página

TABELA 1 - Nutrientes presentes na ração experimental.

TABELA 2 - Evolução do ganho de peso de camundongos Swiss sob dieta hiperlipídica.

TABELA 3 - Biodistribuição dos radiotraçadores em camundongos Swiss controle (\%Dl/g $\pm \mathrm{DP}, \mathrm{n}=5)$

TABELA 4 - Porcentagem da dose total injetada dos radiomarcados GLP1- $\beta$ Ala-HYNIC- ${ }^{99 m}$ Tc e ${ }^{99 m}$ Tc-HYNIC- $\beta$-Ala-Exedin4 em animais controle para diferentes tempos (\%DI).

TABELA 5 - Biodistribuição do GLP1- $\beta$-Ala-HYNIC- ${ }^{99 m} \mathrm{Tc}$ (\%DI/g) em

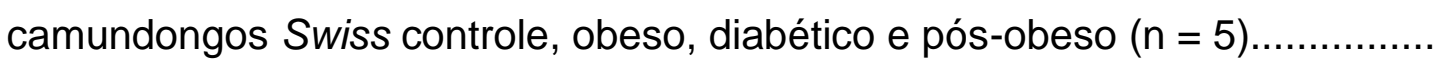

TABELA 6 - Biodistribuição do ${ }^{99 m}$ Tc-HYNIC- $\beta$-Ala-Exedin4 (\%DI/g) em camundongos Swiss controle, obeso, diabético e pós-obeso $(n=5)$.

TABELA 7 - Ligação às proteínas plasmáticas do ${ }^{99 m}$ Tc-HYNIC- $\beta$-AlaExedin4 e GLP1- $\beta$-Ala-HYNIC- ${ }^{99 m}$ Tc $(n=3)$.

TABELA 8 - Quantificação das captações em regiões de interesse (ROI) de camundongos Swiss controle.

TABELA 9 - Quantificação das captações em regiões de interesse (ROI) de camundongos Swiss obesos, diabéticos e pós-obesos para o tempo de 1 hora p.i. 


\section{LISTA DE FIGURAS}

Página

FIGURA 1 - Pâncreas endócrino com as respectivas ilhotas pancreáticas, células beta secretoras de insulina e a captação de glicose por meio da ligação da insulina nas células do tecido muscular.

FIGURA 2 - Esquema simplificado do decaimento de ${ }^{99} \mathrm{Mo} \mathrm{a}{ }^{99 \mathrm{~m}} \mathrm{Tc} \ldots \ldots \ldots \ldots \ldots \ldots . .36$

FIGURA 3 - Obtenção de ${ }^{99 \mathrm{~m}} \mathrm{Tc}$ a partir de geradores ${ }^{99} \mathrm{Mo} /{ }^{99 \mathrm{~m}} \mathrm{Tc} \ldots \ldots \ldots \ldots \ldots \ldots . . . \quad 36$

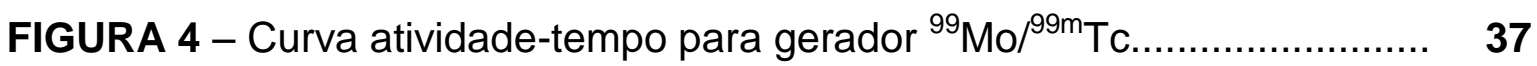

FIGURA 5 - Ilustração esquemática do radiotraçador alvo-específico............. $4 \mathbf{4 1}$

FIGURA 6 - Molécula de HYNIC ..................................................... 42

FIGURA 7 - Estrutura molecular do conjugado peptídico GLP1-HYNIC; (A) GLP1; (B) $\beta$-Ala; (C) HYNIC. Peso Molecular: 3632.

FIGURA 8 - Estrutura molecular do conjugado peptídico HYNIC-Exedin4; (A) HYNIC; (B) $\beta$-Ala; (C) Exedin4. Peso Molecular: 4392,8............................

FIGURA 9 - Cromatograma dos conjugados peptídicos (A) GLP1-HYNIC e (B) HYNIC-Exedin4

FIGURA 10 - Radiocromatograma do (A) ${ }^{99 \mathrm{~m}} \mathrm{TcO}_{4}$; (B) GLP1- $\beta$ ala-HYNIC${ }^{99 \mathrm{~m}} \mathrm{Tc}$; (C) ${ }^{99 \mathrm{~m}}$ Tc-HYNIC-Bala-Exedin4

FIGURA 11 - Valores de glicemia e peso antes e após a administração da aloxana.

FIGURA 12 - Médias dos pesos corporais (inicial e final) dos animais com dietas normocalórica e hiperlipídica.

FIGURA 13 - Aumento de peso absoluto de animais com dieta normocalórica e hiperlipídica

FIGURA 14 - Aumento da porcentagem de peso de animais com dieta normocalórica e hiperlipídica.

FIGURA 15 - Valores de glicemia inicial e final (em mg/dL) após ingestão de $\mathrm{DH}$.

FIGURA 16 - Médias dos pesos corporais (inicial e final) dos animais com dietas hiper e hipolipídica. 
FIGURA 17 - Média da glicemia (em mg/dL) nos animais pós-obesos

FIGURA 18 - Depuração sanguínea dos radiotraçadores GLP1- $\beta$-AlaHYNIC- ${ }^{99 m}$ Tc e ${ }^{99 m}$ Tc-HYNIC- $\beta$-Ala-Exedin4 em camundongos Swiss controle $(n=5) .\left(^{*}\right) p<0,05$

FIGURA 19 - Cortes histológicos do fígado de camundongo Swiss (A) controle; (B) obeso; (C) diabético; (D) pós-obeso, aumento de 20 X...........

FIGURA 20 - Cortes histológicos do pâncreas de camundongo Swiss (A) controle; (B) obeso; (C) diabético; (D) pós-obeso, aumento de 20 X. Seta indica células beta pancreáticas na Ilhota de Langerhans.

FIGURA 21 - Imagens ex vivo nos 4 grupos de animais: controle (A), obeso (B), diabético (C) e pós-obeso (D) para o tempo de 60 min p.i. do GLP1- $\beta$ Ala-HYNIC- ${ }^{99 m}$ Tc

FIGURA 22 - Imagens ex vivo nos 4 grupos de animais: controle (A), obeso (B), diabético (C) e pós-obeso (D) para o tempo de 60 min p.i. do HYNIC- $\beta$ Ala-Exedin4. 


\section{LISTA DE ABREVIATURAS}

GLP-1 = Glucagon-Like-Peptide 1

${ }^{99 \mathrm{~m}} \mathrm{Tc}=$ Tecnécio-99m

$\mathrm{DM}=$ Diabetes Mellitus

DM1 = Diabetes Mellitus 1

DM2 = Diabetes Mellitus 2

DMG $=$ Diabetes Mellitus Gestacional

ATP $=$ Adenosina Trifosfato

GIP = Gastric Inhibitory Polypeptide

$\mathrm{SNC}=$ Sistema Nervoso Central

DPP4 = Enzima Dipeptidil-Peptidase 4

${ }^{99} \mathrm{Mo}=$ Molibdênio-99

HYNIC = 1.6.1. 6-hidrazinonicotinamida

IPEN = Instituto de Pesquisas Energéticas e Nucleares

$\mathrm{PM}=$ Peso Molecular

CLAE = Cromatrografia Líquida de Alta Eficiência 
FOUSP $=$ Faculdade de Odontologia da Universidade de São Paulo

CVAP $=$ Centro Veterinário de Anatomia Patológica

ANOVA = Análise de Variância

$\mathrm{HE}=$ Hematoxicilina - Eosina

$\mathrm{t}_{1 / 2}=$ Tempo de meia-vida

$\mathrm{mg}=$ miligrama

$g$ = grama

$\mathrm{kg}=$ kilograma

$\mathrm{DI} / \mathrm{g}$ = Dose Injetada por grama

$\mathrm{DI}=$ Dose Injetada

$\mathrm{mg} / \mathrm{dl}=$ miligrama por decilitro

$\%=$ porcentagem

$\mathrm{ROI}=$ Regiões de Interesse 


\section{INTRODUÇÃO}

O aumento alarmante nos casos de obesidade em todo o mundo tem gerado grande preocupação e estimulado a comunidade cientifica a realizar pesquisas focadas na busca de alternativas para auxiliar na prevenção e/ou no tratamento dessa condição patológica.

A combinação do diabetes com obesidade tornou-se um desafio da saúde mundial. O diabetes tipo II é caracterizada pelo elevado nível de glicose no sangue no âmbito da resistência à insulina. Mesmo pacientes submetidos à cirurgia bariátrica ou metabólica podem não se curar do diabetes, pois já foi verificado que a produção de insulina nem sempre corresponde à massa beta pancreática (BUTLER e MATVEYENKO, 2008; CNOP et al., 2002), originária nas ilhotas de Langerhans do pâncreas.

As dificuldades impostas pela localização do pâncreas, circundado por órgãos abdominais, a população pequena e dispersa de células beta (ilhotas na faixa de 50 a $500 \mu \mathrm{m}$ de diâmetro) e as indefinições na patogenia das doenças, tornam o diagnóstico clínico das anormalidades geradas pela massa beta ainda bastante limitado. Estudos metabólicos indiretos não refletem a disfunção das células beta, a menos que ocorra uma redução significante delas. Os métodos de diagnóstico ocasionalmente são invasivos, e muitos não são precisos sendo quase sempre realizados após substancial evolução da doença (ISLAM, 2010).

O desenvolvimento de métodos de imagem para o diagnóstico precoce de massa de células beta pancreáticas tem despertado o interesse da comunidade de imagem molecular e de pesquisadores clínicos.

Um monitoramento não invasivo por imagem poderá favorecer o paciente no curso do diabetes para determinação do estágio da doença, para seleção de candidatos a transplante de ilhotas, e em casos de obesos mórbidos submetidos à 
cirurgia bariátrica, para avaliar a massa beta pancreática a luz da resposta glicêmica pós-operatória. Não há ainda disponível um radiotraçador específico para células beta, que as distinga de forma prática e clinicamente aplicável dos outros componentes das ilhotas de Langerhans.

Os hormônios secretados pelo trato gastrointestinal, as incretinas, mais precisamente os análogos do "glucagon-like-peptide 1" (GLP-1), são ligantes promissores para serem radiomarcados com radioisótopos objetivando esta finalidade.

O radioisótopo tecnécio-99m $\left({ }^{99 m} \mathrm{Tc}\right)$ apresenta vantagens de sua utilização devido ao seu fácil manuseio, boas propriedades químicas e radioquímicas, além da sua disponibilidade, favorecendo o desenvolvimento de um radiofármaco com potencial de aplicação na medicina nuclear, em benefício dos pacientes acometidos por estas doenças (MARQUES et al., 2001).

\subsection{Obesidade}

Os estudos envolvendo a obesidade têm-se intensificado nos últimos anos, em função da presença cada vez maior de indivíduos acometidos dessa doença, que ganha contornos de epidemia mundial. O número de indivíduos adultos com sobrepeso vem crescendo mundialmente e já representava em 2008 um bilhão e meio de pessoas, desta população mais de 30\% (200 milhões de homens e quase 300 milhões de mulheres) foram consideradas como obesas (WHO, 2011).

Além de ser, por si só, um problema de saúde pública mundial, a obesidade é fator de risco para diversas doenças como: diabetes melitos tipo 2, doenças cardiovasculares, hipertensão arterial, apnéia obstrutiva do sono, refluxo gastroesofágico, desordens músculo-esqueléticas e variados tipos de câncer (DIBAISE et al., 2008). Por esse motivo, a obesidade se tornou alvo de muitos trabalhos científicos e hoje é extensamente estudada; muitos dos estudos experimentais exigem o emprego de dietas altamente energéticas (HARRIS, 1994; 
CHANG et al., 1990; WOODS et al., 2003; ESTADELLA et al., 2004; DUARTE et al., 2006; LUCAS et al., 1989).

A obesidade é uma doença multifatorial, com baixo grau de inflamação, que envolve fatores genéticos, endócrinos e comportamentais. Dentre os comportamentais, destacam-se a ingestão excessiva de dietas ricas em gorduras e açúcares e o baixo nível de atividade física (MENDONÇA e DOs ANJOS, 2004).

A obesidade é uma doença metabólica, caracterizada pelo ganho de peso excessivo, pelo aumento do tecido adiposo, por modificações no metabolismo dos carboidratos e lipídeos, e pelo surgimento da resistência insulínica e da disfunção autonômica (KAUFMAN et al., 1991; BESKE et al., 2002; FANTUZZI, 2005).

A acumulação excessiva de tecido adiposo deriva de um aporte calórico excessivo e crônico de alimentos ricos em gordura, sal e açúcares, mas baixo em vitaminas minerais e outros micronutrientes (WHO, 2011) em relação ao gasto energético (metabolismo basal, efeito termogênico e atividade física). Nessa acumulação intervêm tanto os fatores sociológicos, as alterações metabólicas e neuroendócrinas, os componentes hereditários, como o estilo de vida e os hábitos alimentares (MARTINEZ e FRUHBECK, 1996; MARQUES-LOPES et al., 2001; CORBALAN et al., 2002). A obesidade ainda apresenta uma forte associação com inúmeras doenças crônicas (BESKE et al., 2002). Pelo menos 2,8 milhões de pessoas morrem a cada ano no mundo, como resultado de excesso de peso ou obesidade (WHO, 2011).

O consumo de ácidos graxos pode afetar o processo inflamatório via modulação da atividade de fatores de transcrição envolvidos na inflamação, como NFKB e PPARY (CALDER et al., 2011). Existe uma interação entre esses fatores de transcrição, visto que o PPARY inibe a ativação do NFKB. Entre os ácidos graxos incluem-se os saturados, monoinsaturados, poli-insaturados e trans, cada um apresentando seu papel na inflamação derivada da obesidade (CALDER et al., 2011).

Estudos in vitro mostraram que os ácidos graxos saturados promovem processo inflamatório (CALDER et al., 2011), com aumento da expressão de IL-6 e 
TNF (AJUWON e SPURLOCK, 2005), de TLR-4 (WEATHERILL et al., 2005) e consequente aumento da ativação de NFKB (AJUWON e SPURLOCK, 2005). Em humanos, a ingestão de ácidos graxos saturados também foi associada à concentração de IL-6, em indivíduos obesos (FERNANDEZ-REAL et al., 2003). Em estudos experimentais, a dieta hiperlipídica rica em gordura saturada causa obesidade, com aumento de peso corporal, adiposidade e marcadores inflamatórios (PEREIRA et al., 2012).

O consumo excessivo de ácidos graxos saturados também é altamente associado com a síndrome metabólica (KENNEDY et al., 2009), que é um conjunto de risco para doenças cardiovasculares e resistência insulínica (que culmina no diabetes melitos tipo 2) relacionado à obesidade, dislipidemias e hipertensão (LIEN e GUYTON, 2008). Além disso, obesidade abdominal, acúmulo ectópico de gordura e esteatose são incluídas nas complicações metabólicas da obesidade (RASOULI e KERN, 2008). De forma geral, o consumo calórico excessivo ocasiona um aumento do acúmulo de triglicerídeos nos adipócitos (hipertrofia) e, em algumas situações, em número (hiperplasia) dos adipócitos, gerando uma disfunção nestes. Os adipócitos hipertrofiados secretam agentes pró-inflamatórios promovendo uma inflamação sistêmica de baixo grau (KENNEDY et al., 2009).

\subsection{Diabetes Mellitus}

O termo Diabetes deriva de uma palavra grega que significa "passando por", e Mellitus deriva da palavra latina que significa "mel" ou "doce". Os relatos sobre o distúrbio dessa patologia podem ser acompanhados até $01^{\circ}$ século d.C., quando Areteu, da Capadócia, descreveu o distúrbio como uma afecção crônica caracterizada por muita sede e urina adocicada e volumosa (HENRY, 2008).

O Diabetes Mellitus (DM) consiste em uma desordem metabólica de etiologia múltipla caracterizada por hiperglicemia crônica que acarreta alterações do metabolismo de carboidratos, gorduras e proteínas resultante de defeitos na ação ou 
secreção da insulina, ou ambos. Os sintomas da hiperglicemia acentuada no paciente diabético incluem poliúria (aumento do volume urinário), polidipsia (aumento da ingestão hídrica), polifagia (aumento da ingestão alimentar) e significativa perda de peso (SILVA et al., 2002; American Diabetes Association, 2011).

O diabetes, se não tratado, pode levar a múltiplas complicações que incluem retinopatia com possíveis danos à visão, nefropatia podendo levar à insuficiência renal, neuropatia periférica com risco de ulcerações no pé e amputações. Pacientes com diabetes têm risco aumentado de incidência de aterosclerose e doença arterial periférica, uma vez que o metabolismo lipídico está alterado (American Diabetes Association, 2011).

O aumento da incidência de diabetes é uma das maiores preocupações atuais em saúde pública, sendo projetado em cálculos epidemiológicos que o número de diabéticos chegue a aproximadamente 330 milhões no ano de 2030, caso não haja intervenções (WILD et al., 2004).

O Diabetes pode ocorrer associado a diversos distúrbios, como doenças pancreáticas, anormalidades endócrinas, gestação ou uso abusivo de fármacos. As formas de diabetes mellitus são basicamente divididas em 3: Diabetes Mellitus tipo I, insulino-dependente; Diabetes Mellitus tipo II, não-insulino-dependente, insulinoresistente e Diabetes Mellitus gestacional (HANSEL e DINTZIS, 2007).

\subsubsection{Diabetes Mellitus Tipo 1 (DM1)}

O DM1, também conhecida como diabetes insulino-dependente geralmente ocorre devido à destruição autoimune das células $\beta$ produtoras de insulina (nas ilhotas pancreáticas), levando a uma deficiência absoluta na produção e liberação de insulina, o que provoca níveis mais altos de glicose sanguínea, com perda da glicose na urina. Além disso, a falta de glicose intracelular muscular e adiposa provoca a metabolização da gordura corporal, resultando na produção de corpos cetônicos e 
produção continuada de glicose no fígado o que agrava muito mais o quadro hiperglicêmico do diabético (HENRY, 2008).

O desenvolvimento do diabetes tipo 1 pode ocorrer de forma rapidamente progressiva, principalmente, em crianças e adolescentes (pico de incidência entre 10 e 14 anos), ou de forma lentamente progressiva, geralmente em adultos, (LADA, latent autoimmune diabetes in adults; doença auto-imune latente em adultos). Esse último tipo de diabetes, embora assemelhando-se clinicamente ao diabetes tipo 1 auto-imune, muitas vezes é erroneamente classificado como tipo 2 pelo seu aparecimento tardio. Estima-se que 5-10\% dos pacientes inicialmente considerados como tendo diabetes tipo 2 podem, de fato, ter LADA.

\subsubsection{Diabetes Mellitus Tipo 2 (DM2)}

O DM2, também conhecida como diabetes não-insulino-dependente, caracteriza-se pela combinação de resistência à ação da insulina e à incapacidade da célula beta em manter uma adequada secreção de insulina (BUTLER et al., 2003).

A resistência à ação da insulina $(\mathrm{RI})$ é uma anormalidade primária e precoce no curso da doença. Esta se caracteriza pela diminuição da habilidade da insulina em estimular a utilização da glicose pelo músculo e pelo tecido adiposo, prejudicando a supressão da lipólise mediada por esse hormônio. A oferta elevada de ácidos graxos livres altera ainda mais o transporte de glicose no músculo esquelético, além de funcionar como potente inibidor da ação da insulina. Os ácidos graxos livres podem também interferir no transporte da insulina através do endotélio capilar. Alguns fatores se relacionam com a expressão da RI, tais como fatores genéticos, raciais, puberdade, obesidade e o peso ao nascer. A transição da resistência insulínica para o DM é determinada principalmente pela incapacidade do pâncreas em aumentar a secreção da insulina adequadamente em resposta à hiperglicemia (GABBAY et al., 2003; MCLELLAN et al., 2007). 
A resistência à ação da insulina no fígado leva ao aumento da produção hepática de glicose. Numa fase inicial, a elevação nos níveis de glicemia é compensada pelo aumento da secreção de insulina, mas, à medida que o processo persiste por períodos prolongados, associa-se um efeito glicotóxico. Entende-se como efeito glicotóxico o aumento da resistência à ação da insulina e diminuição da função da célula beta, devido à hiperglicemia crônica (GABBAY et al., 2003).

O termo tipo 2 é usado para designar uma deficiência relativa de insulina. A administração de insulina nesses casos, quando efetuada, não visa evitar cetoacidose, mas alcançar controle do quadro hiperglicêmico. A maioria dos casos apresenta excesso de peso ou deposição central de gordura. Em geral, mostram evidências de resistência à ação da insulina e o defeito na secreção de insulina manifesta-se pela incapacidade de compensar essa resistência. Em alguns indivíduos, no entanto, a ação da insulina é normal, e o defeito secretor mais intenso.

Essa doença é familiar, mas os defeitos genéticos de base, para a maioria das pessoas acometidas, ainda não foram definidos. Os fatores de risco incluem obesidade, sedentarismo, história familiar, idade avançada, etnia, e histórias de diabetes gestacional, comprometimento do metabolismo da glicose, hipertensão ou dislipidemia (HENRY, 2008).

O diabetes tipo 2 é mais comum do que o tipo 1, perfazendo cerca de 90\% dos casos de diabetes. É uma entidade heterogênea, caracterizada por distúrbios da ação e secreção da insulina, com predomínio de um ou outro componente (WHO, 1999). A etiologia específica deste tipo de diabetes ainda não está claramente estabelecida como no diabetes tipo 1. A destruição auto-imune do pâncreas não está envolvida. Também ao contrário do diabetes tipo 1, a maioria dos pacientes apresenta obesidade (BUTLER et al., 2003).

A relação entre obesidade e diabetes mellitus tipo 2 é bem estabelecida. Indivíduos com sobrepeso ou obesidade têm um aumento significativo do risco de desenvolverem diabetes, risco este cerca de 3 vezes superior ao da população com peso considerado normal. Um estudo de Blackburn (2002), demonstrou que 
aproximadamente $80 \%$ dos indivíduos com diabetes tipo 2 têm sobrepeso, ou são obesos.

A adiposidade central parece estar associada mais frequentemente à resistência à insulina, do que a distribuição centrífuga de gordura (obesidade periférica). O mecanismo pelo qual o acúmulo de gordura intra-abdominal (visceral) causa resistência à insulina não está claro, embora existam hipóteses de que elevadas concentrações de ácidos graxos livres possam estar implicadas no processo. O acúmulo de ácidos graxos livres poderia iniciar uma cascata metabólica, resultando na inibição da enzima fosfofrutoquinase, e no acúmulo de glicose-6fosfato dentro das células musculares, o que desregularia o transporte de glicose (SILVEIRA, 2003).

\subsubsection{Diabetes Mellitus Gestacional (DMG)}

O diabetes gestacional é definido como uma tolerância diminuída à glicose, de graus variados de intensidade, diagnosticado pela primeira vez durante a gestação, podendo ou não persistir após o parto (WHO, 1999). Os fatores de risco associados ao diabetes gestacional são semelhantes aos descritos para o diabetes tipo 2, incluindo outros fatores como idade superior a 25 anos, ganho excessivo de peso na gravidez, deposição central excessiva de gordura corporal, baixa estatura, crescimento fetal excessivo, polidrâmnio (excesso de liquido amniótico), hipertensão ou pré-eclâmpsia na gravidez e antecedentes obstétricos de morte fetal ou neonatal (GROSS et al., 2002; GUVEN et al., 2004).

\subsection{Hormônios secretados pelo pâncreas reguladores de glicose}

O pâncreas é um órgão constituído de dois tipos principais de tecidos: os ácinos que atuam no controle do metabolismo e secretam sulcos digestivos compostos de enzimas digestivas no duodeno como, por exemplo, as enzimas 
amilases, responsáveis pela degradação dos carboidratos e as enzimas lipases que decompõem os triglicerídeos das células adiposas em ácidos graxos e glicerol e as ilhotas pancreáticas ou ilhotas de Langerhans (FIG. 1) que constituem um aglomerado de células $\beta$ (beta) secretoras de insulina, de células $\alpha$ (alfa) secretoras de glucagon, de células $\delta$ (delta) secretoras de somatostatina e de células PP ou $F$ que secretam o polipeptídeo pancreático (FOX, 2007; SKELIN et al., 2010).

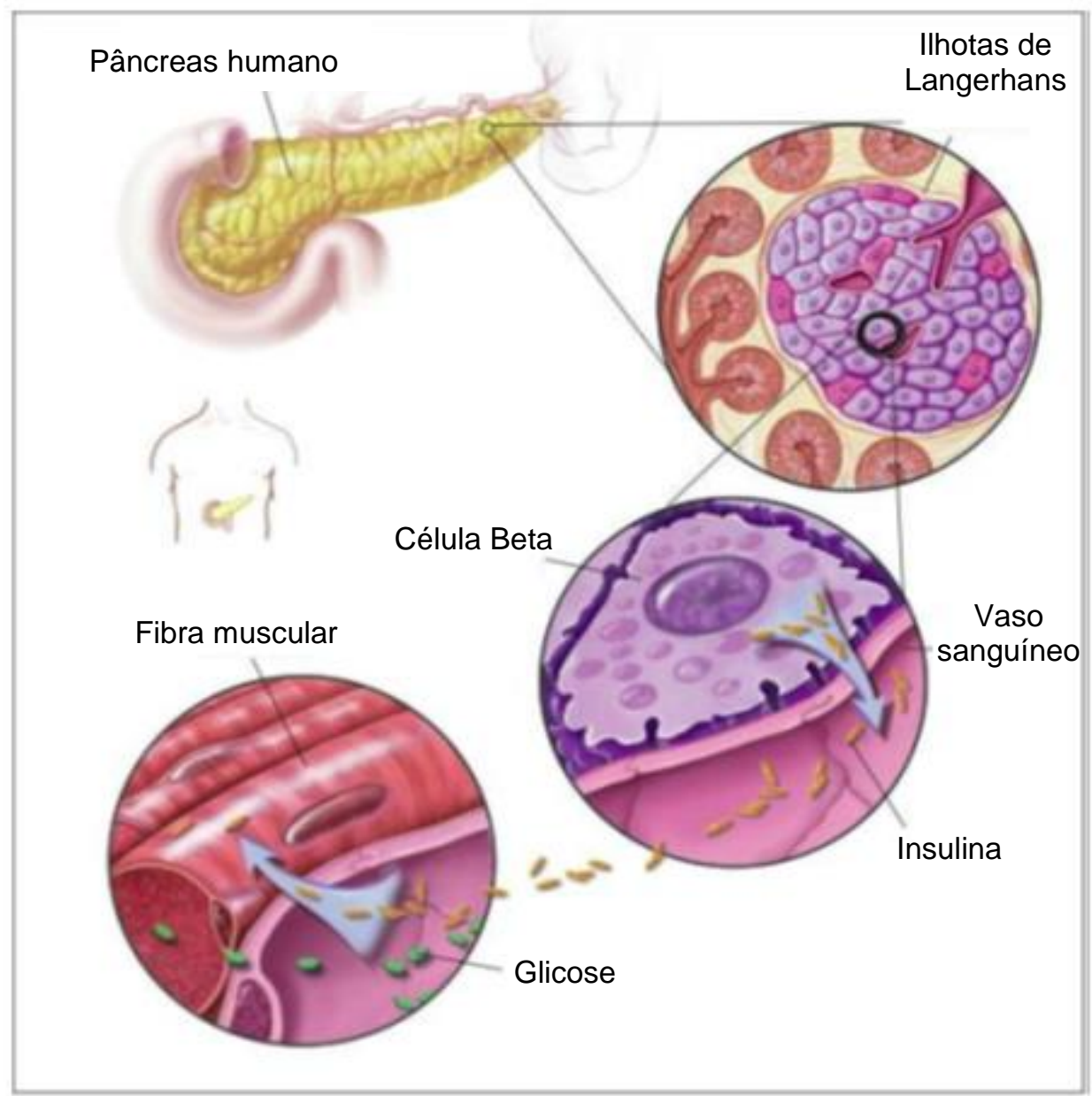

FIGURA 1 - Pâncreas endócrino com as respectivas ilhotas pancreáticas, células beta secretoras de insulina e a captação de glicose por meio da ligação da insulina nas células do tecido muscular (SKELIN et al., 2010).

\subsubsection{Insulina}

A insulina é um hormônio hipoglicemiante que reduz a concentração glicêmica, promovendo a movimentação da glicose para o interior dos tecidos 
musculares, dos tecidos adiposos e do fígado, já que estes são tecidos sensíveis à insulina e necessitam dela para a captação de glicose e consequente produção de energia.

É produzido pelas células beta pancreáticas nas ilhotas de Langerhans, a forma ativa desse hormônio é constituída de duas cadeias polipeptídicas: uma cadeia A e uma cadeia B. A insulina ativa é formada nas células beta a partir da próinsulina. Durante a conversão da pró-insulina em insulina, as enzimas na célula beta efetuam a clivagem da pró-insulina em locais específicos da molécula, formando duas substâncias distintas que são denominadas como: insulina ativa e peptídeo C.

A glicose sanguínea entra na célula beta pancreática por meio de um transportador de glicose, em seguida, ela é fosforilada pela enzima glicoquinase e metabolizada para formar adenosina trifosfato (ATP), uma molécula de energia necessária para fechar os canais de potássio e despolarizar a célula. Essa despolarização provoca a abertura dos canais de cálcio e a secreção de insulina. A secreção de insulina se dá de maneira oscilatória ou pulsátil. Após a exposição à glicose, há uma primeira fase de liberação da insulina pré-formada que fica armazenada (pró-insulina), em seguida, há uma segunda fase onde há a liberação da insulina recém-sintetizada (insulina ativa).

Como mencionado anteriormente, a entrada de glicose nas células dos tecidos musculares e adiposos é insulino-sensível e depende de uma molécula denominada transportador de glicose. Pesquisas consideráveis revelaram basicamente 5 tipos de transportadores de glicose: o GLUT-1, o GLUT-2, o GLUT-3, o GLUT-4 e o GLUT-5 (MACHADO et al., 2006).

O GLUT-1 é o transportador de glicose presente em todos os tecidos, não necessita das ações da insulina e é essencialmente importante no transporte da glicose para o sistema nervoso; o GLUT-2 é o principal transportador de glicose das células beta e das células hepáticas; o GLUT-3 é encontrado em todos os tecidos, considerado também como o maior transportador na superfície neuronal, tem alta afinidade pela glicose e é responsável pelo transporte de glicose do fluído cérebroespinhal para as células nervosas; o GLUT-4 é o chamado transportador de glicose insulino sensível, e seu papel principal é proporcionar a captação de glicose 
mediada por insulina em tecidos adiposos e musculares (que são os tecidos que expressam especificamente a proteína transportadora GLUT-4); e por fim o GLUT-5 é o transportador que está presente na borda das células intestinais, e é também o transportador específico da frutose (MACHADO et al., 2006).

\subsubsection{Glucagon}

O glucagon é um hormônio hiperglicemiante e da mesma maneira que a insulina, a sua liberação é regulada pela glicose, porém, a diferença entre eles é que o glucagon é secretado quando os níveis plasmáticos de glicose estão muito baixos diferentemente da insulina que é secretada quando o nível plasmático de glicose está muito elevado. O efeito mais significativo do glucagon é a sua capacidade de estimular a hidrolise do glicogênio hepático (glicogenólise), como meio de elevar a glicose sanguínea. O glucagon também estimula a hidrólise da gordura armazenada (lipólise) e a consequente liberação de ácidos graxos livres no sangue (FOX, 2007). A redução da concentração de glicose plasmática em nível hipoglicêmico produz o aumento imediato na secreção do glucagon, os níveis de glucagon também aumentam durante exercícios vigorosos, como meio de impedir a redução da glicose sanguínea (GUVEN et al., 2004).

O glucagon é um dos hormônios que ajudam a manter a homeostasia durante os períodos de jejum, os portadores de Diabetes tipo 1 (principalmente aqueles que possuem a doença há mais de 5 anos), com o tempo, apresentam deficiência progressiva desse hormônio, essa deficiência resulta em flutuações glicêmicas aumentadas e em dificuldade de recuperação em uma hipoglicemia (HENRY, 2008). Além disso, a produção e liberação de adrenalina, acetilcolina, cortisol e hormônio do crescimento (que são os hormônios contrarreguladores), também pode ser comprometida por falta de secreção do glucagon. A deficiência na secreção desses hormônios dificulta a recuperação dos níveis plasmáticos de glicose e provocam a ausência dos sinais e sintomas autonômicos da hipoglicemia, dessa forma, a percepção clínica dos quadros hipoglicêmicos somente acontecem pelos sinais neuroglicopênicos, ou seja, quando os níveis de glicose estão realmente baixos (GROSSI et al., 2007). 


\subsubsection{Somatostatina}

A somatostatina foi primeiramente considerada um hormônio do hipotálamo capaz de inibir a secreção do hormônio do crescimento, porém a descoberta da somatostatina nas ilhotas de Langerhans imediatamente induziu novas investigações sobre sua função no pâncreas endócrino.

O efeito fisiológico do peptídeo pancreático ainda é desconhecido, mas alguns estudos estão descobrindo que ele pode estimular a motilidade gastrointestinal (HENRY, 2008; SKELIN et al., 2010).

O hormônio somatostatina é secretado pelas células $\delta$ (delta) e constituem cerca de $5 \%$ a $10 \%$ das células das ilhotas pancreáticas. A somatostatina inibe hormônios hipofisários, gastrointestinais e pancreáticos após a ingestão de alimentos, além disso, possui funções neuroendócrinas (HENRY, 2008). Um dos efeitos da somatostatina é aumentar o período no qual o alimento é absorvido para o sangue, também é liberada para inibir a secreção de insulina e glucagon, tem-se que ela aumenta o uso pelos tecidos dos nutrientes absorvidos. Entretanto não se sabe a real influência endócrina da somatostatina e raramente ela é quantificada na prática clínica (GUVEN et al., 2004).

\subsection{Incretinas}

As incretinas são hormônios polipeptídicos produzidos no trato gastrointestinal e secretados durante a absorção de nutrientes, que agem sobre as células beta e aumentam a secreção de insulina. O conceito incretina foi criado quando se observou que a secreção de insulina em resposta à glicose administrada por via oral é maior do que a secreção de insulina em resposta à glicose administrada por via intravenosa, mesmo quando as concentrações de glicemia são semelhantes. Esse efeito otimiza a resposta de insulina durante as refeições e limita a variação da glicemia pós-prandial (MCINTYRE et al., 1965). 
Existem dois hormônios principais: o GIP (do inglês gastric inhibitory polypeptide) e o GLP-1 (do inglês glucagonlike peptide-1).

A primeira incretina identificada foi chamada de GIP, devido a sua capacidade de inibir a secreção ácida do estômago de cães. Posteriormente, o uso de preparações mais puras demonstrou que este peptídeo tem a capacidade de estimular a secreção de insulina em animais e em seres humanos e passou a ser denominado glucose dependente insulinotropic polypeptide (XU et al., 2007).

O GIP é produzido pelas células $K$ do duodeno e jejuno proximal, em resposta à ingestão de nutrientes, principalmente lipídeos e glicose, e exerce suas ações quando se liga ao seu receptor (GIPR). O GIPR é um receptor que contém sete alças transmembrânicas associado à proteína $G$ e é expresso em diversos tecidos, dentre eles o pâncreas, estômago, intestino delgado, tecido adiposo, coração e diversas regiões do sistema nervoso central (SNC) (BAGGIO e DRUCKER, 2007). Após ser liberado pelas células enteroendócrinas, o GIP se liga a receptores específicos na célula beta pancreática e estimula a secreção de insulina. O GIP também estimula a transcrição do gene da insulina, assim como a expressão de sensores de glicose nas células beta. Ainda no pâncreas, o GIP inibe a apoptose e estimula a proliferação destas células. Além disso, o mesmo é inativado na circulação sanguínea pela ação da enzima proteolítica dipeptidil-peptidase 4 (DPP-4) (DEACON et al., 1995).

O GLP-1 é clivado do pró- glucagon intestinal e secretado das células $L$ do íleo e do cólon, depois da ingestão oral de nutrientes e é rapidamente inativado através da clivagem pela enzima dipeptidil-peptidase 4 (DPP-4) (CHACRA, 2006). Ele atua inibindo a secreção de glucagon, retarda o esvaziamento gástrico e funciona como um regulador da saciedade levando a uma diminuição da glicose circulante. (SCHWARTZ et al., 1996, FLINT et al., 1998, RAYNER et al., 2001). Estudos in vivo não em humanos e estudos in vitro relatam ainda que ele promove a proliferação das células beta e reduz a apoptose (DACHICOURT et al., 1997, FARILLA et al., 2002).

O GLP-1 é o mais importante na patogenia do Diabetes Mellitus 2 (TAMBASCIA et al., 2007). Embora as incretinas sejam liberadas após o consumo 
de nutrientes, as refeições que contém carboidratos e lipídios são as que mais estimulam a secreção da GIP. As incretinas desempenham um papel importante na modulação da resposta das ilhotas de Langerhans e potencializam a secreção de insulina pelas células beta pancreáticas decorrente do aumento dos níveis de glicemia após ingestão de alimentos (ARODA e HENRY, 2004).

Em pessoas saudáveis $70 \%$ da secreção de insulina estimulada pela ingestão de glicose ocorrem através da liberação das incretinas. A denominação "efeito incretina" se refere a um aumento da resposta de insulina à glicose, e este efeito encontra-se reduzido ou ausente em pacientes com DM2 (GERICH, 2010, apud LIMA, 2012).

O efeito incretina transforma as células endócrinas do intestino em sistema de controle secundário ao metabolismo da glicose (PREITNER et al., 2004). Este efeito corresponde a aproximadamente 50 a $70 \%$ da insulina total secretada após sobrecarga oral de glicose (BAGGIO e DRUCKER, 2007; GAUTIER et al., 2008). A diminuição do efeito incretina causada pela redução na secreção e/ou por insensibilidade das células $\beta$ à ação insulinotrópica das incretinas e que, consequentemente diminui a secreção de insulina, pode ser um dos fatores que contribuem para o desenvolvimento do DM2.

Os pacientes com DM2 possuem resposta insulinotrópica deficiente à administração exógena de GIP, no entanto possuem resposta preservada ao GLP-1 exógeno. Isso nos mostra que os diabéticos tipo 2 têm baixas concentrações de GLP-1 endógeno mas respondem ao GLP-1 exógeno secretando insulina. Esse tipo de confirmação sustenta o potencial tratamento com GLP-1 em pacientes DM2 (CHACRA, 2006).

O defeito das incretinas no DM2 parece ser decorrente de duas causas (HOLST e GROMADA, 2004): redução da secreção de GLP-1 e efeitos insulinotrópico excessivamente deteriorados do GIP. 
O efeito prejudicado das incretinas leva a uma redução significativa da secreção de insulina estimulada pela ingestão de nutrientes, gerando uma hiperglicemia pós-prandial considerável (ARODA e HENRY, 2004).

A meia-vida do GLP-1 é de menos de 3 minutos, sendo a enzima dipeptidil peptidase IV (DPP-IV) a principal responsável por seu catabolismo. O conhecimento de que o GLP-1 é rapidamente degradado por essa aminopeptidase, resultou na busca e descoberta de alguns inibidores, como os compostos vildagliptina (Galvus $\AA^{\circledR}$, Novartis) e sitagliptina (Januvia ${ }^{\circledR}$, Merck Sharp \& Dohme).

Partindo de observações de que o veneno do monstro de Gila (Heloderma suspectum) estimula in vitro a secreção pancreática de enzimas chegou-se à descoberta, neste veneno, de peptídeos estruturalmente análogos ao peptídeo intestinal vasoativo (VIP) - ação hipotensora - e à secretina, ou seja, os peptídeos helospectina-1, helospectina-2 e helodermina. No mesmo veneno, o peptídeo exedin-4 foi isolado e mostrou-se agonista do GLP-1, possuindo as mesmas ações do GLP-1 endógeno, com a vantagem de ser resistente à degradação enzimática, o que proporciona uma meia-vida maior que a observada para o GLP-1. Esta característica prolonga os efeitos anti-diabetogênicos desse peptídeo (GIORGINO et al., 2006).

Para o novo modelo de tratamento baseado nas incretinas foram criados os incretinomiméticos que são os análogos e os agonistas do GLP-1, os quais apresentam ações farmacológicas semelhantes às do próprio GLP-1 (SOCIEDADE BRASILEIRA DE DIABETES, 2007). O análogo do GLP-1 é a liraglutida (Victoza®, Novo Nordisk) e o agonista do GLP-1 é a exenatida (Byetta®, Eli Lilly Pharmaceuticals) (AMORI et al., 2007).

Outra estratégia importante é aumentar o tempo de meia-vida do GLP-1 endógeno que é rapidamente degradado pelas enzimas DDP-4 e NEP (endopeptidase neutra), enzimas que estão presentes nas células das maiorias dos tecidos incluindo células do aparelho gastrointestinal, fígado, rins, linfócitos e células endoteliais. (DRUCKER e NAUCK, 2006). Sendo assim, foi criada também uma forma de aumentar o efeito da incretina através da inativação da enzima que degrada o GLP-1, a DPP-4, consequentemente aumentando o tempo de ação do 
próprio GLP-1 endógeno. Esses medicamentos são conhecidos como inibidores da DPP-4. São as gliptinas, Sitagliptina (Januvia®), Vildagliptina (Galvus®), Linagliptina (Trayenta®), Saxagliptina (Onglyza®) (GREEN et al., 2006, RUSSEL-JONES e GOUGH, 2012; VILSBOLL e GARBER, 2012). Porém os níveis de GLP-1 endógeno obtidos pela utilização de inibidores da DPP-4 são menores do que aqueles fornecidos pela administração farmacológica de GLP-1 (BARNETT, 2009).

Sendo assim, a fim de utilizar o GLP-1 para terapia de diabetes tipo 2, há duas opções atualmente disponíveis:

1. Agonistas de receptores de GLP-1 (ou GLP-1 miméticos) como compostos injetáveis;

2. E inibidores da DPP-4 (ou potenciadores das incretinas) como substâncias ativas oralmente (DRUCKER e NAUCK, 2006).

Uma das principais diferenças entre o GLP-1 mimético e inibidores DPP-4 é o aumento modesto nos níveis de GLP-1 endógeno e a ativação dos receptores do GLP-1. Como a via neural parece ser mais importante do que a rota endócrina para estímulo da secreção de insulina, e requer menores níveis de GLP-1, este aumento modesto poderia ser suficiente para induzir a maioria das ações mediadas pelo GLP1. Tais ações podem ser atribuídas à estimulação da sinalização da via WNT, através dos receptores do GLP-1, também presentes nas células beta.

O exendin-4 é um peptídeo natural de 39 aminoácidos, presente na glândula salivar do lagarto monstro de Gila (Heloderma suspectum). O peptídeo tem efeitos potentes na homeostase da glicose em mamíferos. Os efeitos do exedin-4 são atribuíveis à semelhança na sequência de aminoácidos com o GLP-1, que é liberado pelas células $L$ intestinais em resposta à ingestão de alimentos.

A exenatida, forma sintética do exedin-4, é um agente largamente utilizado para o tratamento dos pacientes diabéticos, que induz redução de peso, atua na redução da glicemia em jejum e pós-prandial, reduz HbA1c, e pode estimular a proliferação das células beta. 
Foi o primeiro agonista de GLP-1 aprovado para o tratamento do DM2 em combinação com metformina e / ou uma sulfonilureia em doentes que não conseguiram alcançar os objetivos terapêuticos com esta medicação oral (GALLWITZ, 2010). Ela melhora o controle glicêmico principalmente por redução da hiperglicemia pós-prandial, com uma modesta redução nos níveis de glicemia de jejum. Uma característica proeminente de DM2 é uma redução dramática na primeira fase de secreção de insulina. (FEHSE et al., 2005).

O uso concomitante de exenatida com insulina não tem sido estudado $e$, portanto, não pode ser recomendada. A exenatida é administrada por via subcutânea, através de um dispositivo de aplicação (caneta); a dose inicial é de $5 \mu \mathrm{g}$ duas vezes por dia, administrado dentro de 60 minutos antes do café da manhã e do jantar. A exenatida produz resultados consistentes e significativos na perda de peso e auxilia a redução da HbA1c (AMORI et al., 2007).

\subsection{Radioisótopo tecnécio - $99 \mathrm{~m}\left({ }^{99 \mathrm{~m}} \mathrm{Tc}\right)$}

\subsubsection{Histórico}

Radionuclídeos são núcleos atômicos instáveis que se estabilizam através de seu decaimento radioativo. Dentre os mais de 3000 radionuclídeos existentes, apenas cerca de 30 são rotineiramente usados em atividades de Medicina Nuclear, sendo a maioria artificial, gerada a partir de irradiação em reatores nucleares, cíclotrons ou em aceleradores de larga escala (HAMOUDEH et al., 2008).

O radionuclídeo ligado à molécula dá a característica diagnóstica ou terapêutica ao radiofármaco. Os radioisótopos usados em Medicina Nuclear com propósito diagnóstico são essencialmente os emissores de radiação gama e pósitrons. Para uso diagnóstico, os radioisótopos emitem radiação eletromagnética que penetra o tecido e é detectado externamente, promovendo a aquisição de imagens. Raios gama ou raios $\mathrm{X}$ distribuem suas energias uniformemente através do 
tecido, podendo atravessar tecidos bastante espessos (WEINER e THAKUR, 2005). O progresso em técnicas de diagnóstico em Medicina Nuclear, desde a primeira aplicação do tecnécio-99 meta estável ( $\left.{ }^{99 m} \mathrm{Tc}\right)$ em 1960, é verdadeiramente notável (BANERJEE et al., 2001).

O elemento químico tecnécio não é encontrado na crosta terrestre em abundância, pois o mesmo não é gerado continuamente pela reação ou decomposição de outros elementos presentes no planeta. Sabe-se que diminutas amostras de tecnécio foram encontradas em rochas, provavelmente devido aos raios cósmicos que bombardearam a Terra (WEEKS, 1993).

O tecnécio foi descoberto em 1925 pelos cientistas Noddack, Tacke e Berg, os quais o chamaram, inicialmente, de massarium. Eles se basearam nos espectros e emissão de raios $X$ obtidos com concentrados de gangas de vários minerais, como por exemplo, a columbita (WEEKS, 1993). O nome "tecnécio" foi originado do grego technetos que significa "artificial" e empregado, primeiramente, por Paneth (1947), justamente por ser o primeiro elemento radioativo produzido pelo homem (BANERJEE et al., 2001).

Somente em 1937, na Itália, os cientistas Perrier e Segré isolaram e estudaram este elemento, o qual foi extraído de uma placa defletora de molibdênio usada em cíclotron, e somente a partir de 1970, o radioisótopo ${ }^{99 \mathrm{~m}}$ Tc começou a ser empregado com frequência na Medicina Nuclear (JURISSON e LYDON, 1999).

\subsubsection{Propriedades químicas, físicas e nucleares do ${ }^{99 m} T c$}

O tecnécio é um metal de transição de número atômico 43, situado no Grupo 7 da Tabela Periódica. Possui uma configuração eletrônica 4d55s2, fornecendo diversas oportunidades para a formação de complexos com um vasto número de diferentes ligantes (BANERJEE et al., 2005; DEUTSCH et al., 1983).

Tal fato deve-se principalmente à sua química redox, que apesar de fornecer múltiplas oportunidades relativas à modificação estrutural e às propriedades dos complexos formados através de uma adequada escolha do sistema quelante, 
torna difícil o controle dos seus estados de oxidação e a labilidade dos complexos formados (JURISSON e LYDON, 1999; LIU e EDWARDS, 1999; LIU, 2004)

As reações de complexação podem ser realizadas com vários tipos de agentes quelantes, cujos números de coordenação podem variar de 4 a 9 . Entre os diversos tipos de agentes quelantes vale a pena mencionar os que contém os núcleos $\left({ }^{99 \mathrm{~m}} \mathrm{TcO}\right)^{3+}$ e $\left({ }^{99 \mathrm{~m}} \mathrm{TcO}_{2}\right)^{+}$.

Os números do estado de oxidação do tecnécio variam de $-1 \mathrm{a}+7$, e seus complexos de coordenação podem se arranjar de diversas formas (KHARISOV e MENDES-ROJAS, 2001). O tecnécio possui 21 isótopos, os quais apresentam número de massa que varia entre 90 e 110, e tempo de meia vida física ( $\left.\mathrm{t}_{1 / 2}\right)$ que varia entre 0,86 segundos e 2,6 $\times 10^{6}$ anos. Nenhum destes isótopos é estável e o isótopo ${ }^{99 \mathrm{~m}} \mathrm{Tc}$ é o que apresenta as melhores propriedades físicas e químicas para a detecção externa (FAINTUCH, 1997).

A ampla utilização de radiofármacos com ${ }^{99 \mathrm{~m}} \mathrm{Tc}$ está relacionada a diversos fatores, tais como o seu favorável modo de decaimento que inclui a emissão-y, de energia monocromática de $140 \mathrm{KeV}$, ideal para aquisição de imagens cintilográficas. A esta característica ideal somam-se o curto t1/2 de 6,02 horas, acompanhado por um relativamente baixo nível de radiação não penetrante, bem como, a eficiente separação do radionuclídeo "pai", molibdênio-99 $\left({ }^{99} \mathrm{Mo}\right)$, através do sistema de geradores ${ }^{99} \mathrm{Mo} /{ }^{99 \mathrm{~m}} \mathrm{Tc}$, primeiramente desenvolvido no Laboratório Nacional de Brookhaven em 1958 por Tucker e Green(DEUTSCH et al., 1983; ECKLEMAN,1998; WELCH e REDVANLY, 2003; LIU, 2004).

Este gerador pode ser produzido utilizando três métodos químicos diferentes, a saber: cromatográfico, sublimação e extração por solventes. O procedimento mais utilizado é o cromatográfico, baseado em sistema de alumina com ${ }^{99}$ Mo de produto de fissão, justamente por apresentar um excelente custobenefício (BOYD, 1982).

No gerador de ${ }^{99} \mathrm{Mo} /{ }^{99 \mathrm{~m}} \mathrm{Tc}$, o molibdato $\left({ }^{99} \mathrm{MoO}_{4}{ }^{2-}\right)$ é absorvido em uma coluna de alumina e o ${ }^{99 \mathrm{~m}} \mathrm{Tc}$ é formado pelo decaimento do ${ }^{99} \mathrm{Mo}$, conforme mostra a FIG. 2. 


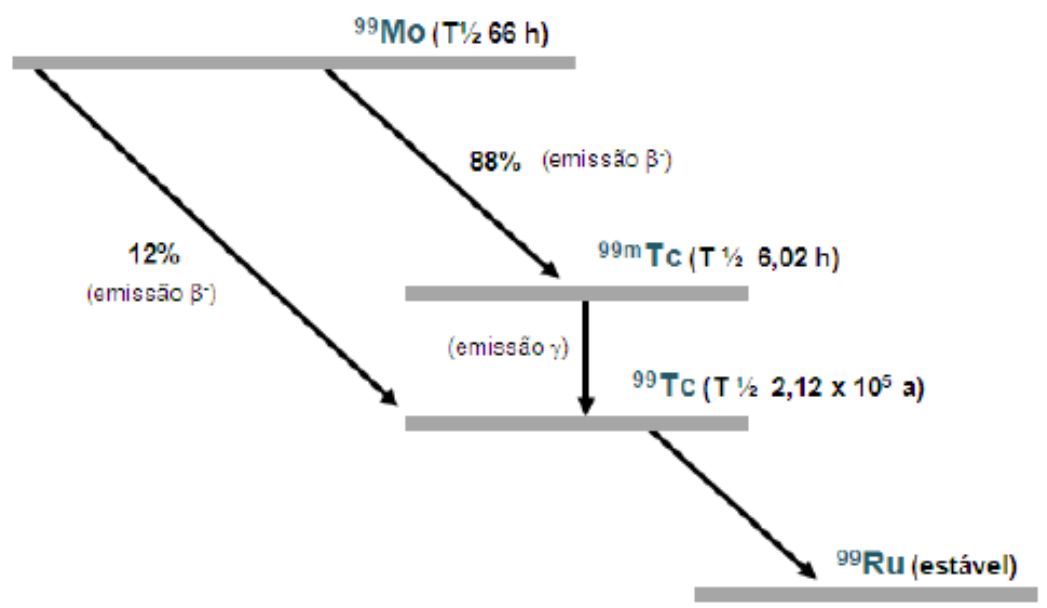

FIGURA 2 - Esquema simplificado do decaimento de ${ }^{99} \mathrm{Mo}$ a ${ }^{99 \mathrm{~m}} \mathrm{Tc}$ (MARQUES et al., 2001).

O ${ }^{99 m}$ Tc produzido a partir de um gerador de ${ }^{99}$ Mo é eluído em solução salina na forma de $\mathrm{Na}^{99 \mathrm{~m}} \mathrm{TcO}_{4}$ (pertecnetato de sódio) e recolhido em frasco a vácuo, enquanto o molibdato fica retido na coluna (FIG. 3). Esta espécie de ${ }^{99 \mathrm{~m}} \mathrm{Tc}$ possui estado de oxidação VII, no qual o ${ }^{99 \mathrm{~m}}$ Tc é praticamente inerte, razão pela qual tem que ser reduzido. O novo estado de oxidação vai depender do agente redutor, o agente quelante e as condições da reação.

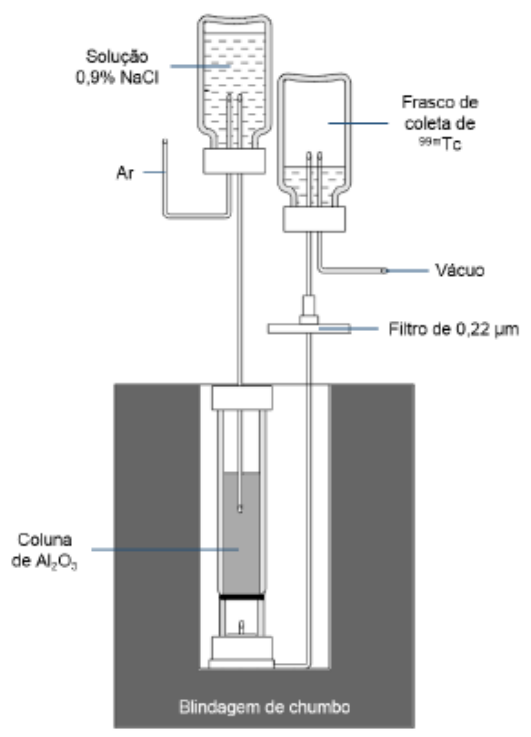

FIGURA 3 - Obtenção de ${ }^{99 m}$ Tc a partir de geradores ${ }^{99} \mathrm{Mo} /{ }^{99 m} \mathrm{Tc}(\mathrm{SAHA}, 2010)$. 
A FIG. 4 apresenta uma típica curva da atividade de ${ }^{99 \mathrm{~m}} \mathrm{Tc}$ após eluição do gerador ${ }^{99} \mathrm{Mo} /{ }^{99 \mathrm{~m}} \mathrm{Tc}$, em relação ao decaimento de ${ }^{99} \mathrm{Mo}$. É possível observar que a atividade de ${ }^{99 \mathrm{~m}} \mathrm{Tc}$ aumenta até alcançar um estado de equilíbrio transiente com ${ }^{99} \mathrm{Mo}$, a partir do qual ambos os radionuclídeos decaem com uma única meia-vida aparente. Ou seja, quando em equilíbrio, a razão entre a atividade de ${ }^{99} \mathrm{Mo}$ e a de ${ }^{99 \mathrm{~m}} \mathrm{Tc}$ permanece constante ao longo do tempo. Além disso, nota-se também que a radioatividade de ${ }^{99 \mathrm{~m}} \mathrm{Tc}$ alcança o valor máximo em aproximadamente quatro meiavidas ( 23 h) após a última eluição, o que torna viável a eluição diária do gerador (Zolle, 2007).

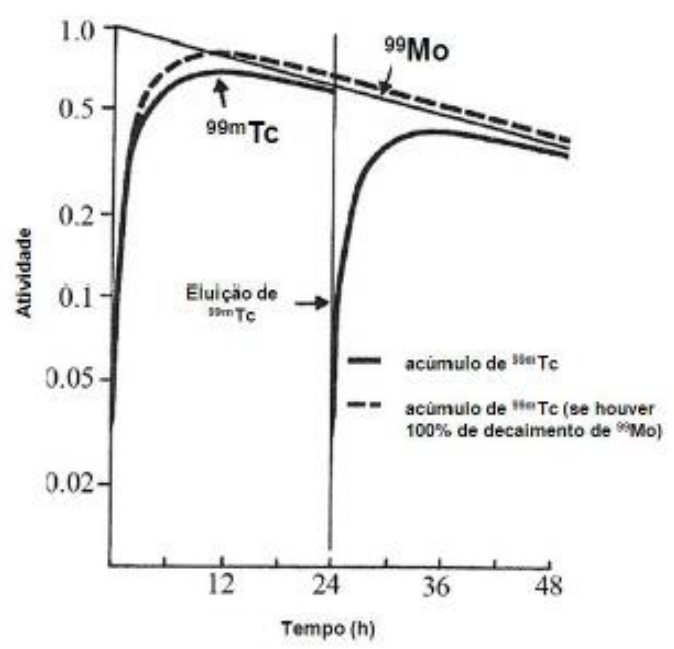

FIGURA 4 - Curva atividade-tempo para gerador ${ }^{99} \mathrm{Mo} /{ }^{99 \mathrm{~m}} \mathrm{Tc}$ (Green, 2012).

A radiomarcação relativamente fácil dos seus componentes e a ausência de necessidade de purificação torna esses tipos de traçadores adequados para produção em massa, em forma de kits, que podem ser distribuídos e usados em hospitais e clínicas onde haja um gerador presente (EBENHAN et al., 2014).

Uma característica fundamental que devem possuir os radiofármacos de ${ }^{99 \mathrm{~m}} \mathrm{~T}$ c é uma ligação estável do radionuclídeo à biomolécula. A dissociação in vivo do radiometal pode conduzir a uma imagem de baixa qualidade, uma desnecessária exposição à radiação para o paciente e uma imprecisa interpretação da imagem (BANERJEE et al., 2005). 
Os radiofármacos contendo tecnécio-99m tornaram-se importantes ferramentas para o diagnóstico de várias doenças. Dentre elas, pode-se destacar a localização de lesões cerebrais, estudos da tireóide, tumores, glândulas salivares, cintilografia gástrica, etc (MARQUES et al., 2001; FAINTUCH et al., 2005).

\subsubsection{Marcação de biomoléculas $\mathrm{com}^{99 m} \mathrm{Tc}$}

Existem várias técnicas de marcação de biomoléculas com tecnécio desenvolvidas. A estratégia de marcação deve ser selecionada de forma apropriada e otimizada visando uma alta estabilidade do produto radiomarcado, propriedade hidrofílica e baixa ligação às proteínas plasmáticas.

Os métodos de marcação de biomoléculas com o radioisótopo ${ }^{99 m} \mathrm{Tc}$ podem ser agrupados, basicamente, em tres formas: 1) marcação direta; 2) prémarcação indireta; 3) pós-marcação indireta.

A marcação direta utiliza um agente redutor para reduzir o ${ }^{99 m}$ Tc ao mesmo tempo em que se reduzem as pontes dissulfetos da biomolécula, originando dois grupos tióis que se ligam ao radionuclídeo.

Esta técnica pode ser utilizada em marcações com proteínas ou peptídeos que apresentam pontes de enxofre. No entanto, o método apresenta algumas limitações, como por exemplo: a marcação não é específica, ou seja, apresenta baixo controle do sítio de ligação do tecnécio deixando a sua geometria desconhecida; os complexos formados são instáveis in vivo; e as quebras das pontes de enxofre podem alterar a estrutura da biomolécula e impedir a sua integridade biológica (BLOK et al., 1999). Esta técnica não é muito adequada para radiomarcação de biomoléculas pequenas, sendo a sua principal vantagem é a fácil execução (BLOK et al., 1999; JURISSON, 2002). Ela foi muito empregada na década de 90 para a marcação de peptídeos e anticorpos com Tc(V) (FICHNA e JANECKA, 2003). 
$\mathrm{Na}$ marcação indireta faz-se necessário o uso de ligantes, chamados também de agentes quelantes bifuncionais, que são moléculas que contêm grupos funcionais capazes de unirem-se ao íon metálico $\left({ }^{99 \mathrm{~m}} \mathrm{Tc}\right.$ ) formando um complexo.

Na pré-marcação indireta, o tecnécio é ligado, inicialmente, ao quelante para somente depois se ligar e complexar a biomolécula. A técnica utiliza precursores, e vem sendo muito empregada devido ao advento dos experimentos de Alberto et al. (1995), que utilizaram ${ }^{99 \mathrm{~m}} \mathrm{Tc}$ como núcleo de complexo organometálico carbonílico.

As vantagens do emprego desta técnica são a boa definição do processo químico; o fácil controle reacional; e a garantia que o radionuclídeo é quelado diretamente pelo agente sem afetar a estrutura da biomolécula, já que a marcação e a etapa de complexação são separadas (FICHNA e JANECKA, 2003). No entanto, as múltiplas etapas sintéticas representam um problema à sua aplicação nas radiofarmácias hospitalares.

Na pós-marcação indireta a biomolécula é previamente conjugada ao quelante bifuncional para somente depois realizar a marcação e complexação com o radionuclídeo. Esta é a técnica mais utilizada na produção de radiofármacos, justamente por não utilizar o radioisótopo no primeiro momento da síntese e também por apresentar uma química bem definida e de relativa simplicidade (FICHNA e JANECKA, 2003; LIU, 2004; LIU, 2008)

\subsection{Agente quelante bifuncional}

O agente quelante bifuncional apresenta dois propósitos: a ligação ao radionuclídeo de maneira segura sem dissociação in vivo e a formação de um apêndice estrutural para ligação à biomolécula, mantendo a máxima integridade biomolecular. A extremidade que se liga ao marcador deve possuir elevada estabilidade cinética sob condições biológicas, enquanto a outra terminação do 
quelante bifuncional permite a ligação covalente à molécula biológica (BANERJEE et al., 2005, PRICE e ORVIG, 2014).

Um ligante bifuncional ideal é aquele que forma complexos de ${ }^{99 m}$ Tc com altos rendimentos e a baixas concentrações do conjugado - biomolécula. Para atingir este objetivo, o conjugado deve seletivamente estabilizar um intermediário ou reduzir o estado de oxidação do ${ }^{99 \mathrm{~m}} \mathrm{Tc}$, de maneira que o mesmo não sofra reações redox. As mudanças de estados de oxidação frequentemente acontecem com subsequente transquelação do complexo ${ }^{99 \mathrm{~m}} \mathrm{Tc}$-conjugado-biomolécula aos quelantes nativos em sistemas biológicos. Sua estereoquímica é importante quando da síntese de radiofármacos para receptores específicos. Quando utilizados para formar complexos com ${ }^{99 m} \mathrm{Tc}$, apresentam estabilidade termodinâmica e um número bastante reduzido de formação de isômeros (KOWALSKY e FALEN, 2004).

Um dos agentes quelantes utilizados primeiramente foi 0 ácido dietilenotriamino pentaacético (DTPA), porém essencialmente para os radioisótopos ${ }^{111}$ In, ${ }^{90} \mathrm{Y}$ e ${ }^{99} \mathrm{Tc}$ (KOWALSKY e FALEN, 2004). Geralmente, os agentes quelantes de escolha para marcações com ${ }^{99 \mathrm{~m}} \mathrm{Tc} /{ }^{188} \mathrm{Re}$ foram do tipo triaminotiol $\left(\mathrm{N}_{3} \mathrm{~S}\right)$ (KASINA et al., 1998), diaminoditióis $\left(\mathrm{N}_{2} \mathrm{~S}_{2}\right)$ (LIU e EDWARS, 1999) e mercaptoacetiltriglicina $\left(\mathrm{MAG}_{3}\right)(\mathrm{GANO}$ et al., 1998).

Outro agente, o 6-hidrazinonicotinamida (HYNIC), tem sido empregado nas radiomarcações de biomoléculas com ${ }^{99 \mathrm{~m}} \mathrm{Tc} /{ }^{188} \mathrm{Re}$ apresentando resultados promissores por causa de sua alta eficiência de marcação especialmente com análogos da somatostatina (PLACHCINSKA et al., 2004) e oligonucleotídeos antisenso (ZHANG et al., 2000).

$\mathrm{Na}$ FIG. 5 é possível observar uma ilustração esquemática do radiotraçador alvo-específico, que se trata de complexos de um radiometal com um conjugado da biomolécula com o quelante. O radiotraçador alvo específico contendo metal pode ser dividido em quatro partes: biomolécula, espaçador, agente quelante bifuncional e radionuclídeo. A biomolécula serve como um carreador para transporte alvo-específico ao tecido desejado com muitos receptores alvo. $O$ ligante radiomarcado liga-se a esses receptores com alta afinidade e especificidade, 
resultando em captação seletiva do radiotraçador. A escolha do radionuclídeo depende da utilidade clínica do radiotraçador (ZHOU et al., 2011).

A escolha do quelante é crucial para o comportamento biológico do radiofármaco, no entanto, grande importância também deve ser dada à biomolécula carreadora ligada a ele. Uma variedade de agentes tem sido usada como quelante bifuncional na marcação de proteínas, peptídeos e outras moléculas biologicamente ativas pelo ${ }^{99 m}$ Tc (GARCIA-GARAYOA et al., 2006, MAINA et al., 2007, OLIVEIRA et al., 2012).

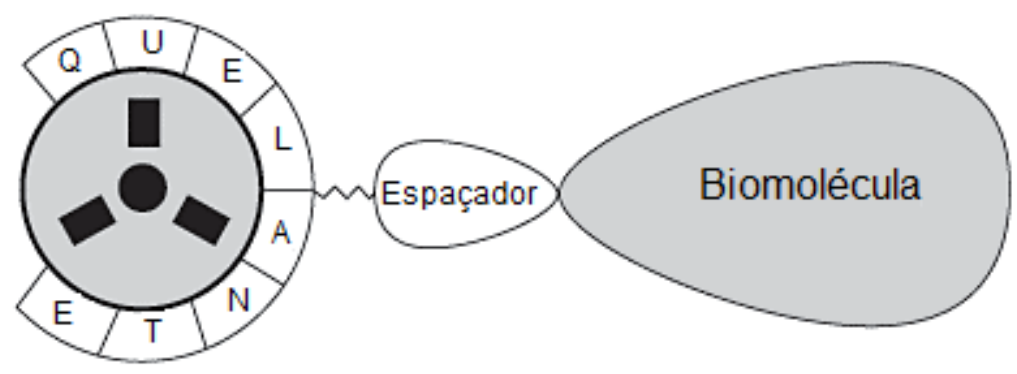

FIGURA 5 - Ilustração esquemática do radiotraçador alvo-específico (Liu et al., 2003).

\subsubsection{6-hidrazinonicotinamida (HYNIC) como agente quelante bifuncional}

HYNIC (FIG. 6) é um agente quelante bifuncional que tem sido amplamente estudado e empregado na marcação com ${ }^{99 m} \mathrm{Tc}$ devido a fácil conjugação à biomoléculas ((ERFANI et al., 2014; GUO et al., 2014). Historicamente, desde que Abrams et al. (1990) relataram primeiramente o uso de núcleos de $\left[{ }^{99 m}\right.$ Tc]HYNIC para marcação de imunoglubulinas ( $\left.\operatorname{lgG}\right)$, as investigações utilizando este núcleo foram realizadas, primordialmente, para radiomarcação de proteínas(HNATOWICH et al., 1993), pequenas biomoléculas, incluindo peptídeos quimiotáticos(VAN DER LAKEN et al., 1997), análogos da somatostatina(KOPECKY et al., 2004), oligonucleotídeos antisenso (HNATOWICH et al., 1995) e outros (ERFANI et al., 2014; GUO et al., 2014). 


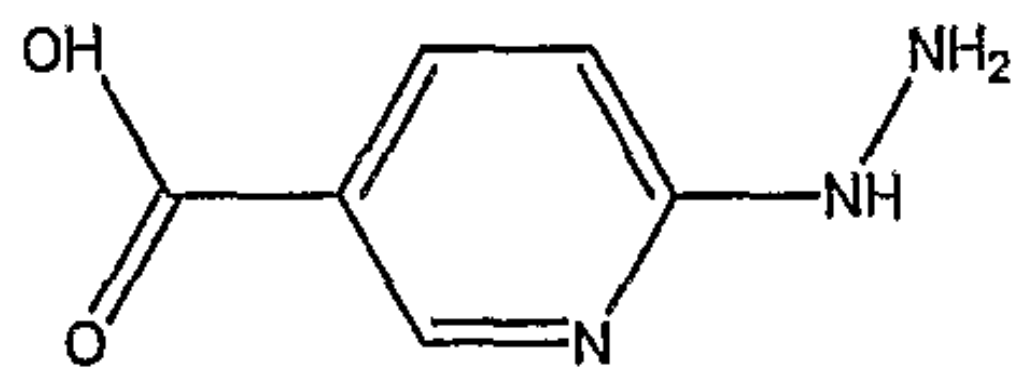

FIGURA 6 - Molécula de HYNIC.

Os complexos do HYNIC são quimicamente robustos, devido à dupla ligação estabelecida entre o isótopo e o nitrogênio (agrupamento hidrazina) disponível no HYNIC. Tal união ocorre provavelmente por uma reação de condensação entre o $[\mathrm{TcO}]^{3+}$ e o HYNIC. $\mathrm{O}^{99 \mathrm{~m}} \mathrm{Tc}$ pode-se também coordenar ao nitrogênio do anel piridinico deste agente quelante funcional (MESZAROS et al., 2010).

Para completar os sítios de coordenação do tecnécio (geometria piramidal quadrada ou octaédrica do complexo) é necessário o uso de coligantes (LIU et al., 2003). Dentre esses coligantes, destaca-se o EDDA (ácido etilenodiamino diacético) e a tricina devido à eficiência de marcação (FAINTUCH et al., 2005).

A utilização do HYNIC apresenta vantagens como, por exemplo, os altos rendimentos de marcação obtidos, além da escolha de coligantes, que permite a fácil modificação da hidrofilicidade e farmacocinética dos complexos radiomarcados com ${ }^{99 \mathrm{~m}}$ Tc (DECRISTOFORO et al., 2007; JANSSEN et al., 2002; SU et al., 2003). 
2 JUSTIFICATIVA 


\section{JUSTIFICATIVA}

O presente trabalho pretendeu, de forma inédita, desenvolver um

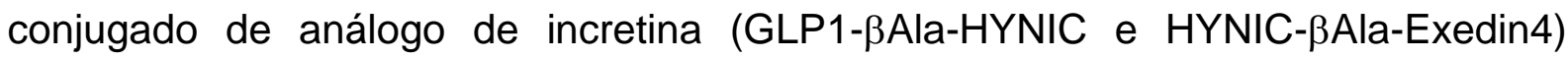
marcado com tecnécio-99m a fim de propor um método alternativo não invasivo de imagem para monitoração da massa de células beta pancreáticas. Além de não existir ainda disponível um radiotraçador específico para células beta, que as distinga de forma prática e clinicamente aplicável dos outros componentes das ilhotas de Langerhans.

Este é o primeiro estudo que, a nosso conhecimento, descreve o perfil do radiotraçador de incretina na monitoração da massa de células beta pancreáticas, em obesidade induzida e obesidade revertida pela dieta.

Recomenda-se a realização de estudos de seguimento longitudinal, assim como de cirurgia bariátrica e metabólica, com detalhamento celular e mapeamento molecular dos marcadores. 


\section{OBJETIVOS}

\subsection{Objetivo geral}

O objetivo geral do presente trabalho enfocou o desenvolvimento de um

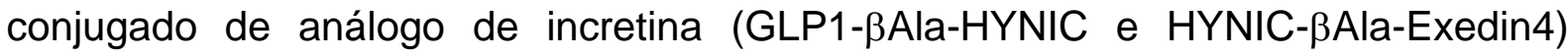
marcado com tecnécio-99m, a fim de propor um método não invasivo de imagem para monitoração da massa de células beta pancreáticas de enfermos clínicos acometidos por obesidade e diabetes.

\subsection{Objetivos específicos}

- Realizar a marcação de conjugados de diferentes análogos do "glucagon-like-peptide" GLP-1 com o radioisótopo tecnécio-99m e determinar sua caracterização radioquímica;

- Induzir os estados clínicos de diabetes e obesidade em camundongos Swiss;

- Verificar a eficácia da ração hiperlipídica preparada para a indução de obesidade em camundongos Swiss;

- Avaliar alterações estruturais do pâncreas, fígado e tecido adiposo de camundongos Swiss controle, obesos, diabéticos e pós-obesos por meio da técnica histológica em HE.

- Realizar estudo de biodistribuição e avaliação farmacocinética nos quatro modelos animais (controle, obesos, diabéticos e pós-obesos);

- Quantificar a captação radioativa ex-vivo dos órgãos de interesse por meio de imagens cintilográficas;

- Submeter os resultados obtidos a testes estatísticos. 


\section{MATERIAIS E MÉTODOS}

\subsection{Materiais}

\subsubsection{Infraestrutura}

Os ensaios foram realizados nos laboratórios de Pesquisa e Desenvolvimento do Centro de Radiofarmácia $(\mathrm{CR})$ e no Biotério, sendo todas as dependências situadas na área do IPEN-CNEN/SP. Esses laboratórios forneceram toda a infraestrutura necessária para a manipulação de materiais radioativos e animais, respectivamente.

\subsubsection{Reagentes e solventes}

Os principais reagentes e solventes utilizados neste trabalho foram:

- Cloreto estanoso dihidratado (Merck, Alemanha);

- Tricina (Sigma Aldrich, EUA);

- Solução fisiológica estéril (cloreto de sódio) 0,9\% (Equiplex, Brasil);

- Água purificada - Purificador Milli-RX 45 (Millipore, EUA);

- Acetonitrila, ácido clorídrico, ácido trifluoracético, éter dietílico, fosfato de sódio moobásico, fosfato disódico anidro, metiletilcetona, octanol, ácido tricloroacético (Merck, Alemanha);

- Gás nitrogênio, grau de pureza 99,99\% (White Martins, Brasil); 
- Radioisótopo tecnécio-99m, obtido do gerador molibdênio-99/tecnécio99m produzido no Centro de Radiofarmácia (IPEN-CNEN/SP);

- Heparina (Liquemine®), solução 5000 U.I./mL (Roche, Brasil);

- Aloxana monohidratada (Sigma Aldrich, EUA);

- Uretana (Sigma Aldrich, EUA);

- Ração normocalórica Nuvilab CR-1 Autoclavável 20 Kg (Nuvital, Brasil) à base de carbonato de cálcio, milho integral moído, farelo de arroz, farelo de trigo, fosfato de bicálcico, melaço, cloreto de sódio (sal comum), óleo de soja degomado e um premix mineral vitamínico;

- Ração hiperlipídica constituída por ração comercial para camundongos NUVILAB® CR-1 Autoclavável com adição de amendoim com casca Yoki, chocolate ao leite Garoto, bolacha maisena Arcor Triunfo e banha Frimesa, na proporção de 3:2:2:1:2, respectivamente.

- Conjugados Peptídicos - piChem, Áustria:

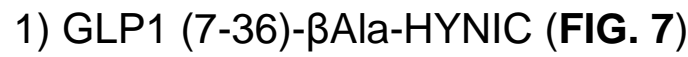

HAEGTFTSDVSSYLEGQAAKEFIAWLVKGR-K (HYNIC- $\beta$-Ala) NH2

2) HYNIC-BAla-Exedin4 (FIG. 8)

HYNIC( $\beta$-Ala) HGGGTFTSDLSKQMEEEAVRLFIEWLKNGGPSSGAPPPS-NH2

(B)

(A)

HAEGTFTSDVSSYLEGQAAKEFIAWLVKGR-K<smiles>CNC(=O)CCNC(=O)c1ccc(NN)nc1</smiles>

FIGURA 7 - Estrutura molecular do conjugado peptídico GLP1-HYNIC; (A) GLP1; (B) $\beta$-Ala; (C) HYNIC. Peso Molecular: 3632. 
(A)

(B)<smiles>NNc1ccc(C(=O)NCCC(=O)I)cn1</smiles>

(C) HGEGTFTSDLSKQMEEEAVRLFIEWLKNGGPSSGAPPPS-NH2

FIGURA 8 - Estrutura molecular do conjugado peptídico HYNIC-Exedin4; (A) HYNIC; (B) $\beta$-Ala; (C) Exedin4. Peso Molecular: 4392,8.

\subsubsection{Equipamentos e demais materiais}

Os principais equipamentos e materiais utilizados neste trabalho foram:

- Agitador/aquecedor Thermomixer Comfort 1,5 mL (Eppendorf, EUA);

- Calibrador de atividade $\mathrm{CRM}^{\mathrm{TM}}$ - 35R (Capintec, EUA);

- Contador automático tipo poço com cristal Nal (TI) - D5002 cobra II (Packard-Camberra, EUA);

- Cromatógrafo líquido de alta eficiência (CLAE) - 1260 Infinity HPLC system, Agilent Technologies Inc., Santa Clara, CA, USA com Agilent interface 35900E e detector de radiação Raytest Gabi;

- Balança analítica, modelo M-220 (Denver Instruments, EUA);

- Bomba de vácuo, modelo 825T (Fisaton, Brasil);

- Capela com sistema de exaustão (BRASLAB Equipamentos para Laboratório Ltda., Brasil);

- Freezer vertical com temperatura de $-70^{\circ} \mathrm{C}$ (Eletrolab, Brasil);

- Refrigerador Biflex 450L Frostfree, Biplex 450 (Cônsul, Brasil);

- Purificador de água Ellix acoplado a sistema de purificação MilliQ (Millipore, EUA); 
- Gama-câmara equipada com detector gama (Mediso, Hungria), colimador (Mediso, Hungria), software Console TH22 v.7.02 (Mediso, Hungria) e software InterviewXP ${ }^{\circledR}$ v1.05.014 (Mediso, Hungria);

- Estufa, modelo Orion 515 (Farrem, Brasil);

- Medidor de pH, modelo DM-31 (Digimed, Brasil);

- Agitador de tubos, modelo AP56 (Phoenix, Brasil);

- Fitas cromatográficas ITLC-SG (Instant Thin Layer Chromatography Silica Gel), 5 × $20 \mathrm{~cm}$ (Pall Corporation, EUA);

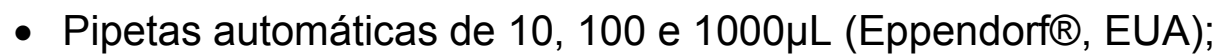

- Tubos reacionais de 1,5 mL, transparentes, mono-poliméricos- Axygen Scientific ${ }^{\circledR}$ MCT-150-C (Axygen, EUA);

- Medidor de glicemia, marca Accu Chek Active;

- Tiras para teste de glicemia, marca Accu Chek Active;

- Seringas de insulina de 1,0 mL (B\&D, EUA);

- Membranas filtrantes 0,22 $\mu \mathrm{m}$ (Millipore $\AA$, EUA);

- Fitas de pH, Neutralit pH 5-10 (Merck, Alemanha);

- Vidrarias em geral e instrumentos cirúrgicos.

\subsubsection{Animais}

Os camundongos fêmeas Swiss, da espécie Mus musculus, utilizados neste trabalho foram fornecidos pelo biotério do IPEN-CNEN/SP com peso inicial de 18 a 20 gramas. Todos os experimentos foram previamente aprovados pelo Comitê de Ética em Pesquisa do IPEN (Projeto n 147/14/CEUA-IPEN/SP, Anexo 1). A água e a alimentação estiveram disponíveis durante todo o processo de experimentação, 
exceto antes da coleta de sangue para dosagem de glicemia, em que os animais permaneceram 8 horas apenas com água.

\subsection{Métodos}

\subsubsection{Análise cromatográfica dos conjugados peptídicos}

Os conjugados peptídicos GLP-1-ßAla-HYNIC (PM = 3632) e HYNICBAla-Exedin4 ( $P M=4392,8)$ foram adquiridos comercialmente pela empresa piChem. A avaliação dos mesmos foi efetuada por Cromatrografia Líquida de Alta Eficiência (CLAE) usando uma coluna C18 de fase reversa com fluxo de $1 \mathrm{~mL} / \mathrm{min}$ e UV de $280 \mathrm{~nm}$. O sistema de solventes no CLAE consistiu em água contendo ácido trifluoracético 0,1\% - TFA (solvente A) e acetonitrila contendo $0,1 \%$ de ácido trifluoracético - TFA (solvente B). O gradiente cromatográfico começou com uma composição de $95 \%$ A e $5 \%$ B e de 1 a 25 min a composição foi mudando linearmente até $30 \% \mathrm{~A}$ e $70 \% \mathrm{~B}$, para finalmente dos 25 até os 30 min atingir uma composição de 5\% A e 95\% B (FAINTUCH et al., 2011).

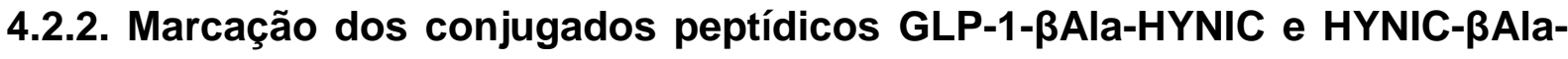 Exedin4}

Para a radiomarcação, o radioisótopo tecnécio-99m foi eluído de um gerador molibdênio-99/tecnécio-99m $\left({ }^{99} \mathrm{Mo} /{ }^{99 \mathrm{~m}} \mathrm{Tc}\right)$, em solução de cloreto de sódio $0,9 \%$ na forma de pertecnetato de sódio $\left(\mathrm{Na}^{99 \mathrm{~m}} \mathrm{TcO}_{4}\right)$.

Os sais dos conjugados peptídicos foram diluídos em água estéril na

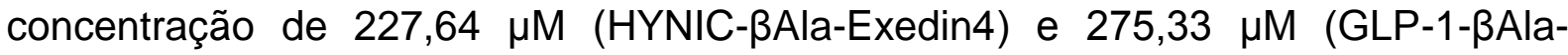
HYNIC). 
As soluções de $\mathrm{HCl} 0,1 \mathrm{~N}$ e tampão fosfato $0,1 \mathrm{M}$ foram preparadas previamente à marcação e nitrogenadas por cerca de 30 minutos. Todos os reagentes foram usados em condições estéreis.

O procedimento de radiomarcação dos conjugados foi realizado seguindose o protocolo definido pelo grupo de pesquisa sem o uso de EDDA (FAINTUCH et al., 2011), no qual se utilizou agente coligante e agente redutor.

Em um frasco de reação contendo $35 \mathrm{mg}$ de tricina dissolvido em 0,5 mL de solução tampão fosfato $0,1 \mathrm{M}$, adicionou-se $10 \mu \mathrm{L}$ de solução de conjugado peptídico, $15 \mu \mathrm{L}$ de solução de cloreto estanoso $\left(\mathrm{SnCl}_{2} .2 \mathrm{H}_{2} \mathrm{O}\right) 9 \mathrm{mM}$ em HCl $0,1 \mathrm{~N} \mathrm{e}$ $0,5 \mathrm{~mL}$ de pertecnetato de sódio $\left(\mathrm{Na}^{99 \mathrm{~m}} \mathrm{TcO}_{4}{ }^{-}\right)$com atividade de $740 \mathrm{MBq}(20 \mathrm{mCi})$ aproximadamente.

A mistura final $\left(\mathrm{pH} \mathrm{7)}\right.$, foi agitada e a reação realizada a $100^{\circ} \mathrm{C}$ por 20 minutos. Após o resfriamento, o volume foi completado para $1,5 \mathrm{~mL}$ com solução de cloreto de sódio ( $\mathrm{NaCl}$ ) 0,9\%, previamente nitrogenada.

\subsubsection{Avaliação radioquímica dos conjugados radiomarcados}

A avaliação radioquímica foi realizada por Cromatografia de Camada Delgada ascendente em fitas de sílica gel (ITLC-SG) utilizando-se os solventes metiletilcetona e acetonitrila 50\%. O cálculo radioquímico foi determinado em porcentagem da atividade de cada espécie radioquímica em relação à atividade total da fita, sempre de acordo com o fator de retenção (Rf) correspondente.

Outro método utilizado para a quantificação da eficiência radioquímica da marcação foi a Cromatografia Líquida de Alta Eficiência (CLAE). As condições experimentais utilizadas foram idênticas às descritas no item 4.2.1. 


\subsubsection{Determinação da lipofilicidade dos produtos radiomarcados}

A determinação da lipofilicidade dos produtos radiomarcados foi realizada por meio do teste de coeficiente de partição $(\mathrm{P})$, utilizando-se n-octanol e água como solventes (OKARVI, 2004).

Inicialmente, uma alíquota de $100 \mu \mathrm{L}$ do complexo radiomarcado foi adicionada a uma mistura de $6 \mathrm{~mL}$ de $\mathrm{n}$-octanol e água (1:1). A mistura foi homogeneizada em vórtex à $5000 x g$ durante 3 minutos à temperatura ambiente com a finalidade de se separar as duas fases (aquosa e orgânica). Após a centrifugação e repouso, foram coletadas amostras de $100 \mu \mathrm{L}$ de cada fase em triplicata e colocadas em tubos para a mensuração da atividade em contador gama tipo poço.

O coeficiente de partição $(P)$ foi calculado de acordo com a equação abaixo e expresso em $\log P$.

$$
\log P=\frac{\log \mathrm{cpm} \text { (octanol) }}{\log \mathrm{cpm} \text { (água) }}
$$

Onde: $\mathrm{cpm}=$ contagem por minuto .

\subsubsection{Delineamento dos estudos biológicos}

O planejamento experimental dos estudos biológicos consistiu das seguintes etapas:

1) Animais controle;

2) Animais diabéticos;

3) Ganho de peso nos animais sob dietas normocalórica e hiperlipídica;

4) Animais obesos;

5) Animais pós-obesos; 
6) Estudo de biodistribuição em camundongos controle, obesos, diabéticos e pós-obesos;

7) Determinação da ligação às proteínas plasmáticas;

8) Análise histológica de órgãos e tecido;

9) Quantificação ex-vivo por meio de imagens cintilográficas.

\subsubsection{Animais controle}

Este grupo de animais foi mantido com ração normocalórica ad libitum durante 60 dias, sem intervenção.

\subsubsection{Animais diabéticos}

Primeiramente, os camundongos foram alimentados da mesma forma que

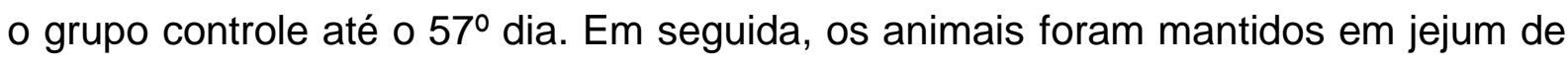
12 horas, visto que em jejum são mais sensíveis à aloxana (LEME et al., 2010). Os camundongos foram pesados em balança analítica antes da administração da droga, e na sequência, foram feitas a medição da glicemia (em $\mathrm{mg} / \mathrm{dl}$ ) utilizando um medidor de glicose da marca Accu Chek Active.

Logo após, injetou-se 50 $\mu \mathrm{L}$ de aloxana monoidratada (Sigma - Aldrich) dissolvida em tampão citrato $0,01 \mathrm{M} \mathrm{pH} \mathrm{4,5}$ por via intraperitoneal, na dose única de $150 \mathrm{mg} / \mathrm{kg}$ de peso corporal. Após aplicação da aloxana, administrou-se aos animais uma solução glicosada $5 \%$ via oral por 24 horas para evitar as complicações da hipoglicemia aloxânica (SHARMA et al., 2014).

Realizou-se a avaliação da glicemia (em jejum) no início e ao final do experimento, a fim de se comprovar o estado diabético dos animais. Foram considerados diabéticos apenas aqueles animais que apresentaram valores de glicemia superior a $300 \mathrm{mg} / \mathrm{dl}$ (TAMURA et al., 2015). Os animais tornaram-se diabéticos 3 dias após administração da aloxana. Foram considerados animais 
diabéticos aqueles que adquiriram glicemia final de jejum superior a $180 \mathrm{mg} / \mathrm{dl}$ (ETUK, 2010).

\subsubsection{Comparação do ganho de peso nos animais sob dietas normocalórica e hiperlipídica}

Para verificar a eficácia da ração hiperlipídica preparada para indução de obesidade em animais, os camundongos Swiss $(n=10)$ foram divididos em dois grupos e mantidos sob dietas distintas por um período de 30 dias: um grupo com dieta normocalórica com valor energético de $3860 \mathrm{kcal} / \mathrm{Kg}$ e o outro grupo com uma dieta hiperlipídica baseada na de Estadella et al. (2011), com valor energético de $5673,33 \mathrm{kcal} / \mathrm{Kg}$. Foi fornecida a mesma quantidade de ração, 50 gramas, para ambos os grupos.

Para o preparo da ração hiperlipídica, os ingredientes foram triturados e homogeneizados. Em seguida foi armazenada em refrigerador a temperatura de 4으 por 24 horas. Posteriormente, prepararam-se pellets e os mesmos foram assados em forno a $230^{\circ} \mathrm{C}$ por 16 minutos. Os pellets preparados foram mantidos em refrigerador a temperatura de $8^{\circ} \mathrm{C}$ para conservação dos mesmos. A TAB. 1 mostra a composição nutricional na ração experimental hiperlipídica dos animais.

TABELA 1 - Nutrientes presentes na ração experimental.

\begin{tabular}{|c|c|c|c|c|}
\hline $\begin{array}{c}\text { Composição } \\
\text { (em mg) }\end{array}$ & $\begin{array}{l}\text { Amendoim } \\
(1 \mathrm{Kg})\end{array}$ & $\begin{array}{l}\text { Chocolate ao } \\
\text { leite }(1 \mathrm{Kg})\end{array}$ & $\begin{array}{c}\text { Bolacha de } \\
\text { maisena }(0,5 \mathrm{Kg})\end{array}$ & $\begin{array}{l}\text { Banha } \\
(1 \mathrm{Kg})\end{array}$ \\
\hline Carboidratos & 200 & 600 & 383,33 & \\
\hline Proteínas & 273,33 & 60 & 40 & \\
\hline Gorduras totais & 473,33 & 304 & 50 & 1000 \\
\hline $\begin{array}{c}\text { Gorduras saturadas } \\
\text { Gorduras trans }\end{array}$ & 60 & 172 & 21,67 & 340 \\
\hline Fibra alimentar & 73,33 & 24 & 15 & \\
\hline Sódio & & 0,6 & 1,35 & \\
\hline
\end{tabular}


Realizou-se o controle do peso dos animais 2 vezes por semana ( $2^{\underline{a}}$ e $5^{\text {a }}$ feira), com pesagem em balança analítica digital com precisão de $1 \times 10^{-4} \mathrm{~g}$. Para a realização da pesagem dos animais, colocou-se um recipiente de polipropileno na balança, desconsiderando-se o peso do mesmo por meio da função "tarar", em seguida, colocou-se em seu interior um camundongo por vez, obtendo assim, o peso do animal.

Expressou-se o ganho do peso em termos absolutos (gramas adquiridas/período). Além disso, também foi calculada a porcentagem de peso total obtido após o consumo da dieta hiperlípidica em comparação ao peso inicial dos animais.

\subsubsection{Animais obesos}

Neste estudo, 10 animais foram mantidos no Biotério divididos individualmente em gaiolas. Para os animais foram fornecidos água ad libitum e ração hiperlipídica no período de 30 dias, após 30 dias com ração normocalórica (semelhante ao grupo controle). Foram realizadas pesagens dos animais, uma vez por semana, para acompanhamento da evolução do peso e verificação da glicemia (em jejum) no $1^{\circ}$ e $30^{\circ}$ dia pós ingesta desta dieta. Os animais que adquiriram aumento de $50 \%$ do peso corpóreo foram considerados obesos.

\subsubsection{Animais pós-obesos}

O estudo de desenvolvimento de obesidade nos animais $(n=10)$ foi realizado conforme descrito no item 4.2.5.4. Após o período de 30 dias, os camundongos que estavam sob dieta hiperlipídica, foram mantidos com ração normocalórica a fim de induzir a perda de peso nos animais como simulação do que ocorre com pacientes submetidos à cirurgia bariátrica. Também foi realizada a aferição da glicemia (em jejum) no início e ao fim deste experimento. 


\subsubsection{Estudo de biodistribuição em animais controle, obesos, diabéticos e pós-obesos}

O estudo de biodistribuição foi realizado em animais com a injeção de $50 \mu \mathrm{L}(\sim 24,67 \mathrm{MBq})$ do radiotraçador na veia caudal dos mesmos. Para o grupo de animais controle o estudo foi conduzido em diferentes tempos (10, 30, 60 e 120 minutos) após administração da droga. Já para os demais grupos (obeso, diabético e pós-obeso), o estudo foi conduzido apenas para o tempo de 60 minutos após a administração do radiotraçador. Este tempo foi definido com base nos melhores resultados obtidos para a farmacocinética das drogas no grupo controle.

Os animais foram anestesiados 10 min antes da eutanásia. Para cada tempo e radiotraçador (HYNIC- $\beta$-Ala-Exedin4 e GLP1- $\beta$-Ala-HYNIC) foram utilizados 5 animais.

Órgãos e tecidos (sangue, coração, pulmão, rins, baço, estômago, pâncreas, fígado, intestino grosso e delgado, músculo, osso e gordura) foram dissecados, pesados e acondicionados em tubos para que a sua atividade radioativa fosse medida em contador gama do tipo poço de $\mathrm{Nal}(\mathrm{TI})$. A cauda foi retirada para correção da atividade administrada. Vale mencionar que a radioatividade nos intestinos foi avaliada após a remoção do conteúdo luminal.

O padrão foi preparado com o mesmo volume de radiotraçador administrado nos camundongos, e colocado para a contagem da atividade no mesmo momento em que a atividade dos órgãos foi mensurada. As porcentagens de dose injetada por órgão (\%Dl/órgão) e por grama (\%Dl/g), de todos os órgãos e tecidos avaliados, foram calculadas considerando o padrão como $100 \%$ da dose administrada aos animais.

A atividade no sangue total foi calculada para uma volemia de $7 \%$ do peso corpóreo do animal multiplicado pela $\% \mathrm{DI} / \mathrm{mL}$. A porcentagem de dose injetada (\%DI) do músculo e do osso total foi calculada assumindo, respectivamente, um volume de $40 \%$ e $10 \%$ do peso corpóreo respectivamente. 


\subsubsection{Determinação da ligação às proteínas plasmáticas}

Os estudos in vitro de ligação às proteínas plasmáticas para os produtos radiomarcados foram realizados por meio do método de precipitação (VanlićRazumenic et al., 1984).

Alíquotas de sangue foram coletadas de camundongos fêmeas Swiss, previamente anestesiados, nos tempos de 10, 30, 60 e 120 minutos após administração da droga. Estas amostras foram transferidas para tubos de fundo cônico, previamente heparinizados, e o experimento realizado em triplicata. Em seguida, centrifugou-se as amostras de sangue por 15 minutos $(1,877 \times \mathrm{xg})$ a temperatura ambiente afim de coletar o plasma sanguíneo. À $200 \mu \mathrm{L}$ do plasma adicionou-se $1 \mathrm{~mL}$ de ácido tricloroacético (TCA 10\%). Os tubos foram centrifugados por 15 minutos $(2,815 \mathrm{xg})$ a temperatura de $4^{\circ} \mathrm{C}$. O sobrenadante foi descartado e o procedimento repetido por mais duas vezes. Após a última centrifugação, o precipitado foi reservado e a radioatividade mensurada no contador tipo poço $\mathrm{Nal}$ (TI) com o padrão (cpm total), que corresponde ao plasma intacto (200 $\mu \mathrm{L})$. A porcentagem de ligação às proteínas plasmáticas de cada conjugado radiomarcado foi calculada de acordo com a equação abaixo:

$$
\text { \% Ligação às proteínas plasmáticas }=\frac{\mathrm{cpm}(\text { precipitado) }}{\mathrm{cpm}(\text { total })} \times 100
$$

Onde: $\mathrm{cpm}($ total $)=\mathrm{cpm}($ plasma intacto $)$

\subsubsection{Análise histológica de órgãos e tecido}

A análise histológica de órgãos e tecido de camundongo foi realizada no Departamento de Estomatologia da Faculdade de Odontologia da Universidade de São Paulo (FOUSP) e o laudo das avaliações microscópicas no Centro Veterinário de Anatomia Patológica (CVAP). 
Os animais foram sacrificados e órgãos e tecido (pâncreas, fígado e tecido adiposo) foram coletados e imediatamente imersos em uma solução de formol tamponado a 10\% para serem fixados. Após 24 horas, esses órgãos/tecido foram transferidos para álcool $70 \%$. Esta solução foi renovada periodicamente, conforme a eliminação dos resíduos de fixador. Os órgãos/tecido permaneceram em álcool 70\% até a completa desidratação das peças, e posteriormente foram diafanizados em xilol em temperatura ambiente.

As peças foram colocadas em parafina, em seguida, foram realizados os cortes com $5 \mu \mathrm{m}$ de espessura e corados com hematoxilina-eosina (HE).

As observações dos cortes histológicos foram realizadas por microscopia de luz comum utilizando microscópio óptico da marca Olympus BX 51, com câmera de vídeo acoplada a um computador, contendo um programa para análise de imagens, especializado em estereologia, denominado C.A.S.T. System, Olympus, Denmark.

\subsubsection{Quantificação ex-vivo por meio de imagens cintilográficas}

A captação dos radiotraçadores nos órgãos fígado, pâncreas, coração e intestino (delgado e grosso) foram avaliados com imagem ex-vivo realizado em gama-câmara equipada com um colimador de baixa energia e alta resolução, sob ângulo de $90^{\circ}$ e uma matriz de $256 \times 256 \times 16$, durante 180 segundos. Os valores foram quantificados considerando-se a dose injetada como padrão.

\subsubsection{Forma de análise dos resultados}

Os resultados foram apresentados em forma de porcentagens, média e desvio padrão, especificando o tamanho amostral (n). Gráficos e traçados foram incluídos quando necessário. A análise estatística foi realizada usando a análise de variância (ANOVA) e teste de Tukey $(p<0,05)$, a partir do software Bioestat versão 5.0 (AYRES et al., 2007). 
5 RESULTADOS 


\section{RESULTADOS}

\subsection{Análise cromatográfica dos conjugados peptídicos}

A análise dos conjugados peptídicos GLP1- $\beta$-Ala-HYNIC e HYNIC- $\beta$-AlaExedin4 em ultra-violeta demonstrou pureza superior a 90\% (FIG. 9). Pode-se observar que os tempos de retenção $\left(t_{R}\right)$ para os mesmos foram próximos $(18,102$ min para o GLP1 e 17,379 min para o Exedin4).

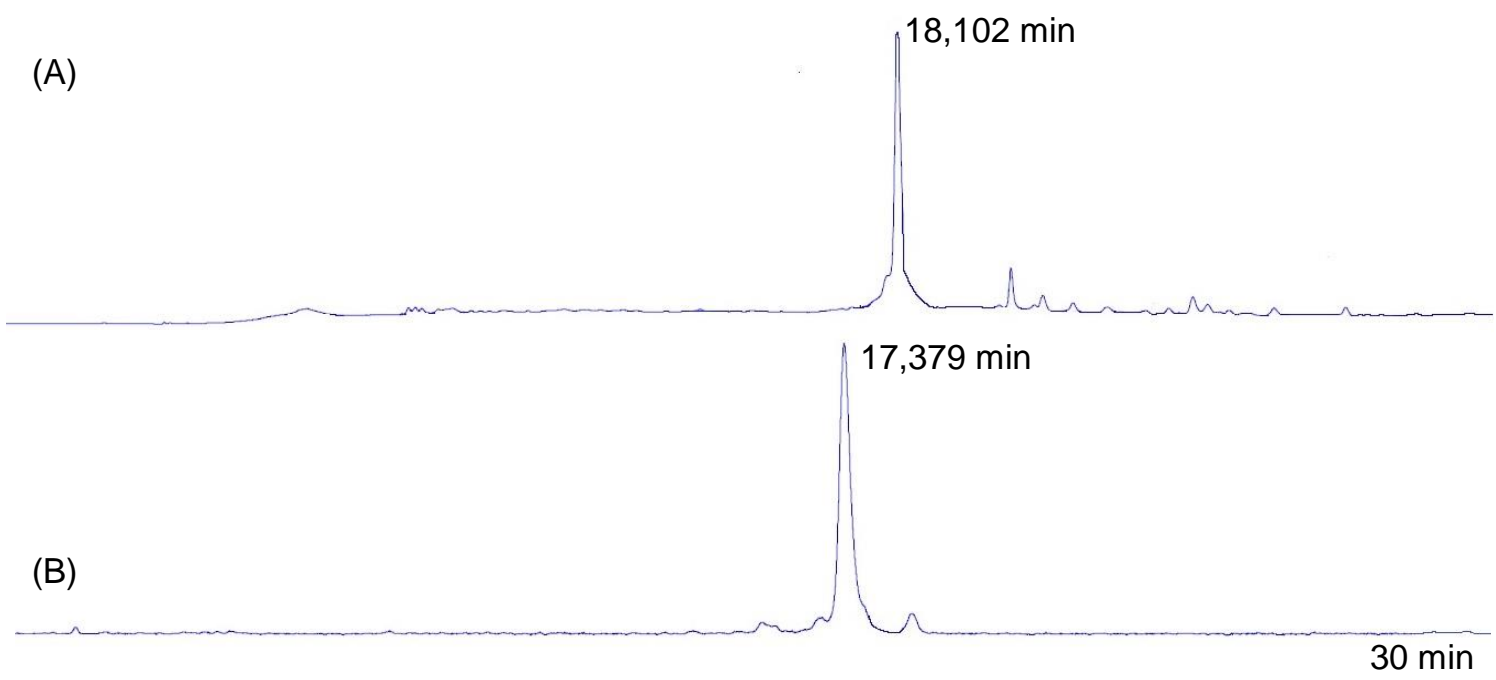

FIGURA 9 - Cromatograma dos conjugados peptídicos (A) GLP1- $\beta$-Ala-HYNIC e (B) HYNIC- $\beta$-Ala-Exedin4.

\subsection{Radiomarcação e avaliação radioquímica dos conjugados radiomarcados}

Os conjugados peptídicos foram radiomarcados e obtidos com elevada pureza $\left(97,10 \pm 0,73 \%\right.$ para o GLP1- $\beta$-Ala-HYNIC- ${ }^{99 m}$ Tc e $97,07 \pm 1,60 \%$ para o ${ }^{99 m}$ Tc-HYNIC- $\beta$-Ala-Exedin4) e atividade específica de 402,17 MBq/nmol e 486,8 $\mathrm{MBq} / \mathrm{nmol}$, respectivamente. 
$\mathrm{Na}$ avaliação realizada por cromatografia de camada delgada ascendente em fitas de sílica gel (ITLC-SG) observou-se que os conjugados radiomarcados e a impureza coloidal, ${ }^{99 m} \mathrm{TcO}_{2}$, ficam no início da fita $\left(\mathrm{R}_{\mathrm{t}}=0\right)$ na fase móvel metiletilcetona. Com o uso do solvente acetonitrila $50 \%$, o produto desloca-se $\left(R_{t}=1\right)$ juntamente com a impureza de ${ }^{99 \mathrm{~m}} \mathrm{Tc}$ livre na forma de pertecnetato de sódio $\left(\mathrm{Na}^{99 \mathrm{~m}} \mathrm{TcO}_{4}\right)$.

Os resultados obtidos por CLAE com tempo de retenção $\left(t_{R}\right)$ de 18,48 min para o GLP1- $\beta$-Ala-HYNIC- ${ }^{99 \mathrm{~m}}$ Tc e 18,463 min para o ${ }^{99 \mathrm{~m}} \mathrm{Tc}$-HYNIC- $\beta$-Ala-Exedin4, confirmaram os valores encontrados por meio da cromatografia de camada delgada, resultando em uma única espécie radioquímica principal para cada conjugado radiomarcado (FIG. 10). Aos $3,24 \mathrm{~min}$ pode-se observar um pequeno pico, correspondente à impureza ${ }^{99 \mathrm{~m}} \mathrm{TcO}_{4}^{-}(1,02 \%)$.

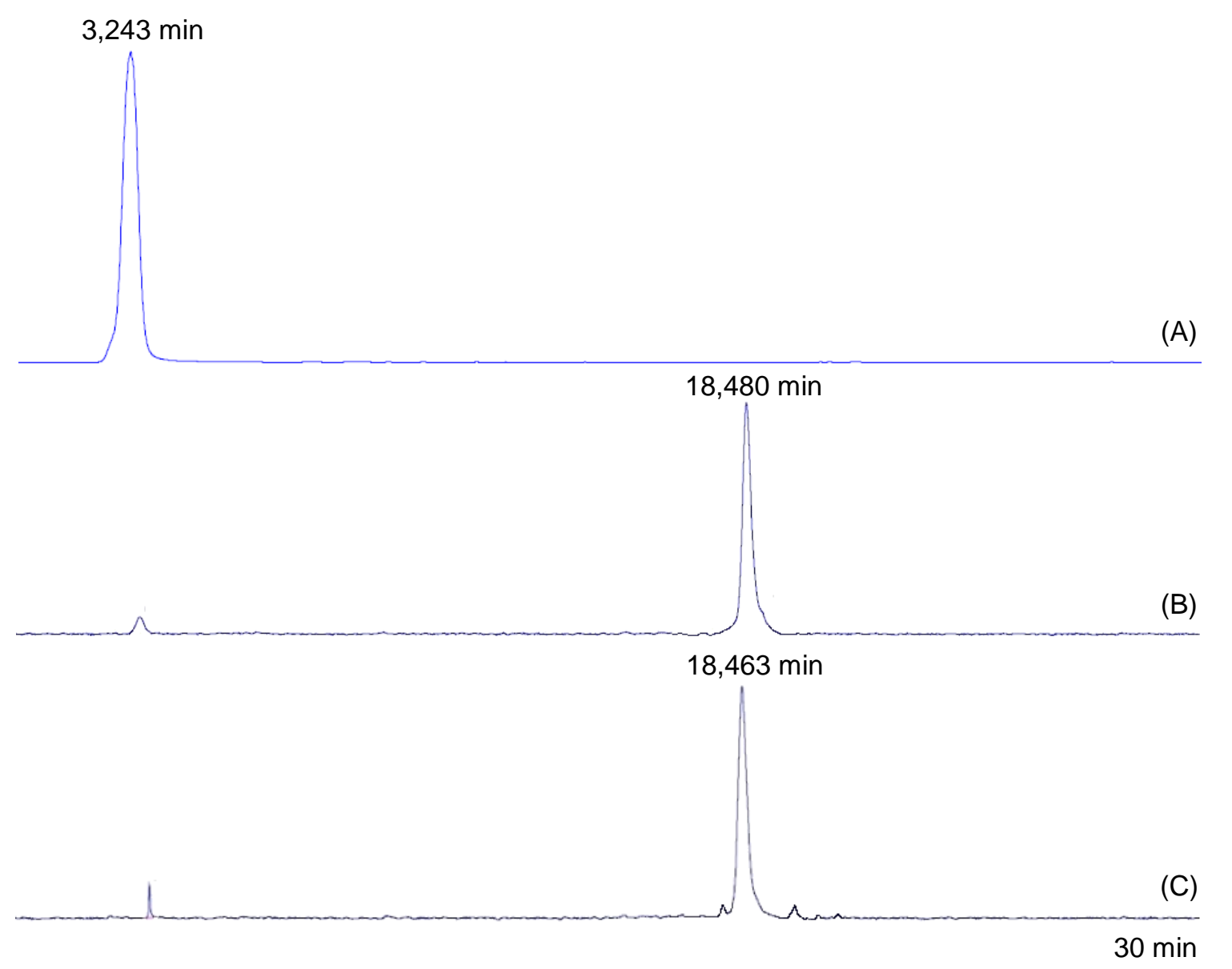

FIGURA 10 - Radiocromatograma do (A) ${ }^{99 \mathrm{~m}} \mathrm{TcO}_{4}$; (B) GLP1- $\beta$-Ala-HYNIC-- ${ }^{99 \mathrm{~m}} \mathrm{TC}$; (C) ${ }^{99 \mathrm{~m}}$ Tc-HYNIC- $\beta$-Ala-Exedin4. 


\subsection{Determinação da lipofilicidade dos produtos radiomarcados}

Os dois radiotraçadores analisados estão na faixa de hidrofilicidade. Os valores do coeficiente de partição dos radiotraçadores foram de $\log P=-0,89 \pm 0,02$ para o traçador GLP-1 e $\log P=-1,33 \pm 0,09$ para o traçador Exedin4, evidenciando uma maior hidrofilicidade para este último, com diferença significativa entre eles $(p<$ 0,05).

\subsection{Animais diabéticos}

A FIG. 11 evidencia os valores de peso e glicemia antes e após a administração da aloxana nos animais.

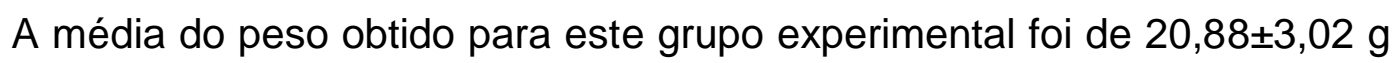
pré-injeção e 21,04£3,35 g pós-injeção de aloxana. Para o índice glicêmico foi obtida a média de 83,36 \pm 4,92 mg/dL pré-injeção e 537,30 \pm 25,31 mg/dL pós-injeção de aloxana.

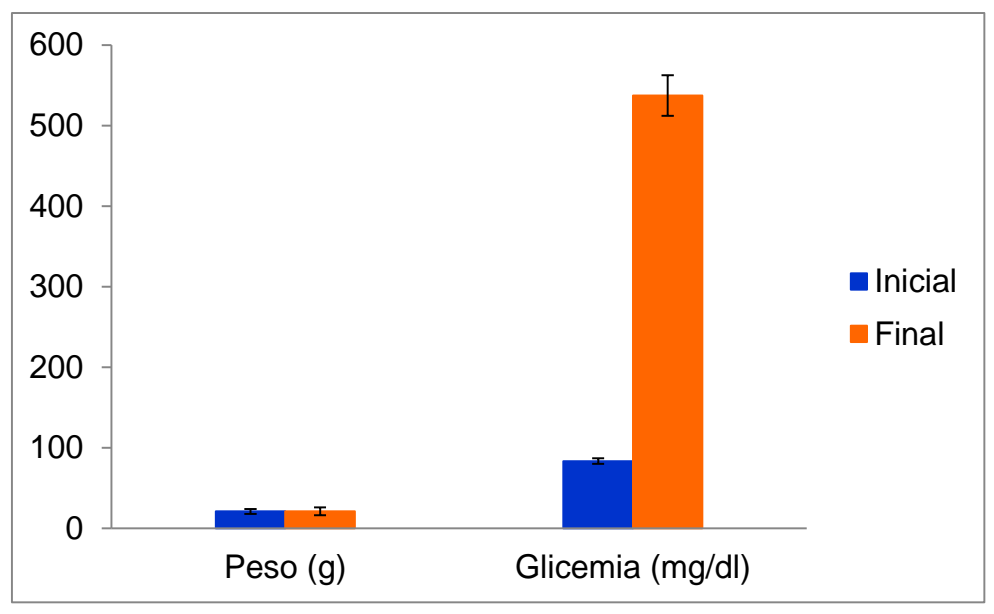

FIGURA 11 - Valores de glicemia e peso antes e após a administração da aloxana.

\subsection{Comparação do ganho de peso nos animais sob dietas normocalórica e hiperlipídica}

Na FIG. 12 pode-se observar a evolução do ganho de peso (em gramas) dos camundongos Swiss $(\mathrm{n}=10)$ que permaneceram sob dietas normocalórica (DN) 
e hiperlipídica $(\mathrm{DH})$ durante o período de 1 mês. As médias dos pesos corporais (inicial e final) dos animais com DN e DH variaram de $21,20 \pm 1,18$ a $28,90 \pm 4,12$ gramas e 19,68 $\pm 1,87$ a $46,14 \pm 6,06$ gramas, respectivamente.

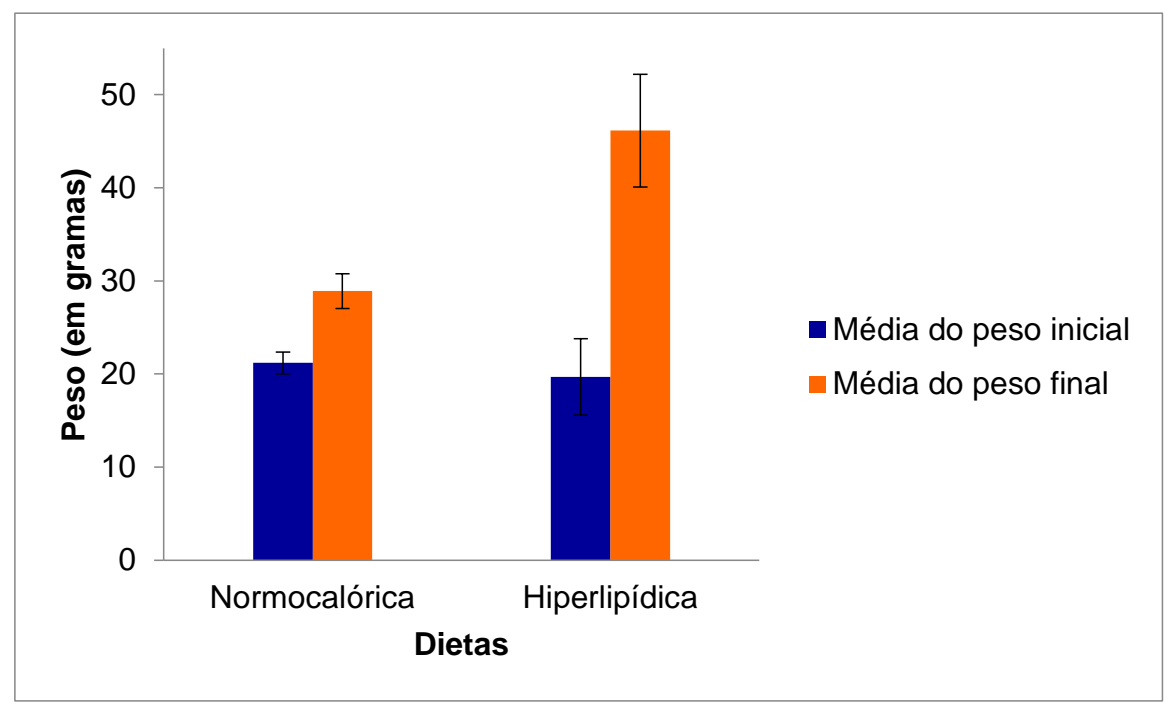

FIGURA 12 - Médias dos pesos corporais (inicial e final) dos animais com dietas normocalórica e hiperlipídica.

Com relação ao aumento de peso dos animais sob dietas normocalórica e hiperlipídica, nota-se que em termos de peso absoluto variou de 6,51 a 11,48 gramas e 20,66 a 34,48 gramas, respectivamente. Já em termos de porcentagem, os animais com dieta normocalórica e hiperlipídica obtiveram aumento de 16,56 a $52,47 \%$ e 110,19 a 168,34\% do peso corpóreo, respectivamente (FIG. 13 e 14)

Um aspecto importante desse modelo de obesidade induzida se refere ao valor energético das dietas. Neste estudo as DN e DH possuem 3,86 Kcal/g e 5,67 $\mathrm{Kcal} / \mathrm{g}$, respectivamente. Comparando estes valores com os encontrados na literatura (NASCIMENTO et al., 2008; ABREU, 2012; TEIXEIRA, 2012), evidencia-se uma mesma ordem de grandeza para a DN, e ligeiramente superior para a $\mathrm{DH}$. 


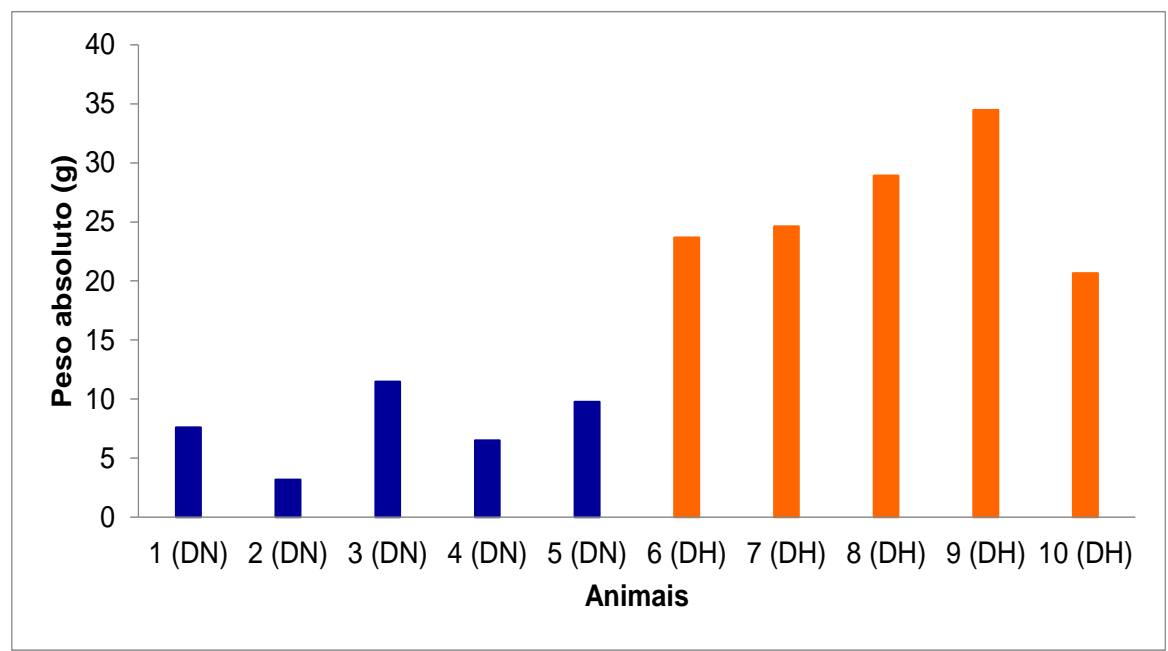

FIGURA 13 - Aumento de peso absoluto de animais com dieta normocalórica e hiperlipídica.

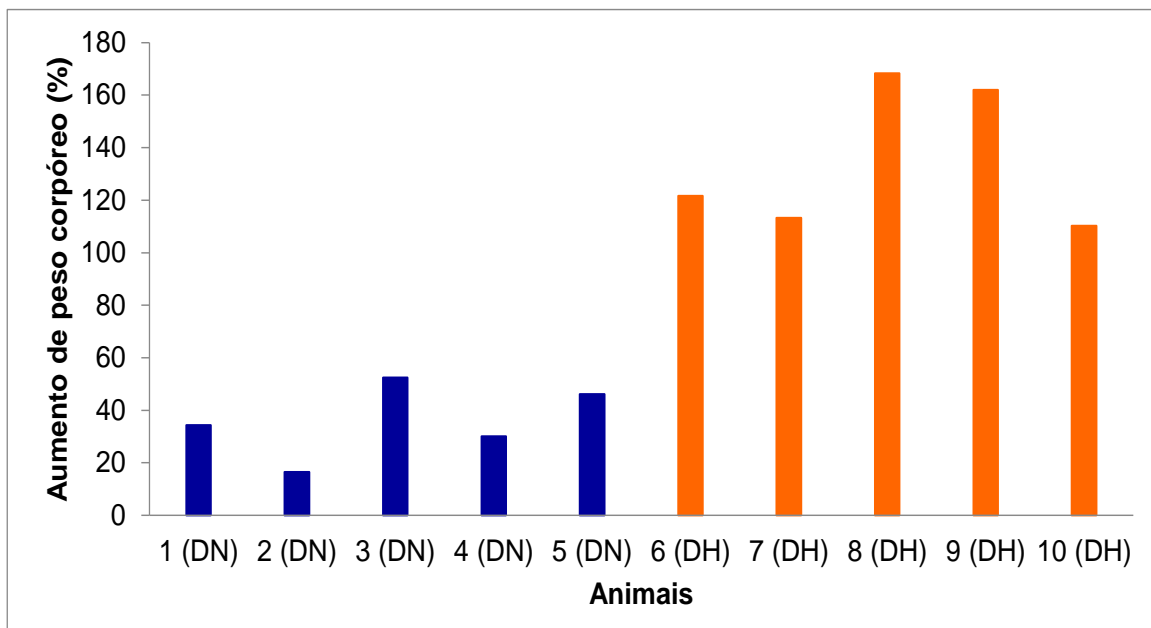

FIGURA 14 - Aumento da porcentagem de peso de animais com dieta normocalórica e hiperlipídica.

\subsection{Animais obesos}

Os valores dos pesos (em gramas) dos animais sob dieta experimental hiperlipídica, averiguados semanalmente, podem ser observados na TAB. 2.

Com relação ao aumento de peso dos animais sob dieta hiperlipídica, nota-se que em termos de peso absoluto variou de 18,97 a 30,16 gramas $(x=25,95$ 
$\pm 4,19 \mathrm{~g})$. Já em termos de porcentagem, os animais obtiveram aumento de 102,71 a $162,56 \%(x=137,97 \pm 20,26 \%)$ do peso corpóreo.

TABELA 2 - Evolução do ganho de peso de camundongos Swiss sob dieta hiperlipídica.

\begin{tabular}{|c|c|c|c|c|c|c|c|}
\hline \multirow{2}{*}{ Animais } & \multirow{2}{*}{$\begin{array}{c}\text { Peso } \\
\text { inicial }\end{array}$} & \multirow[b]{2}{*}{$1^{a}$} & \multicolumn{2}{|c|}{ Semana } & \multirow[b]{2}{*}{$4^{a}$} & \multirow{2}{*}{$\begin{array}{c}\text { Peso } \\
\text { absoluto (g) }\end{array}$} & \multirow{2}{*}{ Aumento (\%) } \\
\hline & & & $2^{a}$ & $3^{\mathbf{a}}$ & & & \\
\hline 1 & 18,88 & 26,46 & 34,80 & 38,80 & 41,56 & 22,68 & 120,13 \\
\hline 2 & 20,64 & 33,97 & 43,51 & 43,81 & 50,26 & 29,62 & 143,51 \\
\hline 3 & 18,22 & 30,58 & 36,65 & 38,97 & 42,70 & 24,48 & 134,36 \\
\hline 4 & 18,38 & 26,78 & 28,63 & 38,63 & 46,70 & 28,32 & 154,08 \\
\hline 5 & 18,25 & 27,78 & 34,02 & 38,06 & 43,89 & 25,64 & 140,49 \\
\hline 6 & 19,39 & 30,30 & 35,40 & 42,72 & 50,91 & 31,52 & 162,56 \\
\hline 7 & 18,44 & 29,39 & 34,08 & 34,76 & 39,22 & 20,78 & 112,69 \\
\hline 8 & 19,06 & 29,87 & 34,36 & 41,87 & 49,22 & 30,16 & 158,24 \\
\hline 9 & 18,47 & 31,34 & 35,55 & 32,25 & 37,44 & 18,97 & 102,71 \\
\hline 10 & 18,09 & 28,59 & 34,53 & 38,61 & 45,39 & 27,30 & 150,91 \\
\hline$M \pm D P$ & $18,78 \pm 0,77$ & $29,51 \pm 2,25$ & $35,15 \pm 3,63$ & $43,82 \pm 4,72$ & $44,73 \pm 4,61$ & $25,95 \pm 4,19$ & $137,97 \pm 20,26$ \\
\hline
\end{tabular}

Também foi realizada a medição da glicemia (em jejum) antes e após a ingestão da dieta hiperlipídica, conforme mostra a FIG. 15.

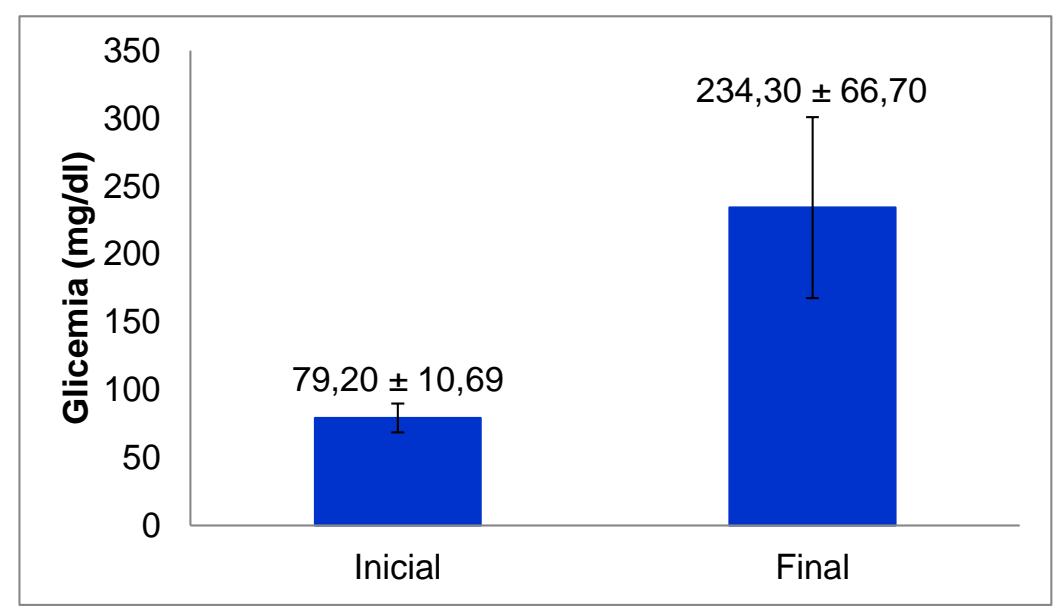

FIGURA 15 - Valores de glicemia inicial e final (em mg/dL) após ingestão de DH. 


\subsection{Animais pós-obesos}

Na FIG. 16 pode-se observar a evolução do ganho e da perda de peso (em gramas) dos camundongos Swiss $(\mathrm{n}=10)$ que permaneceram sob dietas hiper e hipolipídica.

As médias dos pesos corporais (inicial e final) dos animais com dietas hiper e normocalórica variaram de 17,96 \pm 0,65 a 44,73 \pm 4,61 gramas e 44,73 \pm 4,61 a 31,51 $\pm 4,33$ gramas, respectivamente. Nota-se que o aumento do peso pela dieta hiperlipídica foi considerável ( $x=149,05 \%$ ). Os animais mantidos com dieta hipolipídica obtiveram uma diminuição média de 29,76\% do peso corpóreo.

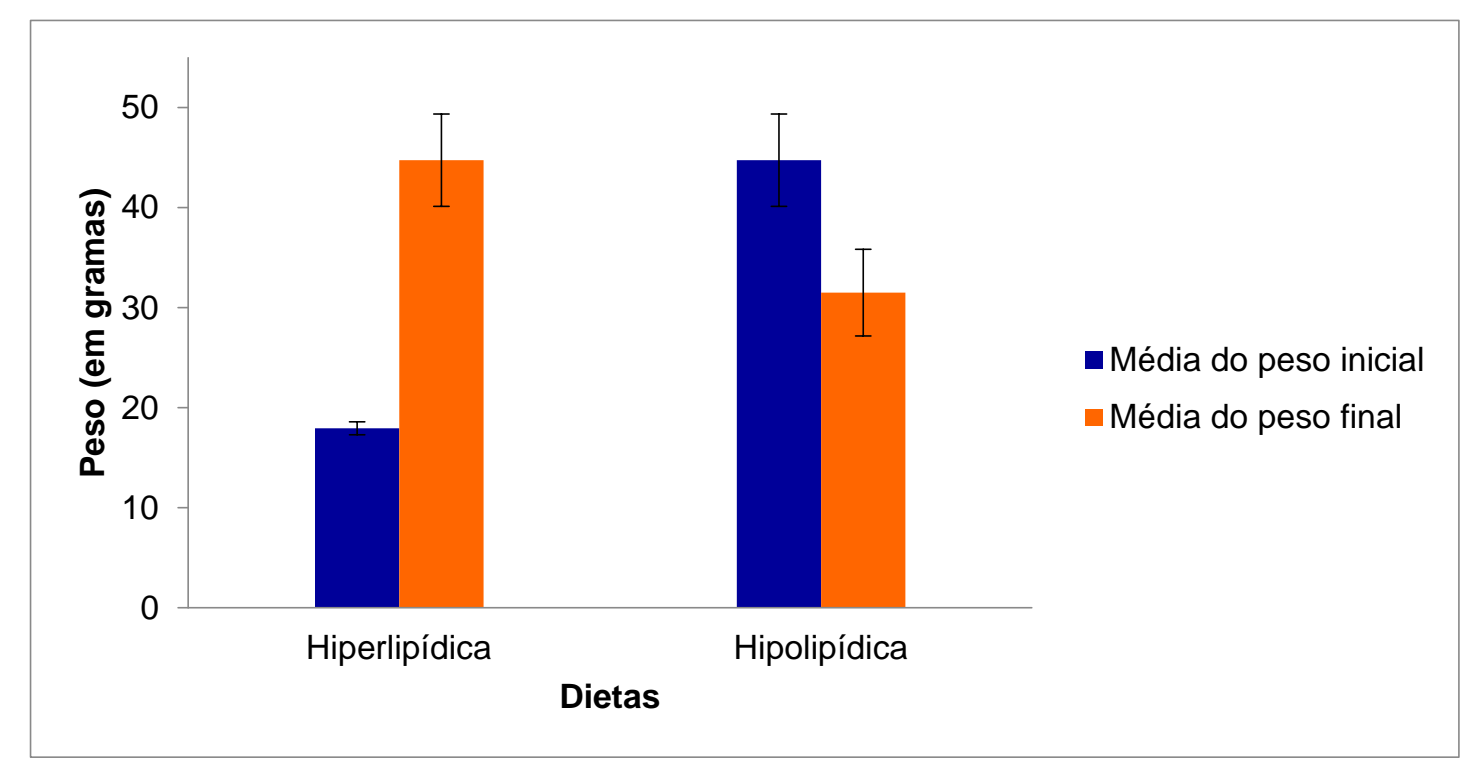

FIGURA 16 - Médias dos pesos corporais (inicial e final) dos animais com dietas hiper e hipolipídica.

Além disso, realizou-se a medição da glicemia (em jejum) antes e após a ingestão das dietas hiperlipídica (30 dias) e hipolipídica (60 dias), conforme mostra a FIG. 17. Ao final do estudo, verifica-se que a glicemia apresenta-se próxima da faixa de normalidade (atenuação do diabetes obesidade-dependente). 


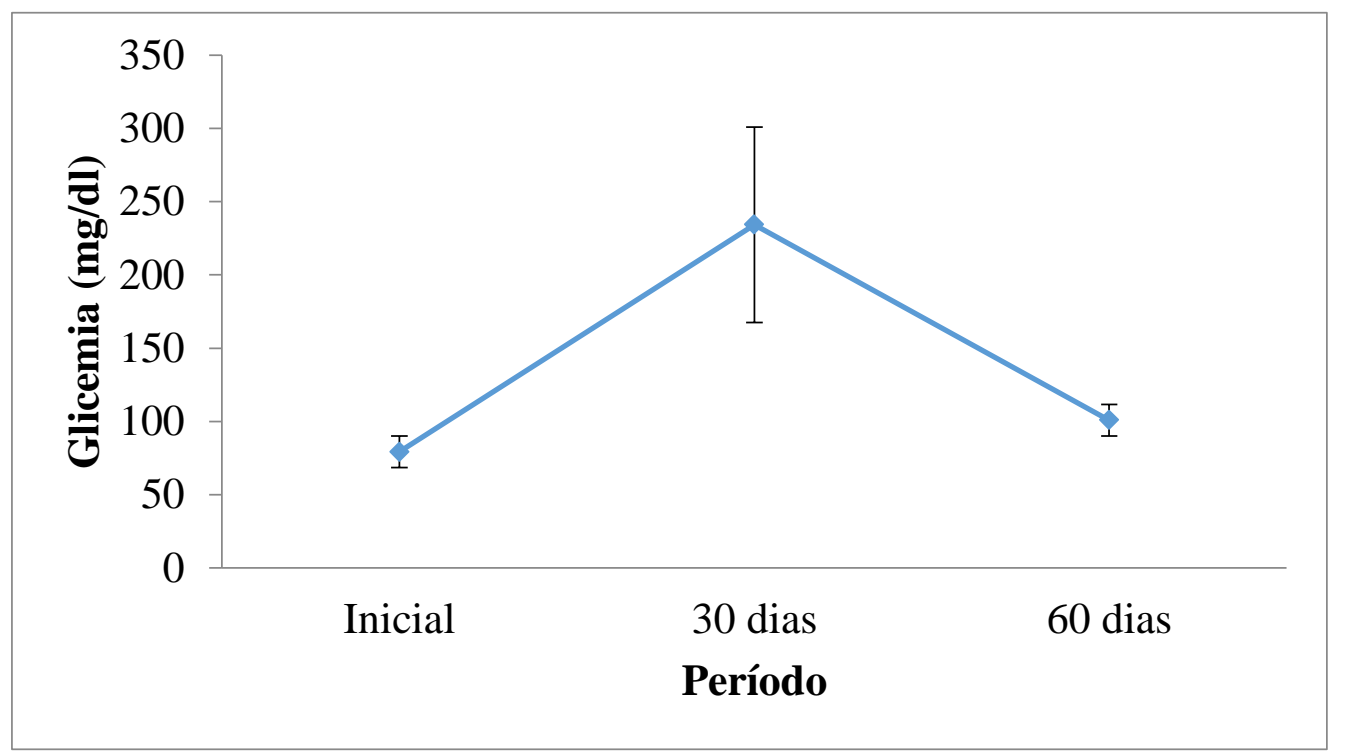

FIGURA 17 - Média da glicemia (em mg/dL) nos animais pós-obesos.

Esta situação mimetiza o padrão observado em cirurgia bariátrica no qual a reversão da obesidade e diabetes é acentuada, porém sem atingir $100 \%$ de valores normais.

\subsection{Biodistribuição em camundongos Swiss controle, obesos, diabéticos e pós-obesos}

A biodistribuição dos produtos radiomarcados em animais controle foram expressos em\% DI/g, como mostra a TAB. 3.

A depuração sanguínea dos radiotraçadores avaliada em animais controle pode ser observada na FIG. 18. Ambos radiomarcados apresentaram padrões similares. Verificou-se uma acentuada captação sanguínea no tempo precoce (10 min), com uma depuração elevada (> 80\%) após 1 hora, para ambos os peptídeos radiomarcados. Comparando-se os resultados obtidos é observada diferença significativa de $95 \%$ entre os produtos para os tempos de $10 \mathrm{~min}$ e $1 \mathrm{~h}$ de depuração. 


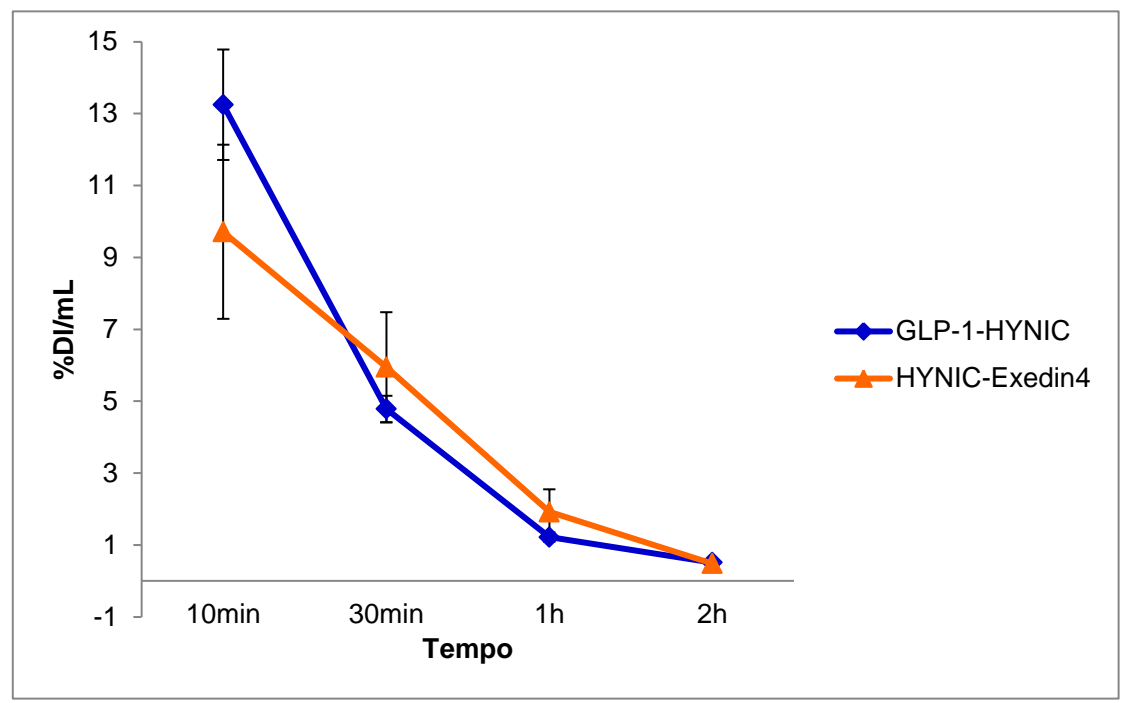

FIGURA 18 - Depuração sanguínea dos radiotraçadores GLP1- $\beta$-Ala-HYNIC- ${ }^{99 m}$ Tc $e^{99 m}$ Tc-HYNIC- $\beta$-Ala-Exedin4 em camundongos Swiss controle $(n=5) .\left(^{*}\right) p<0,05$.

A captação renal foi bastante acentuada, para os dois radiotraçadores, indicando a via urinária como principal meio de excreção. Esta alta captação é decorrente da hidrofilicidade dos compostos, devido à estrutura da molécula possuir o agente quelante bifuncional HYNIC e como espaçador o aminoácido beta alanina. Também foi observada captação hepática, porém bem inferior do que a renal. 
TABELA 3 - Biodistribuição dos radiotraçadores em camundongos Swiss controle (\%Dl/g \pm DP, $n=5)$.

\begin{tabular}{|c|c|c|c|c|c|c|c|c|}
\hline \multirow{3}{*}{ Órgão } & \multicolumn{8}{|c|}{ Time } \\
\hline & \multicolumn{2}{|c|}{$10 \mathrm{~min}$} & \multicolumn{2}{|c|}{$30 \mathrm{~min}$} & \multicolumn{2}{|c|}{$60 \mathrm{~min}$} & \multicolumn{2}{|c|}{ 120min } \\
\hline & GLP-1* & Exedin $^{\star \star}$ & GLP-1 & Exedin4 & GLP-1 & Exedin4 & GLP-1 & Exedin4 \\
\hline Sangue & $13,25 \pm 1,53$ & $9,71 \pm 2,42$ & $4,78 \pm 0,37$ & $5,95 \pm 1,53$ & $1,22 \pm 0,13$ & $1,02 \pm 0,41$ & $0,51 \pm 0,07$ & $0,49 \pm 0,10$ \\
\hline Coração & $3,95 \pm 0,67$ & $3,74 \pm 0,50$ & $1,57 \pm 0,34$ & $3,76 \pm 0,30$ & $0,81 \pm 0,11$ & $0,96 \pm 0,17$ & $0,42 \pm 0,06$ & $0,37 \pm 0,21$ \\
\hline Pulmão & $10,49 \pm 0,97$ & $19,84 \pm 0,42$ & $3,36 \pm 0,61$ & $9,78 \pm 0,98$ & $2,09 \pm 0,25$ & $5,50 \pm 0,71$ & $1,38 \pm 0,33$ & $1,54 \pm 0,10$ \\
\hline Rins & $76,90 \pm 3,43$ & $64,06 \pm 4,30$ & $53,74 \pm 2,86$ & $50,78 \pm 3,91$ & $61,69 \pm 2,20$ & $47,72 \pm 4,83$ & $51,27 \pm 1,74$ & $35,63 \pm 0,96$ \\
\hline Baço & $5,23 \pm 0,09$ & $6,62 \pm 0,15$ & $2,53 \pm 0,42$ & $4,35 \pm 0,40$ & $1,35 \pm 0,18$ & $1,40 \pm 0,50$ & $1,18 \pm 0,06$ & $1,43 \pm 0,43$ \\
\hline Estômago & $2,51 \pm 0,10$ & $2,97 \pm 0,21$ & $1,52 \pm 0,16$ & $2,89 \pm 0,53$ & $1,55 \pm 0,16$ & $2,85 \pm 0,43$ & $1,63 \pm 0,03$ & $1,76 \pm 0,23$ \\
\hline Pâncreas & $6,46 \pm 0,35$ & $8,66 \pm 0,60$ & $2,24 \pm 0,28$ & $4,76 \pm 0,51$ & $1,10 \pm 0,14$ & $1,77 \pm 0,33$ & $0,52 \pm 0,04$ & $0,50 \pm 0,22$ \\
\hline Fígado & $5,52 \pm 0,65$ & $5,16 \pm 0,29$ & $3,22 \pm 0,52$ & $3,33 \pm 0,81$ & $2,06 \pm 0,13$ & $1,61 \pm 0,44$ & $1,60 \pm 0,38$ & $1,03 \pm 0,13$ \\
\hline Int. Grosso & $7,19 \pm 1,33$ & $5,98 \pm 1,09$ & $2,84 \pm 0,30$ & $3,62 \pm 0,79$ & $1,24 \pm 0,35$ & $1,51 \pm 0,26$ & $0,50 \pm 0,05$ & $0,72 \pm 0,48$ \\
\hline Int. Delgado & $4,82 \pm 0,66$ & $6,14 \pm 1,15$ & $2,53 \pm 0,38$ & $4,72 \pm 1,11$ & $1,03 \pm 0,10$ & $2,53 \pm 0,48$ & $0,89 \pm 0,16$ & $1,35 \pm 0,14$ \\
\hline Músculo & $2,58 \pm 0,20$ & $2,12 \pm 0,56$ & $2,55 \pm 0,67$ & $1,87 \pm 0,71$ & $0,40 \pm 0,10$ & $0,44 \pm 0,10$ & $0,30 \pm 0,06$ & $0,15 \pm 0,01$ \\
\hline Osso & $4,99 \pm 0,27$ & $4,99 \pm 0,60$ & $2,40 \pm 0,27$ & $2,52 \pm 0,64$ & $1,05 \pm 0,27$ & $1,05 \pm 0,09$ & $0,49 \pm 0,08$ & $0,85 \pm 0,03$ \\
\hline Gordura & $4,22 \pm 0,93$ & $2,73 \pm 0,62$ & $3,88 \pm 0,73$ & $1,83 \pm 0,52$ & $1,15 \pm 0,41$ & $1,46 \pm 0,60$ & $1,01 \pm 0,15$ & $0,66 \pm 0,16$ \\
\hline
\end{tabular}

Abreviações: Int. Grosso = Intestino Grosso; Int. Delgado = Intestino Delgado

$\left.{ }^{*}\right)$ GLP-1- $\beta$-Ala-HYNIC- ${ }^{99 m}$ Tc; $\left({ }^{* *}\right)^{99 m}$ Tc-HYNIC- $\beta$-Ala-Exedin4

A radioatividade no estômago e intestine foi calculada após remoção do conteúdo luminal. 
A alta captação nos órgãos e tecidos foi verificada no primeiro tempo estudado de $10 \mathrm{~min}$. Destaca-se a captação alta nos pulmões, assim como observado por Jodal et al. (2014), em um estudo com exendin-4 radiomarcado com gálio-68. Tal fato justifica-se por tratar-se de um órgão altamente vascularizado. A dificuldade em coletar o tecido pulmonar sem a completa remoção do sangue também contribui para os valores de \%DI/g alcançados.

Para o órgão de estudo, o pâncreas, é possível observar alta captação entre 10 e $60 \mathrm{~min}$ p.i. para ambos radiotraçadores. ${ }^{99 \mathrm{~m}} \mathrm{Tc}$-HYNIC- $\beta$-Ala-Exedin4 evidenciou uma maior captação no pâncreas $(p<0,01)$ do que GLP1- $\beta$-Ala-HYNIC${ }^{99 m}$ Tc em 30 e 60 min p.i.

A captação total no sangue, músculo e osso conforme mostra a TAB. 4, demonstra ser superior para o radiotraçador GLP1- $\beta$-Ala-HYNIC- ${ }^{99 \mathrm{~m}} \mathrm{Tc}$, porém com uma depuração rápida e contínua para ambos traçadores.

TABELA 4 - Porcentagem da dose total injetada dos radiomarcados GLP1- $\beta$-AlaHYNIC- ${ }^{99 m}$ Tc e ${ }^{99 m}$ Tc-HYNIC- $\beta$-Ala-Exedin4 em animais controle para diferentes tempos (\%DI).

\begin{tabular}{cccccc}
\hline Órgão/Tecidos & Produtos & $\mathbf{1 0 m i n}$ & $\mathbf{3 0 m i n}$ & $\mathbf{1 h}$ & $\mathbf{2 h}$ \\
\hline \multirow{2}{*}{ Sangue } & $G L P-1$ & $15,06 \pm 1,08$ & $4,17 \pm 0,60$ & $1,62 \pm 0,40$ & $0,70 \pm 0,12$ \\
& Exedin 4 & $12,00 \pm 1,53$ & $9,67 \pm 1,84$ & $3,21 \pm 0,87$ & $0,83 \pm 0,08$ \\
\hline \multirow{2}{*}{ Músculo } & $G L P-1$ & $31,35 \pm 0,23$ & $6,33 \pm 0,85$ & $2,52 \pm 1,28$ & $2,60 \pm 0,70$ \\
& Exedin 4 & $14,91 \pm 1,43$ & $12,52 \pm 1,73$ & $3,89 \pm 0,95$ & $1,36 \pm 0,12$ \\
\hline \multirow{2}{*}{ Osso } & $G L P-1$ & $12,10 \pm 0,59$ & $3,92 \pm 0,56$ & $1,75 \pm 0,57$ & $2,14 \pm 0,39$ \\
& Exedin 4 & $10,55 \pm 1,46$ & $8,78 \pm 1,12$ & $2,31 \pm 0,17$ & $1,97 \pm 0,21$ \\
\hline
\end{tabular}

Os resultados do estudo de biodistribuição para ambos radiotraçadores em animais Swiss controle, obesos, diabéticos e pós-obesos, para o tempo de 1 hora após injeção, estão demonstrados em porcentagem de dose injetada por grama (\%DI/g) nas TAB. 5 e TAB. 6 . Os radioconjugados mostraram perfis similares, para a maioria dos órgãos quando comparados às mesmas condições clínicas. A partir 
dos resultados obtidos é possível observar que os animais controle evidenciaram maior captação nos órgãos de interesse, fígado e pâncreas, comparado aos demais quadros clínicos para ambos radiotraçadores.

TABELA 5 - Biodistribuição do GLP1- $\beta-A l a-H Y N I C-{ }^{99 m}$ Tc (\%DI/g) em camundongos Swiss controle, obeso, diabético e pós-obeso $(n=5)$

\begin{tabular}{lcccc}
\hline $\begin{array}{l}\text { Radiotraçador } \\
\text { Tempo }\end{array}$ & \multicolumn{4}{c}{ GLP1- $\beta-A l a-H Y N I C-{ }^{99 m}$ Tc } \\
1 hora \\
\hline Controle & Obeso & Diabético & Pós-obeso \\
\hline Sangue & $1,22 \pm 0,13$ & $1,05 \pm 0,05$ & $0,56 \pm 0,01$ & $0,99 \pm 0,14$ \\
Coração & $0,81 \pm 0,11$ & $0,35 \pm 0,03$ & $0,30 \pm 0,04$ & $0,35 \pm 0,03$ \\
Pulmão & $2,09 \pm 0,25$ & $1,42 \pm 0,37$ & $0,81 \pm 0,13$ & $1,27 \pm 0,21$ \\
Rins & $61,69 \pm 2,20$ & $76,89 \pm 4,99$ & $83,63 \pm 3,60$ & $80,83 \pm 4,70$ \\
Baço & $1,35 \pm 0,18$ & $0,72 \pm 0,06$ & $0,84 \pm 0,11$ & $0,68 \pm 0,10$ \\
Estomago & $1,55 \pm 0,16$ & $1,97 \pm 0,23$ & $1,47 \pm 0,38$ & $1,78 \pm 0,89$ \\
Pâncreas & $1,10 \pm 0,14^{*}$ & $0,95 \pm 0,13$ & $0,81 \pm 0,10^{*}$ & $1,01 \pm 0,12$ \\
Fígado & $2,06 \pm 0,13^{*}$ & $1,09 \pm 0,15^{*}$ & $1,33 \pm 0,23^{*}$ & $1,36 \pm 0,32$ \\
Intestino Grosso & $1,24 \pm 0,35$ & $1,06 \pm 0,08$ & $0,70 \pm 0,04$ & $0,64 \pm 0,07$ \\
Intestino Delgado & $1,03 \pm 0,10$ & $1,15 \pm 0,30$ & $0,93 \pm 0,09$ & $0,86 \pm 0,09$ \\
Músculo & $0,40 \pm 0,10$ & $0,25 \pm 0,04$ & $0,24 \pm 0,04$ & $0,27 \pm 0,02$ \\
Osso & $1,05 \pm 0,27$ & $0,41 \pm 0,08$ & $0,52 \pm 0,11$ & $0,17 \pm 0,05$ \\
Gordura & $1,15 \pm 0,41$ & $0,12 \pm 0,04$ & $1,25 \pm 0,24$ & $0,09 \pm 0,01$ \\
\hline
\end{tabular}

$\mathrm{DP}=$ Desvio-padrão

${ }^{*}=p<0,01$

TABELA 6 - Biodistribuição do ${ }^{99 \mathrm{~m}} \mathrm{Tc}$-HYNIC- $\beta$-Ala-Exedin4 (\%DI/g) em camundongos Swiss controle, obeso, diabético e pós-obeso $(n=5)$

\begin{tabular}{lcccc}
\hline $\begin{array}{l}\text { Radiotraçador } \\
\text { Tempo }\end{array}$ & \multicolumn{5}{c}{$\begin{array}{c}{ }^{99 m} \text { Tc-HYNIC- } \beta \text { Ala-Exedin4 } \\
\text { 1 hora }\end{array}$} \\
\hline & Controle & Obeso & Diabético & Pós-obeso \\
\hline Sangue & $1.02 \pm 0,41$ & $0.62 \pm 0,10$ & $0.36 \pm 0,06$ & $0.54 \pm 0,06$ \\
Coração & $0.96 \pm 0,17$ & $0.40 \pm 0,06$ & $0.37 \pm 0,11$ & $0.28 \pm 0,07$ \\
Pulmão & $5.50 \pm 0,71$ & $5.13 \pm 0,86$ & $2.02 \pm 0,11$ & $3.68 \pm 0,17$ \\
Rins & $47.72 \pm 4,83$ & $66.19 \pm 1,98$ & $37.06 \pm 5,46$ & $68.58 \pm 6,66$ \\
Baço & $1.40 \pm 0,50$ & $0.49 \pm 0,03$ & $0.25 \pm 0,08$ & $0.56 \pm 0,11$ \\
Estomago & $2.85 \pm 0,43$ & $2.15 \pm 0,37$ & $1.94 \pm 0,33$ & $2.28 \pm 0,18$ \\
Pâncreas & $1.77 \pm 0,33^{*}$ & $1.16 \pm 0,05$ & $0.90 \pm 0,06^{*}$ & $1.29 \pm 0,14$ \\
Fígado & $1.61 \pm 0,44^{*}$ & $0.56 \pm 0,07^{*}$ & $0.65 \pm 0,07^{*}$ & $0.76 \pm 0,09$ \\
Intestino Grosso & $1.51 \pm 0,26$ & $1.29 \pm 0,07$ & $0.91 \pm 0,07$ & $1.01 \pm 0,23$ \\
Intestino Delgado & $2.53 \pm 0,48$ & $1.40 \pm 0,10$ & $0.48 \pm 0,09$ & $1.15 \pm 0,19$ \\
Músculo & $0.44 \pm 0,10$ & $0.33 \pm 0,04$ & $0.15 \pm 0,01$ & $0.17 \pm 0,04$ \\
Osso & $1.05 \pm 0,09$ & $0.44 \pm 0,10$ & $0.36 \pm 0,05$ & $0.43 \pm 0,08$ \\
Gordura & $1.46 \pm 0,60$ & $0.10 \pm 0,01$ & $1.49 \pm 0,09$ & $0.11 \pm 0,03$ \\
\hline DPra & & & & \\
\end{tabular}

$\mathrm{DP}=$ Desvio-padrão

${ }^{*}=p<0,01$ 


\subsection{Determinação da ligação às proteínas plasmáticas}

O teste de ligação às proteínas plasmáticas realizado demonstrou uma ligação decrescente com o tempo para ambos os radiotraçadores, atingindo os valores às $2 \mathrm{~h}$ de 47,64 $\pm 1,36$ para o ${ }^{99 \mathrm{~m}} \mathrm{Tc}$-HYNIC- $\beta$-Ala-Exedin4 e 24,79 $\pm 1,03$ para o GLP1- $\beta$-Ala-HYNIC- ${ }^{99 \mathrm{~m}}$ Tc (TAB. 7).

TABELA 7 - Ligação às proteínas plasmáticas do ${ }^{99 \mathrm{~m}}$ Tc-HYNIC- $\beta$-Ala-Exedin4 e GLP1- $\beta$-Ala-HYNIC- ${ }^{99 m} \mathrm{Tc}(\mathrm{n}=3)$.

\begin{tabular}{cccccc}
\hline & Radiotraçador & $\mathbf{1 0} \mathbf{~}$ in & $\mathbf{3 0} \mathbf{~ m i n}$ & $\mathbf{1 h}$ & $\mathbf{2 h}$ \\
\hline \% lig. & Exedin4 & $51,61 \pm 1,16$ & $27,39 \pm 1,99$ & $25,98 \pm 2,28$ & $24,79 \pm 1,03$ \\
proteínas & GLP1 & $89,48 \pm 4,80$ & $85,37 \pm 7,34$ & $69,11 \pm 4,77$ & $47,64 \pm 1,36$ \\
\hline
\end{tabular}

Abreviações: \% lig. proteínas = porcentagem de ligação de proteínas

Para o tempo de $1 \mathrm{~h}$, pode-se verificar que houve maior ligação às proteínas plasmáticas para o traçador GLP1-- $\beta$-Ala-HYNIC comparado ao HYNIC-- $\beta$ Ala-Exedin4. Assim, uma fração maior de HYNIC-- $\beta$-Ala-Exedin4 permaneceu livre para se ligar aos receptores dos órgãos de interesse, resultando em uma captação mais elevada nestes órgãos quando comparado ao outro radiotraçador.

\subsection{Análise histológica de órgãos e tecido}

As fotos dos cortes histológicos do fígado e pâncreas de animais controle, obeso, diabético e pós-obeso estão representadas nas FIG. 19 e 20, respectivamente.

Segundo o laudo obtido da avaliação histopatológica do camundongo Swiss controle, para o fígado a análise microscópica revelou no citoplasma dos hepatócitos vacuolização discreta a moderada difusa e congestão discreta a moderada. Para o pâncreas é possível observar congestão discreta a moderada e o tecido adiposo não apresenta alterações. 
A avaliação histopatológica do fígado de camundongo Swiss obeso revelou no citoplasma dos hepatócitos vacuolização moderada difusa e congestão discreta a moderada. No pâncreas pode-se observar congestão discreta e alterações no diâmetro das células das ilhotas pancreáticas.

O laudo obtido da avaliação histopatológica para o fígado de camundongo Swiss diabético revelou congestão moderada e hepatócitos com citoplasma abundante e claro. Para o pâncreas é possível observar congestão discreta e atrofia das ilhotas pancreáticas multifocal.

O laudo referente à avaliação histopatológica do fígado do animal pósobeso revelou no citoplasma dos hepatócitos vacuolização discreta a moderada difusa e congestão moderada. Para o pâncreas é possível observar congestão discreta a moderada e sem alterações dignas de nota. É possível verificar que o laudo da análise microscópica do animal pós-obeso é similar ao controle, evidenciando que não houve alterações a nível celular.

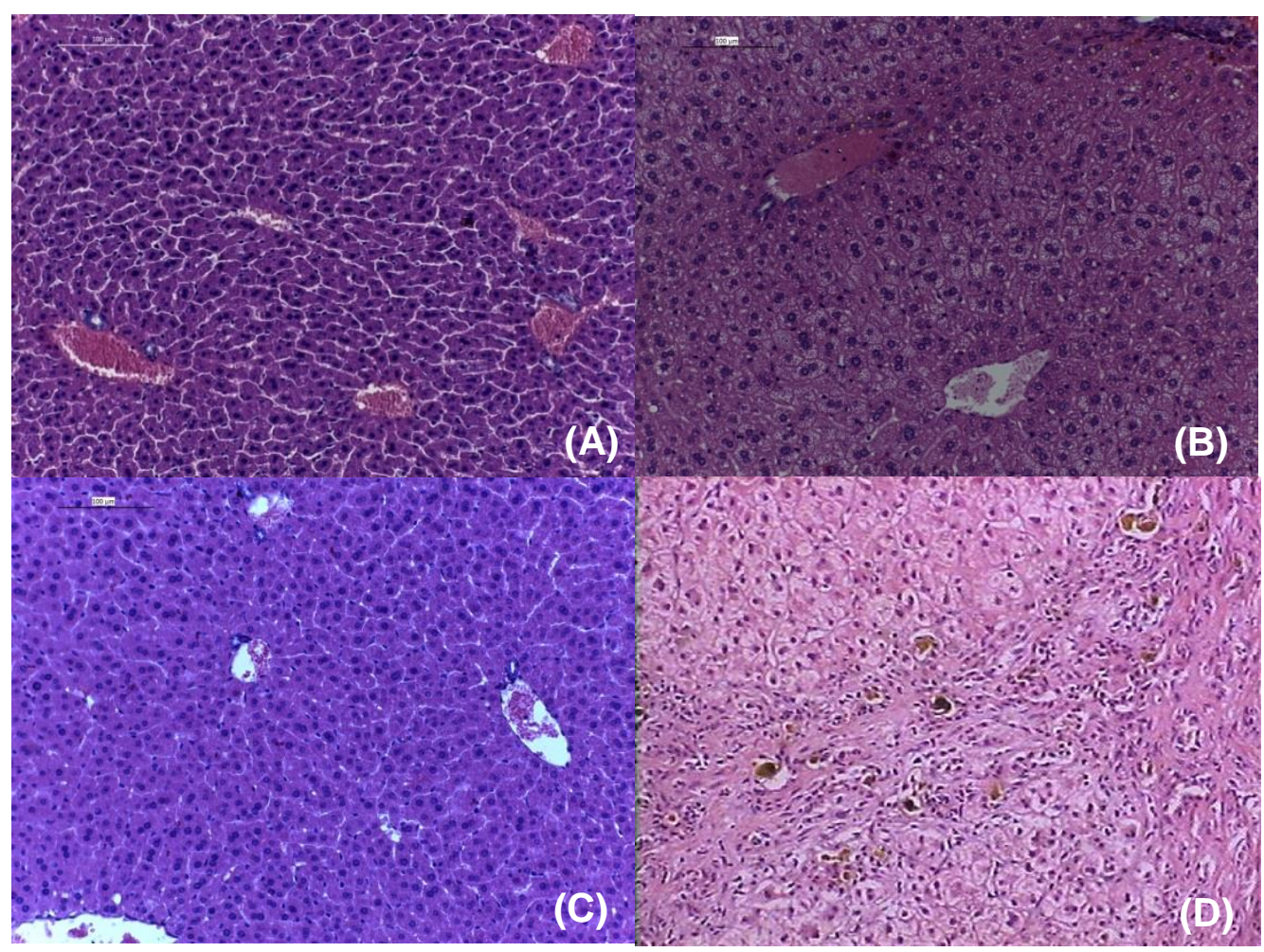

FIGURA 19 - Cortes histológicos do fígado de camundongo Swiss (A) controle; (B) obeso; (C) diabético; (D) pós-obeso, aumento de $20 \mathrm{X}$. 


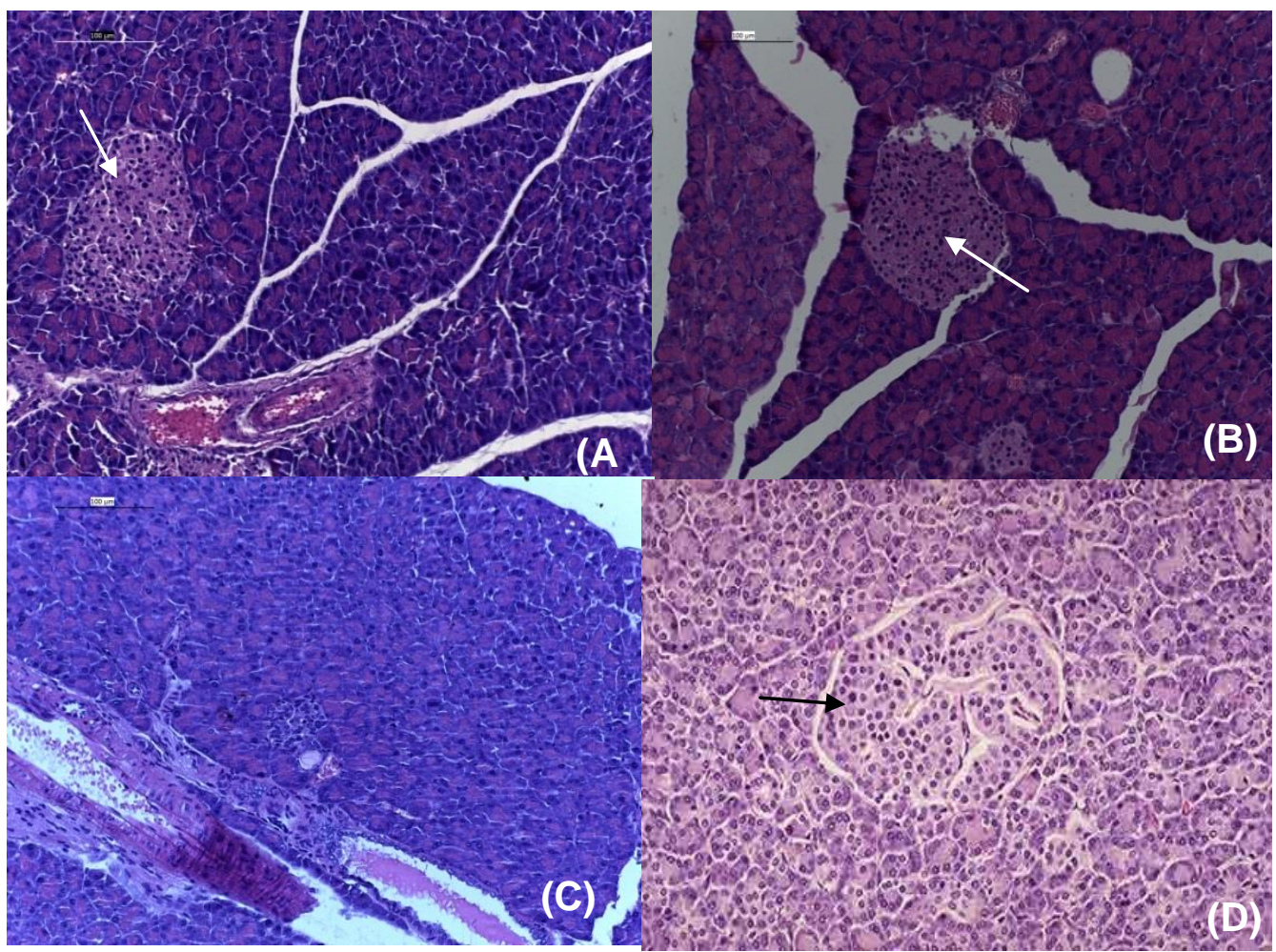

FIGURA 20 - Cortes histológicos do pâncreas de camundongo Swiss (A) controle; (B) obeso; (C) diabético; (D) pós-obeso, aumento de 20 X. Seta indica células beta pancreáticas na Ilhota de Langerhans.

\subsection{Quantificação ex-vivo por meio de imagens cintilográficas}

Os valores de captação ex-vivo nos órgãos fígado, pâncreas, intestino grosso, intestino delgado e coração dos animais controle, obesos, diabéticos e pósobesos, realizados em gama-câmara e calculados a partir da dose injetada (em seringa) encontram-se nas TAB 8 e TAB. 9.

Pode-se observar que o fígado apresenta a maior captação comparado aos demais. Ressalta-se que o valor calculado equivale à porcentagem da dose injetada (\%DI).

Nota-se nas FIG.21 e 22, as imagens ex vivo dos órgãos fígado, pâncreas, coração e intestino (delgado e grosso), realizadas em gama câmara para ambos radiomarcadores no tempo de $1 \mathrm{~h}$ p.i. 
TABELA 8 - Quantificação das captações em regiões de interesse (ROI) de camundongos Swiss controle.

\begin{tabular}{cccccc}
\hline \multirow{2}{*}{ Órgãos } & \multirow{2}{*}{ Radiotraçador } & \multicolumn{4}{c}{ Tempo após injeção } \\
& & $\mathbf{1 0 m i n}$ & $\mathbf{3 0 m i n}$ & $\mathbf{1 h}$ & $\mathbf{2 h}$ \\
\hline \multirow{2}{*}{ Fígado } & GLP-1 & $2,31 \%$ & $1,13 \%$ & $0,62 \%$ & $0,88 \%$ \\
& Exedin 4 & $2,51 \%$ & $1,53 \%$ & $0,60 \%$ & $0,70 \%$ \\
\hline \multirow{2}{*}{ Pâncreas } & GLP-1 & $0,08 \%$ & $0,08 \%$ & $0,01 \%$ & $0,01 \%$ \\
& Exedin 4 & $0,34 \%$ & $0,17 \%$ & $0,15 \%$ & $0,06 \%$ \\
\hline \multirow{2}{*}{ Int. Grosso } & GLP-1 & $0,53 \%$ & $0,15 \%$ & $0,08 \%$ & $0,08 \%$ \\
& Exedin 4 & $0,34 \%$ & $0,36 \%$ & $0,18 \%$ & $0,15 \%$ \\
\hline \multirow{2}{*}{ Int. } & GLP-1 & $0,53 \%$ & $0,22 \%$ & $0,10 \%$ & $0,09 \%$ \\
Delgado & Exedin 4 & $0,80 \%$ & $0,41 \%$ & $0,46 \%$ & $0,20 \%$ \\
\hline \multirow{2}{*}{ Coração } & GLP-1 & 0,11 & $0,05 \%$ & $0,03 \%$ & $0,03 \%$ \\
& Exedin 4 & $0,13 \%$ & $0,09 \%$ & $0,02 \%$ & $0,03 \%$ \\
\hline
\end{tabular}

TABELA 9 - Quantificação das captações em regiões de interesse (ROI) de camundongos Swiss obesos, diabéticos e pós-obesos para o tempo de 1 hora p.i.

\begin{tabular}{ccccc}
\hline \multirow{2}{*}{ Órgãos } & \multirow{2}{*}{ Radiotraçador } & \multicolumn{3}{c}{ Tempo após injeção: 1hora } \\
& & Obesos & Diabéticos & Pós-obesos \\
\hline \multirow{2}{*}{ Fígado } & GLP-1 & $0,47 \%$ & $1,02 \%$ & $1,12 \%$ \\
& Exedin 4 & $0,53 \%$ & $1,10 \%$ & $1,00 \%$ \\
\hline \multirow{2}{*}{ Pâncreas } & GLP-1 & $0,07 \%$ & $0,10 \%$ & $0,03 \%$ \\
& Exedin 4 & $0,09 \%$ & $0,11 \%$ & $0,21 \%$ \\
\hline Int. & GLP-1 & $0,21 \%$ & $0,53 \%$ & $0,16 \%$ \\
Grosso & Exedin 4 & $0,19 \%$ & $0,09 \%$ & $0,30 \%$ \\
\hline \multirow{2}{*}{ Int. } & GLP-1 & $0,05 \%$ & $0,18 \%$ & $0,06 \%$ \\
Delgado & Exedin 4 & $0,06 \%$ & $0,39 \%$ & $0,12 \%$ \\
\hline \multirow{2}{*}{ Coração } & GLP-1 & $0,07 \%$ & $0,08 \%$ & $0,07 \%$ \\
& Exedin 4 & $0,11 \%$ & $0,15 \%$ & $0,01 \%$ \\
\hline
\end{tabular}




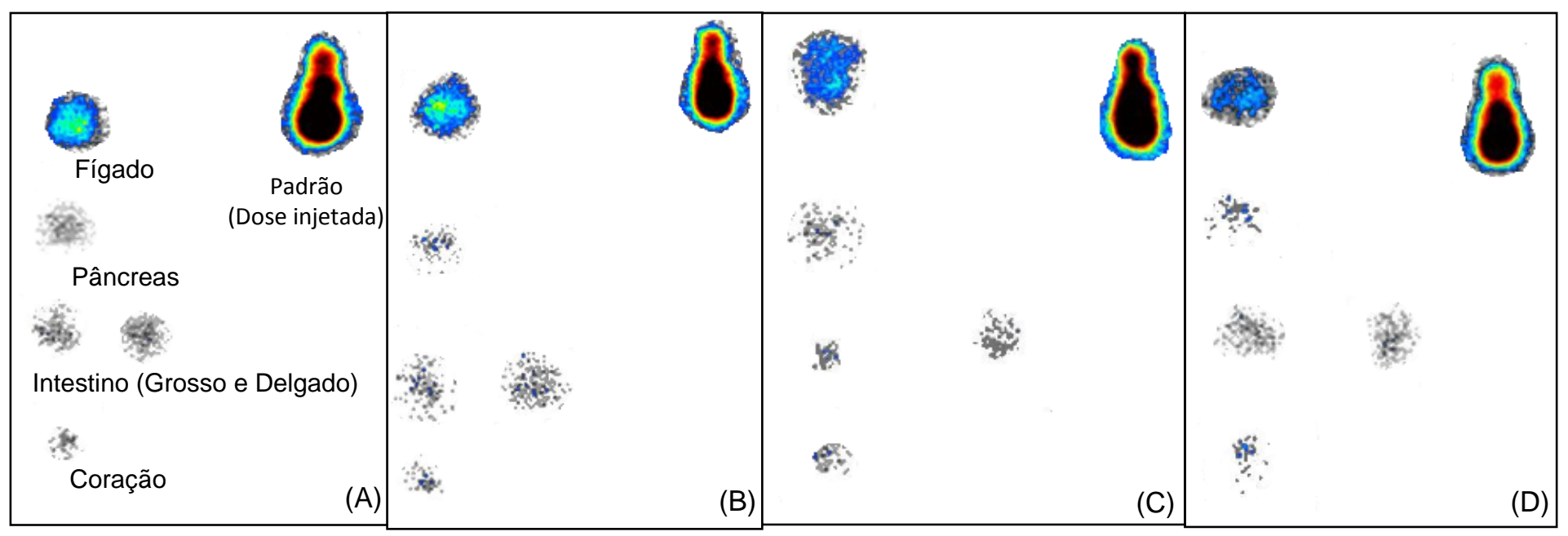

FIGURA 21 - Imagens ex vivo nos 4 grupos de animais: controle (A), obeso (B), diabético (C) e pós-obeso (D) para o tempo de 60 min p.i. do GLP1- $\beta$-Ala-HYNIC${ }^{99 m} \mathrm{Tc}$.

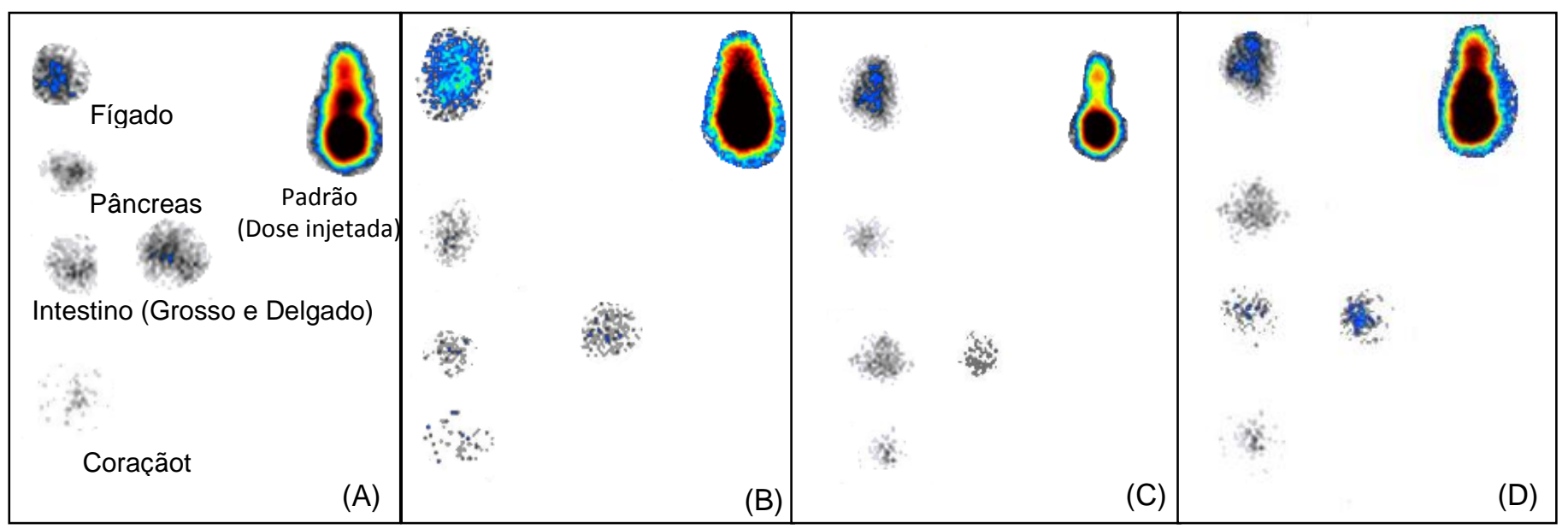

FIGURA 22 - Imagens ex vivo nos 4 grupos de animais: controle (A), obeso (B), diabético (C) e pós-obeso (D) para o tempo de 60 min p.i. do HYNIC-- $\beta$-Ala-Exedin4. 


\section{DISCUSSÃO}

A obesidade está relacionada a uma série de doenças crônico-degenerativas (dentre as quais o Diabetes Mellitus tipo 2). A relação entre diabetes e obesidade é bastante visível. $O$ diabetes do tipo 2 é uma doença crônica caracterizada por níveis elevados de açúcar no sangue.

As células beta têm uma participação crucial nas doenças crônicas não transmissíveis citadas acima (AMOUYAL e ANDREELLI, 2016; SALEHI et al., 2014; SISTA et al., 2016; MARRIF e AL-SUNOSI, 2016). Barreiras técnicas e anatômicas tem retardado a implementação de técnicas diagnósticas das ilhotas de Langerhans. Estudos metabólicos, que são mais utilizados na prática clínica, podem não refletir com precisão os danos às células beta.

A Comissão Européia lançou recentemente "Tratamentos inovadores paro diabetes", incluindo entre eles, diagnósticos não invasivos para medida da Massa das Células Beta (MCB) in vivo. Concluíram que a ultrasonografia e tomografia computadorizada tem pouca especificidade e outros métodos como fluorescência e ressonância magnética também apresentam restrições (LAURENT et al., 2016).

O presente trabalho pretendeu, de forma inédita, desenvolver um radiotraçador de conjugado de incretina marcado com tecnécio a fim de propor um método não invasivo de monitoração de células beta pancreáticas em enfermos acometidos por obesidade e diabetes. Além de descrever os perfis de radiotracadores de incretina em estudo de obesidade induzida e obesidade revertida pela dieta.

O tecnécio é ainda o radionuclídeo para diagnósticos mais amplamente disponível e de fácil marcação, sem necessidade de purificação, fazendo com que traçadores marcados por ${ }^{99 \mathrm{~m}} \mathrm{Tc}$ sejam adequados para produção em massa de kits 
que podem ser distribuídos e usados em hospitais e clínicas onde haja um gerador do radionuclídeo presente (EBENHAN et al., 2014). Coligantes são necessários para completar a esfera de coordenação do núcleo de tecnécio, porque o HYNIC só pode ocupar uma ou duas posições no radionuclídeo (FAINTUCH et al., 2005). No grupo de diferentes coligantes, tricina e EDDA são os que têm a melhor eficiência de radiomarcação.

O agente quelante bifuncional, assim como o espaçador, são comumente usados em procedimento de radiomarcação para melhorar a estabilidade. $O$ quelante bifuncional ácido hidrazinonicotínico (HYNIC) já foi usado para radiomarcação de biomoléculas com ${ }^{99 \mathrm{~m}} \mathrm{Tc}$, e as características desse método de marcação já estão bem estabelecidas (ERFANI et al., 2014; FAINTUCH et al., 2005; GUO et al., 2014; MESZAROS et al., 2010).

A farmacocinética dos complexos radiomarcados com ${ }^{99 \mathrm{~m}} \mathrm{Tc}$ pode ser favorecida com o uso de espaçadores entre o radioisótopo e o agente quelante bifuncional.

As moléculas de incretina, dirigidas a receptores de glucagon, principalmente antagonistas como Exendin-4, demonstraram especificidade como marcadores (MI et al., 2016; BANDARA et al., 2016; WU et al., 2014; MEIER e BONADONNA, 2013; LEHTONEN et al., 2015), pois são resistentes a exo e endo-peptidases.

Grande parte da sua superioridade em relação ao GLP-1, está relacionada com a região helicoidal central e as sequências contrastantes de Leu10-Gly30 em Exendin-4 versus Val16-Arg36 em GLP-1 (RUNGE et al., 2007).

O sítio de ligação do quelante, no caso dos radiomarcadores ${ }^{99 \mathrm{~m}} \mathrm{Tc}$, pode influenciar a farmacocinética e a afinidade de ligação também. Em vários protocolos, o quelante (principalmente DOTA) é ligado a Lys40. Na presente investigação, HYNIC foi anexado ao terminal $\mathrm{N}$ da Exendina-4, devido à importância funcional da sequência PSSGAPPPS, para a afinidade $\mathrm{N}$-terminal para o receptor alvo (MANN et al., 2010).

Num estudo piloto, fez-se radiomarcação de GLP1- $\beta$ Ala-HYNIC- ${ }^{99 m}$ Tc e ${ }^{99 m}$ TcHYNIC- $\beta$ Ala-Exedina4 utilizando a troca de coligantes EDDA-tricina (dados não apresentados), resultando num perfil baixo. Usando apenas tricina como coligante 
para completar a esfera de coordenação do núcleo de tecnécio (V), obteve-se um maior rendimento, com boa estabilidade radioquímica.

Todas as moléculas foram radiomarcadas de acordo com as melhores condições previamente estabelecidas pelo nosso grupo. Neste sentido, foi obtido elevado rendimento radioquímico (> 95\%) para os dois radiomarcados.

O coeficiente de partição é uma medida da lipofilicidade de um composto e é definido como a razão da concentração do mesmo, no equilíbrio, após dissolução em um sistema de duas fases formadas por dois solventes imiscíveis, como por exemplo, a água e o octanol (SILVA e FERREIRA, 2003). Ele também é um fator importante na farmacocinética do fármaco dependendo da sua característica hidrofílica ou lipofílica (KOTHARI et al., 2003).

Usualmente, o valor do coeficiente final é expresso em $\log P$. Valores positivos confirmam a lipofilicidade do composto, assim como valores negativos a hidrofilicidade. Ambos os radiotraçadores são hidrofílicos com valores de log $P$ negativos. A hidrofilicidade dos radiotraçadores também se deve a utilização do agente quelante HYNIC e da beta alanina como espaçador.

A hidrofilicidade favorece uma depuração rápida da droga via excreção renal, favorecendo a visualização por imagem do órgão de interesse em tempos precoces (ZHANG et al., 2002).

Os trabalhos utilizando modelos de diabetes experimental em roedores têm sido amplamente utilizados na reprodução da sintomatologia do DM, uma vez que esses animais apresentam semelhanças clínicas, laboratoriais e histológicas com o diabetes humano.

O diabetes experimental pode ser induzido em animais, por vários mecanismos. Infelizmente, porém, em grande número de métodos, o agente utilizado não é capaz de desenvolver a maior parte da fisiopatologia do diabetes humano.

Desta forma tonam-se imprescindíveis estudos envolvendo modelos experimentais de Diabetes Mellitus, que forneçam informações que possam ser úteis 
no desenvolvimento de procedimentos mais eficazes na prevenção e no tratamento da doença.

A pancreatectomia total consiste em método clássico de obtenção de diabetes experimental. A ressecção parcial do pâncreas também produz diabetes, A utilização desses métodos de ressecção, entretanto, tem sido restrita principalmente a animais de maior porte, além de incorrer necessariamente num procedimento cirúrgico adicional, com todas as suas implicações.

A utilização de hormônios com efeitos antagônicos à insulina, incluindo a epinefrina, o glucagon, os glicocorticoides e o hormônio de crescimento, ainda que capazes de produzir hiperglicemia, como na resposta fisiológica ao estresse, ou em certas condições patológicas (tumores, distúrbios metabólicos), tem seus efeitos discutíveis em animais, exercendo, principalmente no caso da epinefrina e do glucagon, um efeito antiinsulínico, somente se administrados em altas doses (LERCO et al., 2003).

Vários estudos têm reportado a indução de hiperglicemia e hiperplasia das células beta em camundongos, ratos, coelhos, cobaias e macacos por meio da exposição à hidrocortisona e ACTH (HAUSBERGER e RANSAY, 1959; CAVELLERO e MOSCA, 1953; ABELOVE e PASCHIKS, 1954; KERNS e LOGOTHETOPOULOS, 1970; LIKE e CHICK, 1974). Os eventos bioquímicos, hormonais e morfológicos do diabetes, assim induzido, são, contudo, muito variáveis, o que comprometeria a avaliação da doença.

A utilização de modelos virais para o diabetes experimental, relacionados aos vírus RNA, altamente espécie-específicos, além de se constituírem em risco potencial para o experimentador, tem ainda papel incerto na patogênese da doença.

Os métodos químicos de supressão endócrina do pâncreas, os quais exibem todos os eventos bioquímicos, hormonais e morfológicos que ocorrem durante e após a indução do estado diabetogênico é realizada através do uso de substâncias que destroem seletivamente as células beta do pâncreas, produtoras de insulina. A aloxana e a estreptozotocina são os dois agentes químicos, com citotoxicidade específica para as células beta, mais estudados. Essas drogas causam insuficiência 
insulínica primária do pâncreas, provocando uma resposta trifásica nos níveis glicêmicos durante as primeiras horas da administração, seguida do estabelecimento de diabetes permanente nas 24 horas subsequentes. Ambas são citotóxicas, análogos da glicose e, embora as suas citotoxicidades ocorram através de diferentes mecanismos, o modo de captação de ambas as substâncias pelas células beta do pâncreas é o mesmo, ocorrendo através do transportador de glicose do tipo GLUT 2 (SILVA et al., 2004; LENZEN, 2008; ETUK, 2010).

Esses métodos químicos, apesar de terem um elevado índice de mortalidade relativa, são de fácil execução e permitem a utilização de um grande número de animais, destruindo a parte endócrina do pâncreas, com preservação de sua função exócrina (LERCO et al., 2003).

A estreptozotocina (EZT) é um agente quimioterápico, utilizado no tratamento de tumores carcinoides e endócrinos do pâncreas. Atua por meio da diminuição da ação da adenina-nicotinamida das células $\beta$-pancreáticas, inibindo a síntese de DNA, consequentemente, bloqueando de forma irreversível a produção de insulina. A EZT causa grave hiperglicemia, induzindo o DM em animais, semelhante ao diabetes tipo 1 em humanos (CARVALHO et al., 2003).

A aloxana (ALX) tem sido amplamente utilizada como droga diabetogênica (MACHADO et al., 2009). Esta droga é hidrofílica e não estável. Sua meia-vida em $\mathrm{pH}$ neutro e temperatura de $37^{\circ} \mathrm{C}$ é aproximadamente 1,5 min podendo-se prolongar em temperaturas baixas. A ALX é uma substância que possui, comprovadamente, ação seletiva e destrutiva sobre as células $\beta$ pancreáticas quando em doses adequadas e distorção da citoarquitetura das ilhotas, além de distribuição irregular de outras células pancreáticas. Devido à intensa estimulação pelas quais as células $\beta$ estão sujeitas, elas raramente sofrem mitose (SCHOSSLER et al., 2004) Embora todas as células beta sofram danos ao longo do tempo, as células alfa e delta permanecem intactas, assim como as células do parênquima exócrino não são afetadas pela aloxana (DORNAS et al., 2006).

O mecanismo de ação da aloxana inicia-se com discreta redução glicêmica cerca de 30 minutos após sua injeção, como resultado de estimulação da secreção 
de insulina e consequente aumento da insulinemia. Contudo, após 60 minutos da injeção ocorre hiperglicemia decorrente de decréscimo da insulinemia persistindo nas próximas 4 horas, ocorrendo nessa fase as primeiras alterações morfológicas das células $\beta$, como dilatação do retículo endoplasmático rugoso e das mitocôndrias, além de diminuição do complexo de Golgi, dos grânulos e do conteúdo de insulina. No período de 4 a 8 horas ocorre grande aumento da insulinemia, como consequência de ruptura da membrana celular. Posterior e permanentemente segue a hiperglicemia, que ocorre de forma crescente entre 9 a 144 horas, estabilizando-se em seguida. Esta fase é alcançada com a completa desgranulação e perda de integridade das células beta, ocorrendo aumento da presença de macrófagos no pâncreas (SZKUDELKI, 2001; LENZEN, 2008; LEME et al., 2010).

Estas breves alterações são de fundamental importância para o desenvolvimento do quadro diabético no animal que, em longo prazo, incluem redução no peso, polifagia, polidipsia e alterações no sistema imunológico (LEME et al., 2010; MOURA et al., 2012).

Alguns estudos demonstraram que a formação de radicais superóxido e hidroxila, induzidos por aloxana, é responsável pela citotoxicidade desse composto. Outros experimentos sugerem que a inibição da secreção de insulina por aloxana é causada por sua interferência com as proteínas citoplasmáticas que contêm sulfidril e dissulfide (LIMA et al., 2001).

Embora muitos estudiosos relatam pouco ou nenhuma anormalidade do fígado em diabetes por aloxana, um similar consumo de aloxana ocorre neste órgão. Entretanto, este e outros tecidos são mais resistentes a espécies de oxigênio reativas em comparação com as células beta pancreáticas, protegendo contra a toxicidade da aloxana (DORNAS et al., 2006).

Segundo Lenzen (2008) ambos os agentes químicos, aloxana e estreptozotocina, induzem uma deficiência da produção de insulina pela morte das células beta. Embora os mecanismos de captação de ambas as substâncias pelas células beta pancreáticas via transportadores de glicose GLUT2 e resultante morte das mesmas por necrose sejam idênticos, a ação tóxica da aloxana é mediada via 
espécies reativas de oxigênio, e da estreptozotocina via alquelação do DNA das células beta.

Outro aspecto a considerar são as vias de administração da droga. A via endovenosa tem sido a de escolha na maioria das espécies animais, onde os efeitos da aloxana são mais evidentes. As vias subcutânea e intraperitoneal também são satisfatórias no roedor. Finalmente, a via oral é usualmente insatisfatória para a ação da aloxana, muito embora o diabetes possa ser produzido em ratos, coelhos e gatos, se a droga for rapidamente ingerida com comida, após um jejum prévio prolongado (SOARES et al., 2000; LERCO et al., 2003; ETUK, 2010). A dose requerida para indução de diabetes depende da espécie animal, rota de administração e estado nutricional (SZKUDELSKI, 2001).

Baixas concentrações de aloxana $(0,5 \mathrm{mM}$ ou $1 \mathrm{mM})$ não ocasionam necrose, sendo que 2,5 mM de aloxana desencadeiam $50 \%$ de necrose nas células beta. Essa concentração atinge as células beta localizadas no centro das ilhotas, já as células periféricas maiores permanecem intactas. Com concentrações de $5 \mathrm{mM}$, a aloxana é capaz de destruir a maioria das células beta de diferentes tamanhos. Em relação à repetição de pequenas doses de aloxana, as quais são ineficazes separadamente, essas podem conduzir à diabetes levando ao significante aumento da mortalidade das células beta (FEDERIUK et al., 2004).

No presente trabalho utilizou-se a aloxana como droga para indução de diabetes em camundongos Swiss, cuja atividade diabetogênica foi inicialmente notada por Dunn et al. (1943), quando estudava os efeitos do ácido úrico e seus derivados na produção da lesão renal em coelhos. A escolha desta droga se deu devido a duas razões: a primeira, de ordem econômica, dado o alto custo da estreptozotocina, quando comparado com o da aloxana; a segunda, pelo uso amplamente difundido da aloxana na produção de diabetes experimental por inúmeros trabalhos presentes na literatura científica (PERES et al., 2009; ETUK, 2010; KIKUMOTO et al., 2010; MOURA et al., 2012; SHARMA et al., 2014)

O presente estudo mostrou aumento da glicemia 72 horas após aplicação, demonstrando haver lesão celular e perda da massa das células $\beta$. Contudo, as primeiras 24 horas são de fundamental importância para as alterações encontradas 
no quadro diabético aloxânico. Isto porque a glicemia sofre bruscas mudanças durante a ação da aloxana, um processo tetrafásico, que compreende incialmente diminuição da glicose sérica por cerca de 30 minutos, causada por estímulo da secreção insulínica. Posteriormente ocorre retenção da insulina nas células $\beta$ e consequente aumento da glicemia, que dura até 4 horas após a aplicação da droga. A dilatação do retículo endoplasmático rugoso e das mitocôndrias e a diminuição do complexo de Golgi e dos grânulos são as primeiras alterações morfológicas nas células $\beta$. A fase seguinte é a ruptura da membrana celular induzida pela aloxana, que causa um grande aumento da insulinemia. Nesta fase, é necessário que o animal ingira glicose, para evitar hipoglicemia severa. A quarta e última fase é a encontrada no animal de forma permanente com completa lise das células e redução da massa de células $\beta$, hipoinsulinemia e hiperglicemia (LEME et al., 2010).

Conforme Etuk (2010), são considerados camundongos diabéticos, apenas aqueles animais que apresentarem valores de glicemia superiores a $180 \mathrm{mg} / \mathrm{dl}$. $O$ modelo experimental de indução de diabetes pela aloxana utilizado neste trabalho comprovou que a mesma agiu na provável destruição das células beta dos animais a julgar pelo aumento significativo da glicemia de jejum dos camundongos induzidos (acima de 500 mg/dl) em relação à glicemia dos animais normais, caracterizando um modelo de diabetes tipo 1.

É possível observar que os resultados obtidos para o aumento significativo das concentrações séricas de glicose nos camundongos pós-injeção intraperitoneal de aloxana no presente trabalho foi concordante com os encontrados na literatura (LERCO et al., 2003; SCHOSSLER et al., 2004; PERES et al., 2009; LEME et al., 2010; KIKUMOTO et al., 2010; SHARMA et al., 2014).

Para melhor compreender o papel de cada um dos elementos envolvidos na fisiopatologia da obesidade e suas comorbidades, assim como fornecer subsídios que possibilitem o surgimento de novas proposições terapêuticas para o tratamento dessa doença, os pesquisadores utilizam-se, cada vez mais, de modelos experimentais obtidos a partir de indução por dieta hiperlipídica, uma vez que esse modelo reflete de forma mais similar às alterações metabólicas encontradas na obesidade humana (WEST e YORK, 1998; WINZELL e AHRÉN, 2004). 
Em animais de laboratório, a gênese da obesidade está relacionada, em sua maioria, com mutações genéticas, porém esse modelo é muito distante do encontrado nos humanos. A adoção de dietas hipercalóricas ou hiperlipídicas vem sendo utilizada como modelo de indução da obesidade em animais, devido a sua semelhança com a gênese e as respostas metabólicas decorrentes da obesidade em humanos. Existem diferentes modelos de animais, geralmente roedores, que desenvolvem a obesidade a partir de mutações genéticas. Entretanto, considerando que o modelo deve ser o mais próximo possível da gênese da obesidade em humanos, a indução dessa condição via consumo de alimentos altamente palatáveis e com alto valor energético parece ser o mais apropriado. Ou seja, a obesidade é a consequência de um balanço energético positivo gerado por fatores ambientais, como por exemplo, o consumo em excesso de alimentos altamente calóricos e o sedentarismo (TSCHOP e HEIMAN, 2001).

Os animais comumente utilizados para esse modelo de indução são os camundongos, sendo as linhagens isogênicas ou inbred (C57BL/6, C57BL/6J, $A K R / J, A / J)$ mais amplamente utilizadas. Esse tipo de linhagem é obtido a partir do cruzamento de animais consanguíneos, permitindo a criação de populações estáveis e geneticamente homogêneas, o que não condiz com a reprodução humana (FERREIRA et al., 2005; WEST et al., 1992). Em função disso, camundongos heterogêneos ou outbred (Swiss), obtidos a partir do cruzamento ao acaso, podem mais facilmente manter variabilidade genética similar à encontrada na população humana. Além disso, estes últimos possuem menor custo de reprodução e manutenção, favorecendo sua utilização (WEST et al., 1992; RICE e O'BRIEN, 1980).

Vários modelos experimentais de obesidade foram desenvolvidos com o intuito de auxiliar na compreensão da fisiopatologia da obesidade. Dietas hipercalóricas têm sido comumente utilizadas em ensaios experimentais de obesidade, objetivando mimetizar efeitos orgânicos associados à adiposidade (BOUSTANY et al., 2005; DU TOIT et al., 2005; CARROLL et al., 2006).

A promoção de obesidade em roedores a partir de dietas hiperlipídicas (DH) almeja reproduzir o comportamento nutricional humano (DINIZ et al., 2008). Além 
disso, tem sido demonstrado que as perturbações originadas por uma alimentação com alto teor de gordura em roedores se assemelham às perturbações metabólicas observadas em humanos (WOODS et al., 2003).

Em 1949, a obesidade foi induzida pela dieta pela primeira vez em ratos alimentados com uma dieta palatável semi-líquida (Ingle, 1949). Então, em 1953, Fenton e Dowling utilizando dieta rica em gorduras, com $50 \%$ de gordura da energia total, em camundongos recém-desmamados para induzir obesidade, chamada de obesidade nutricional (FENTON e DOWLING, 1953), mas o modelo foi mais tarde rebatizado de obesidade dietética (SCLAFANI e SPRINGER, 1976).

Um aspecto importante na validação do modelo de indução de obesidade por ingestão de dieta hiperlipídica, se refere à eficiência energética da dieta. Prior et al. (2008) e Townsend et al. (2008) constataram que uma maior eficiência energética foi encontrada no grupo que recebeu dieta hiperlipídica, derivada principalmente de banha, fonte de gordura saturada, diante de um consumo semelhante de ração em quilocalorias quando comparado ao grupo que recebeu dieta normolipídica. De acordo com este estudo, um aumento do consumo energético não é obrigatório para que haja aumento da adiposidade em função de uma dieta hiperlipídica. $\mathrm{O}$ aumento de peso e tecido adiposo pode ser resultado da alteração na modulação hipotalâmica da sinalização da leptina em função da hiperleptinemia. Além disso, redução da massa e capacidade oxidativa mitocondrial também podem ser observadas em roedores alimentados com dieta hiperlipidica, favorecendo maior acúmulo de gordura (POMPLUM et al., 2007; VILLARROYA et al., 2009).

Outro fator de grande importância que também pode contribuir para maior adiposidade, independentemente de uma maior ingestão calórica, é o tipo de gordura utilizada na composição da dieta. De acordo com Buettner et al. (2006), as gorduras saturada e monoinsaturada são capazes de promover, de forma mais pronunciada, obesidade e resistência à insulina quando comparadas a gordura poliinsaturada, sendo estas capazes de gerar aumento da lipogênese e depósito de microvesículas de gordura no fígado. Esses autores afirmam ainda que, entre as gorduras utilizadas em seu trabalho, a banha de porco (mistura de gordura saturada 
e monoinsaturada) certamente é a mais recomendada para a geração de um modelo válido de roedor obeso.

Normalmente dietas ricas em gorduras são utilizadas dentro de um intervalo de $30-78 \%$ do consumo de energia total utilizado - quer por adição de uma gordura em particular à dieta do animal, quer utilizando uma variedade de alimentos de supermercados ricos em gordura e açúcar - para o estudo da obesidade em roedores (MICKELSEN et al., 1955; ELLIS et al., 2002; GHIBAUDI et al., 2002). A utilização de dietas ricas em carboidratos e pobres em gorduras não foi tão eficiente quanto a dietas indutoras de obesidade com alto teor de gordura e pobres em carboidratos (HARROLD et al., 2000; ELLIS et al., 2002; GHIBAUDI et al., 2002).

As dietas experimentais mais frequentemente utilizadas para provocar obesidade são formuladas com o acréscimo de itens lipídicos e energéticos à ração padrão. Entre esses itens estão amendoim, leite condensado, biscoitos tipo waffer ou "maizena”, óleo e chocolate (DUARTE et al., 2006; LUCAS et al., 1989).

A proposta de uma dieta experimental deve levar em consideração não só a quantidade de calorias, mas também suas características físicas e de palatabilidade. De fato, existem evidências de que as propriedades físicas da dieta podem influenciar o consumo de alimentos. Embora alimentos pastosos, com alto teor de gordura e carboidratos, e alimentos hidratados sejam bem aceitos pelos roedores (ACKROFF e SCLAFANI, 2005; DOURMASHKIN et al., 2006), deve-se levar em conta o hábito alimentar dos animais, principalmente em experimentos de longo prazo. É importante, portanto, que os roedores, sejam alimentados com pellets para que mantenham seu hábito alimentar e não passem a apresentar comportamentos indesejáveis, como o de roer partes da gaiola de manutenção. A alta palatabilidade da dieta hiperlipídica é considerada um dos fatores desencadeadores da hiperfagia dos animais tratados com esse tipo de ração (GREENBERG et al., 1999)

Diante disso, este estudo teve como propósito validar um modelo de obesidade induzida por dieta hiperlipídica, de baixo custo, fácil reprodutibilidade, que mimetizasse características observadas no humano e viabilizasse posteriores proposições terapêuticas. 
Esses dados sugerem que o maior ganho de peso e de tecido adiposo nos animais que se alimentaram da dieta hiperlipídica tenha sido em função da maior densidade energética da ração e do tipo de gordura utilizada.

Assim, de acordo com os dados obtidos de aumento do ganho de massa corpórea, observou-se o desenvolvimento de um modelo viável e reprodutível de obesidade induzida por dieta hiperlipídica em camundongos Swiss.

No trabalho de White et al. (2013), os animais sob dieta hiperlipídica obtiveram um aumento de 166,19\% de peso corpóreo, comparado à média de $138,70 \pm 19,37 \%$ nesta amostragem de nosso estudo e dentro da faixa da avaliação anterior.

No que concerne à glicemia de jejum, é bem estabelecida à relação entre o aumento de tecido adiposo ao aumento dos níveis glicêmicos após indução por dieta hiperlipídica (BUETTNER et al., 2006; FRALOUB et al., 2010).

De acordo com Polonsky et al. (1988), em um quadro de obesidade associada à resistência a insulina, inicialmente, há um aumento dos níveis desse hormônio na tentativa de manter a homeostase glicêmica. Contudo, com o tempo, haveria uma exaustão das células pancreáticas, responsáveis pela produção de insulina, e consequente queda nos níveis de insulina, intolerância a glicose e hiperglicemia, caracterizando um quadro de diabetes do tipo 2 (Shah, 1996). No presente estudo, mostrou-se que o aumento de gordura saturada na dieta também favoreceu 0 desenvolvimento da resistência a ação da insulina, intolerância a glicose e hiperglicemia, sendo esta possivelmente pela exaustão das células. Os animais obesos apresentaram valor médio de glicemia acima de $180 \mathrm{mg} / \mathrm{dL}(237,45 \pm 64,13$ $\mathrm{mg} / \mathrm{dL})$, sendo também considerados diabéticos segundo Etuk (2010).

A biodistribuição nos órgãos e tecidos nos 4 grupos de animais apresentaram alta captação nos rins refletindo uma excreção renal, seguido de pulmão, pâncreas e intestino. 
A biodistribuição em animais controle confirmaram que a captação renal foi mais robusta para o traçador GLP1- $\beta$-Ala-HYNIC- ${ }^{99 m}$ Tc do que para o ${ }^{99 m}$ Tc-HYNIC$\beta$-Ala-Exedin4 $(p<0,05)$.

A partir dos resultados obtidos no ensaio de lipofilicidade, verificou-se que o traçador ${ }^{99 \mathrm{~m}}$ Tc-HYNIC- $\beta$-Ala-Exedin4 é mais hidrofílico, porém a excreção renal é mais acentuada para o GLP1- $\beta-A l a-H Y N I C-{ }^{99 m}$ Tc. Este fato é explicado devido à meia vida biológica do GLP-1 ser mais curta por conta da rápida hidrólise pela enzima DPP-4 comparado ao Exedin4. O tempo necessário para que metade da droga absorvida, no caso o GLP-1, seja eliminada do organismo é menor comparado ao Exedin4. Portanto, o GLP-1 permanece por menor tempo no organismo e uma das principais vias da excreção é a renal, logo é possível observar uma maior captação renal para este radiotraçador.

A depuração no sangue foi rápida e semelhante para ambos os radiotraçadores. Houve uma alta captação no sangue no tempo precoce (10 minutos) com uma elevada depuração (> 80\%) depois de 1 hora, para ambos os peptídeos radiomarcados. Comparando os resultados observou-se diferença significativa de $95 \%$ entre os produtos para os tempos de 10 minutos e 1 hora, para depuração.

O sangue é composto por aproximadamente $7 \%$ de proteínas. Essas proteínas exercem a função de transportar diferentes substâncias pela corrente sanguínea, como os fármacos, e para que isso ocorra, é necessário que essas substâncias se liguem às proteínas plasmáticas. Essa ligação é reversível e não específica, e depende de vários fatores, como $\mathrm{pH}$, carga, tamanho e afinidade (RITSHEL e KEARNS, 2009).

A ligação às proteínas plasmáticas afeta diretamente a biodistribuição do radiofármaco aos tecidos de interesse. Portanto, é necessário determinar a extensão dessa ligação em qualquer fármaco novo, antes de sua utilização (SAHA, 1998).

A partir dos resultados de sangue total e ligação total ao plasma, é possível verificar que uma porcentagem mínima de radioatividade permaneceu no sangue em longo tempo para ambos radiotraçadores, representando a ligação às proteínas 
plasmáticas, e favorecendo os produtos radiomarcados que em sua maioria ficaram livres para se ligarem ao órgão de interesse.

A excreção hepatobiliar foi predominante para o traçador GLP1- $\beta$-Ala-HYNIC${ }^{99 m}$ Tc $(p<0,01)$, sendo que os sistemas hepatobiliar e renal foram considerados como principais vias de excreção para ambos os radiotraçadores.

A partir dos resultados obtidos para o estudo de biodistribuição nos 4 grupos de animais para ambos radiotraçadores, é possível observar que os animais controle evidenciaram maior captação nos órgãos de interesse, fígado e pâncreas, comparado aos demais quadros clínicos para ambos radiotraçadores.

Nos camundongos obesos há menor captação no fígado para os dois produtos radiomarcados em comparação ao grupo controle $(p<0,01)$. Animais obesos apresentam macrovesículas de gordura no fígado que causam danos às células do órgão (hepatócitos). $O$ acúmulo de gordura no fígado recebe o nome de esteatose hepática (PINTO et al., 2012).

Os animais diabéticos apresentaram menor captação no pâncreas para os traçadores GLP1-HYNIC- ${ }^{-99 m}$ Tc e ${ }^{99 m}$ Tc-HYNIC-Exedin4, devido a ação tóxica da aloxana às células beta no pâncreas, levando assim, a destruição e disjunção dessas células (ETUK, 2010; KIKUMOTO ET AL., 2010; Sharma et al., 2014. Além disso, nota-se que a captação no fígado foi inferior comparado aos animais controle, pois a indução de diabetes por aloxana gera a DM1 que também pode estar relacionada à resistência a insulina. Esta resistência é um fator de risco para o desenvolvimento de gordura no fígado e consequente dano aos hepatócitos. Observou-se uma diferença significativa $(p<0,01)$ na captação de pâncreas entre $o$ grupo controle e diabético para traçador ${ }^{99 \mathrm{~m}} \mathrm{Tc}$-HYNIC-- $\beta$-Ala-Exedin4.

O grupo de animais pós-obeso obteve considerável perda de peso, na faixa comumente observada após a cirurgia bariátrica e metabólica, substancialmente benéfica para o peso corporal e níveis de glicose no sangue. A captação no pâncreas diferiu significativamente $(p<0,05)$ com o grupo controle para ${ }^{99 m} \mathrm{Tc}$ HYNIC-- $\beta$-Ala-Exedin4. Com relação ao fígado pôde ser observada uma captação inferior comparado aos animais controle $(p<0,01)$ para ambos radiotraçadores. Isso 
pode ter ocorrido devido às células de gordura do órgão terem lesado os hepatócitos.

A técnica de coloração com hematoxilina-eosina (HE) permite diferenciar porções basófilas e acidófilas do órgão/ tecido estudado. A hematoxilina é acidófila, tendo, portanto, afinidade por substâncias ácidas, podendo corar os núcleos. A eosina é basófila, tendo afinidade pelo citoplasma, fibras colágenas e outras substâncias básicas das células (JUNQUEIRA e CARNEIRO, 2013).

Comparando-se os resultados obtidos com a literatura, pode-se verificar que os cortes histológicos dos órgãos de interesse corados com HE provenientes de camundongos sadios (grupo controle) não diferem visualmente (ROCHA, 2009; ROSELINO, 2012).

Segundo Buchanan (2003) e Seica et al. (2003), a redução na massa de células beta e a perda progressiva da função das mesmas, em indivíduos com aumento crescente da resistência à insulina, têm sido responsáveis pela indução do diabetes mellitus tipo 2.

Verifica-se que 0 animal controle, que representa um pâncreas histologicamente normal, difere visualmente do animal diabético que, certamente, teve suas células $\beta$ destruídas, confirmando os estudos realizados por Matheus e Leiter (1999) e Drews et al. (2000). 


\section{CONCLUSÃO}

- Os dois conjugados peptídicos GLP1- $\beta-A l a-H Y N I C-{ }^{99 m}$ Tc e ${ }^{99 m}$ TCHYNIC- $\beta$-Ala-Exedin4 foram marcados com tecnécio-99m, com alta pureza radioquímica.

- Ambos demonstraram serem hidrofílicos com valores de log $\mathrm{P}$ negativos.

- Uma porcentagem mínima de radioatividade permaneceu no sangue em longo tempo (2h) para ambos radiotraçadores, representando a ligação às proteínas plasmáticas, e favorecendo os produtos radiomarcados que em sua maioria ficaram livres para se ligarem ao órgão de interesse.

- O modelo experimental de indução de diabetes pela aloxana comprovou que a mesma agiu na provável destruição das células beta dos animais devido ao aumento significativo da glicemia de jejum dos camundongos induzidos (acima de 500mg/dL), caracterizando um modelo de diabetes tipo 1.

- Este estudo teve como propósito validar um modelo de obesidade induzida por dieta hiperlipídica, de baixo custo, fácil reprodutibilidade, que mimetizasse características observadas no humano e viabilizasse posteriores proposições terapêuticas. 
- A ração hiperlipídica preparada mostrou-se eficaz na indução de obesidade em camundongos Swiss

- Na biodistribuição dos traçadores observou-se acentuada excreção renal e rápida depuração sanguínea.

- Os melhores resultados para os animais controle foram observados no tempo de 1 hora após a injeção do radiotraçador, uma vez que, para ambos radiotraçadores, há evidente captação no pâncreas e fígado, além da \%Dl/mL do sangue apresentar-se em baixo nível.

- Nos camundongos obesos há menor captação no fígado para os dois produtos radiomarcados.

- Os animais diabéticos apresentaram menor captação no pâncreas para os traçadores GLP1- $\beta$-Ala-HYNIC- ${ }^{99 m}$ Tc e ${ }^{99 m}$ Tc-HYNIC- $\beta$-Ala-Exedin4.

- Com relação à análise histológica do pâncreas, fígado e tecido adiposo, foram observadas diferenças estruturais entre o grupo controle, obeso e diabético.

- Os radiotraçadores ${ }^{99 \mathrm{~m}}$ Tc-HYNIC- $\beta$-Ala-Exedin4 e GLP1- $\beta$-Ala-HYNIC${ }^{99 \mathrm{~m}} \mathrm{Tc}$ corresponderam às expectativas, evidenciando captação elevada nos órgãos de estudo (pâncreas e fígado) para o grupo controle em comparação com animais obesos e diabéticos; além das evidentes diferenças estruturais a nível histológico entre os 4 grupos de animais. Em conclusão, o traçador ${ }^{99 m}$ Tc-HYNIC- $\beta$-Ala-Exedin 4 
mostrou-se mais eficiente para detecção da massa beta funcional em obesos e diabéticos, com alta captação nos órgãos de estudo.

- Em trabalho futuro, pretende-se realizar estudos complementares a este para melhor compreensão do tema, tais como, estudos in vitro de isolamento de ilhotas pancreáticas, binding, internalização e externalização, saturação, etc. Além de estudos de seguimento longitudinal, assim como de cirurgia bariátrica e metabólica, com detalhamento celular e mapeamento molecular dos marcadores. 


\section{REFERÊNCIAS}

ABELOVE, W. A.; PASCHIKS, K. E. Comparison of the diabetogenic action of cortisone and growth hormone in different species. Endocrinol., v. 55, p. 637-640, 1954.

ABRAMS, M.J.; JUWEID, M.; TENKATE, C.I.; SCHWARTZ D.A.; HAUSER M.M.; GAUL F.E. Technetium-99m human polyclonal lgG radiolabeled via the hydrazino nicotinamide derivative for imaging focal sites of infection in rats. J. Nucl. Med., v.31, p.2022-2028, 1990.

ABREU, A. R. R. Influência da obesidade induzida por dieta hiperlipídica nas respostas cardiovasculares evocadas pelo estresse emocional em ratos. Dissertação de Mestrado, Universidade Federal de Ouro Preto, 95p., 2012.

ACKROFF, K.; LUCAS, F.; SCLAFANI, A. Flavor preference conditioning as a function of fat source. Physiol-Behav., v. 85, n. 4, p. 448-60, 2005.

AJUWON, K.M.; SPURLOCK, M.E. Palmitate activates the nf-kappab transcription factor and induces il-6 and tnfalpha expression in 3t3-l1 adipocytes. J. Nutr., v. 135, p. 1841-1846, 2005.

ALBERTO, R.; SCHIBLI, R.; EGLI, A.; SCHUBIGER, P. A.; HERMANN, W. A.; ARTUS, G.; ABRAM, V.; KADEN, T. A. Metal carbonyl syntheses XXVII. Lowpressure carbonylation of [MoCl4]- and [MO4]-. The technetium(I) and rhenium(I) complexes [Net4]2[MCI3(CO)3]. J. Org. Chem., v. 492, p. 217-224, 1995.

AMERICAN DIABETES ASSOCIATION. Diagnosis and Classification of Diabetes Mellitus. Diabetes Care, v.34, n.1, p.S62-S69, 2011.

AMORI, R.E; LAU, J; PITTAS, G.A. Efficacy and safety of incretin therapy in type 2 diabetes: Systematic Review an Meta-analysis. JAMA, v. 298, n. 2, 2007. 
AMOUYAL C, ANDREELLI F. Increasing GLP-1 circulating levels by bariatric surgery or by GLP-1 receptor agonists therapy: Why are the clinical consequences so different? J. Diabetes Res., v. 2016, p. 1-10, 2016.

ARODA, V. R; HENRY, R. R. Incretin Hormones in Diabetes and Metabolism. 2004. Disponível em: http://www.medscape.com/viewprogram/3075 acessado em 30 de julho de 2016.

AYRES, M.; AYRES, J. M.; AYRES, D. L.; SANTOS, A. S. dos. BioEstat 5.0: aplicações estatísticas nas áreas das ciências biológicas e médicas. Belém: MCT; IDSM; CNPq, 2007. 364 p. il. Acompanha CD-ROM.

BAGGIO, L. L.; DRUCKER, D. J. Biology of incretins: GLP-1 and GIP. Gastroenterol., v. 132, n. 6, p. 2131-2157, 2007.

BANDARA N, ZHELEZNYAK A, CHERUKURI K, GRIFFITH DA, LIMBERAKIS C, TESS DA, et al. Evaluation of $\mathrm{Cu}-64$ and Ga-68 radiolabeled glucagon-like peptide-1 receptor agonists as PET tracers for pancreatic $\beta$ cell imaging. Mol. Imaging Biol., v. 18, p. 90-8, 2016.

BANERJEE, S.; PILLAI, M. R. A.; RAMAMOORTHY, N. Evaluation of Tc-99m in diagnostic radiopharmaceuticals. Sem. Nucl. Med., v. 31, p. 260-277, 2001.

BANERJEE, S. R.; MARESCA, K. P.; FRANCESCONI, L.; VALLIANT, J.; BABICH, J. W.; ZUBIETA, J. New directions in the coordination chemistry of 99mTc: a reflection on technetium core structures and a strategy for new chelate design. Nucl. Med. Biol. v. 32, p. 1-20, 2005.

BAGGIO, L. L.; DRUCKER, D. J. Biology of incretins: GLP-1 and GIP. Gastroenterol., v. 132, n. 6, p. 2131-2157, 2007.

BARNETT, A. H. New treatments in type 2 diabetes: a focus on the incretin-based therapies. Clin. Endocrinol., v. 70, p. 343-353, 2009. 
BESKE, S. D. et al. Reduced cardiovagal baroreflex gain in visceral obesity: implications for the metabolic syndrome. Am. J. Physiol. Heart Circ. Physiol., v. 282, n. 2, p. H630-5, Feb 2002.

BLACKBURN, G. L. The obesity epidemic: prevention and treatment of the metabolic syndrome. Págs 1,3,4. Disponível em <http:// www.medscape.com>, About Obesity in the last 12 months, 2002.

BLOK, D.; FeITSMA, R. I. J.; VeRMEIJ, P.; PAUWELS. E. J. K. Peptide radiopharmaceuticals in nuclear medicine. Eur. J. Nucl. Med., v. 26, p. 1511-1519, 1999.

BOUSTANY, C. M. et al. AT1-receptor antagonism reverses the blood pressure elevation associated with diet-induced obesity. Am. J. Physiol. Regul. Integr. Comp. Physiol., v. 289, n. 1, p. R181-6, Jul 2005.

BOYD, R. E. Technetium-99m Generators - The Available Options. Int. J. Ap. Rad. Isot., v. 33, p. 801-809, 1982.

BUCHANAN, T. A. Pancreatic Beta-cell loss and preservation in type 2 Diabetes. Clin. Therapeutics, v. 25B, p. B32-46, 2003.

BUTLER, A. E.; JANSON, J.; BONNER-WEIR, S.; RITZEL, R.; RIZZA, R. A.; BUTLER, P. C. $\beta$-cell deficit and increased $\beta$-cell apoptosis in humans with type 2 diabetes. Diabetes, v. 52, p $102-110,2003$.

BUTLER, P. C.; MATVEYENKO, A. V. Relationship between $\beta$-cell mass and diabetes onset. Diabetes Obes. Metab.., v. 10, n. 4, p. 23-31, 2008.

BUETTNER, R.; PARHOFER, K. G.; WOENCKHAUS, M.; WREDE, C. E.; KUNZSCHUGHART, L. A.; SCHOÖLMERICH, J. et al. Defining high-fat-diet rat models: metabolic and molecular effects of different fat types. J. Mol. Endocrinol., v. 36, p. $485-501,2006$.

CALDER, P.C.; AHLUWALIA, N.; BROUNS, F.; BUETLER, T.; CLEMENT, K.; CUNNINGHAM, K.; ESPOSITO, K.; JONSSON, L.S.; KOLB, H.; LANSINK, M.; MARCOS, A.; MARGIORIS, A.; MATUSHESKI, N.; NORDMANN, H.; O'BRIEN, J.; 
PUGLIESE, G.; RIZKALLA, S.; SCHALKWIJK, C.; TUOMILEHTO, J.; WARNBERG, J.; WATZL, B.; WINKLHOFER-ROOB, B.M. Dietary factors and low-grade inflammation in relation to overweight and obesity. Br. J. Nutr., v. 106, n. 3, p. S5-78, 2011.

CARVALHO, E. N.; CARVALHO, N. A. S.; FERREIRA, L. M. Experimental modelo $f$ induction of diabetes mellitus in rats. Acta Cir. Bras., v. 18, p. 60-64, 2003.

CARROLL, J. F.; ZENEBE, W. J.; STRANGE, T. B. Cardiovascular function in a rat model of diet-induced obesity. Hypertension, v. 48, n. 1, p. 65-72, Jul 2006.

CAVELLERO, C.; MOSCA, L. Mitotic activity in the pancreatic islets of the rat under pituitary growth hormone and adrenocorticotropic hormone treatment. J. Pathol. Bacteriol., v. 66, p. 147-151, 1953.

CHACRA, A. R. Efeito fisiológico das incretinas. Adv. Stud. Med., v. 6, n. 7B, p. 613$617,2006$.

CHANG, S.; GRAHAM, B.; YAKUBU, F.; LIN, D.; PETERS, J.C.; HILL, J.O. Metabolic differences between obesityprone and obesity-resistant rats. Am. J. Physiol. Reg. Int. Comp. Physiol., v. 259, n. 6, p. 1103-10, 1990.

CNOP, M.; LANDCHILD, M. J.; VIDAL, J.; HAVEL, P. J.; KNOWLES, N. G.; CARR, D. R.; WANG, F.; HULL, R. L.; BOYKO, E. J.; RETZLAFF, B. M.; WALDEN, C. E.; KNOPP, R. H.; KAHN, S. E. The concurrent accumulation of intra-abdominal and subcutaneous fat explains the association between insulin resistance and plasma leptin concentrations: distinct metabolic effects of two fat compartments. Diabetes, v. 51, n. 4, p. 1005-1015, 2002.

CORBALAN, M. S. et al. Beta(2)-adrenergic receptor mutation and abdominal obesity risk: effect modification by gender and HDL-cholesterol. Eur. J. Nutr., v. 41, n. 3, p. 114-8, Jun 2002

DACHICOURT, N; SERRADAS, P; BAILBE, D; KERGOAT, M; DOARE, L; PORTHA, B. Glucagon-like peptide-1(7-36)-amide confers glucose sensitivity to previously 
glucoseincompetent beta-cells in diabetic rats: in vivo and in vitro studies. $\mathbf{J}$. Endocrinol., v. 155, p. 369-376, 1997.

DEACON, C. F.; NAUCK, M. A.; TOFT-NIELSEN, M.; PRIDAL, L.; WILMS, B.; HOLST, J. J. Both subcutaneously and intravenously administered glucagon-like peptide I are rapidly degraded from the $\mathrm{NH} 2$-terminus in type II diabetic patients and in healthy subjects. Diabetes, v. 44, n. 9, p. 1126-1131, 1995.

DECRISTOFORO, C.; SANTOS, I.; PIETZSCH, H.J.; KUENSTLER, J.U.; DUATTI, A.; SMITH, C.J.; REY, A.; ALBERTO, R.; VON GUGGENBERG, E.; HAUBNER, R. Comparison of in vitro and in vivo properties of [99mTc]cRGD peptides labeled using different novel Tc-cores. Q. J. Nucl. Med. Mol. Imag., v.51, p. 33-41, 2007.

DEUTSCH, E. A.; LIBSON, K.; JURISSON, S. Technetium chemistry and technetium radiopharmaceuticals, in Lippard, S. J. (ed): Progress in Inorganic Chemistry. New York, John Wiley \& Sons, Inc, p. 75-139, 1983.

DIBAISE, J.K.; ZHANG, H.; CROWELL, M.D.; KRAJMALNIK-BROWN, R.; DECKER, G.A.; RITTMANN, B.E. Gut microbiota and its possible relationship with obesity. Mayo Clin. Proc., v. 83, p. 460-469, 2008.

DINIZ, Y. S. et al. Diet compounds, glycemic index and obesity-related cardiac effects. Int. J. Cardiol., v. 124, n. 1, p. 92-9, Feb 202008.

DORNAS, W. C.; NAGEM, T. J.; OLIVEIRA, T. T. de; CONTELLI, R. Aloxano e diabetes. Revista Brasileira de Toxicologia, v. 19, n. 2, p. 81-87, 2006.

DOURMASHKIN, J.T.; CHANG, G.Q.; HILL, J.O.; GAYLES, E.C.; FRIED, S.K.; LEIBOWITZ, S.F. Model for predicting and phenotyping at normal weight the longterm propensity for obesity in Sprague-Dawley rats. Physiol Behav., v. 87, n. 4, p. 666-78, 2006.

DREWS, G.; KRAMER, C.; DUFER, M.; DREWS, P. Contrasting effect of alloxan on islets and single mouse pancreatic beta-cells. Biochem. J., v.1, n.352, p.398-397, 2000. 
DRUCKER, D. J; NAUCK, M. A. The incretin system: glucagon-like peptide-1 receptor agonists and dipeptidyl peptidase- 4 inhibitors in type 2 diabetes. Lancet, $v$. 368, 2006.

DUARTE, A. C. G. O.; FONSECA, D. F.; SOAVE, C. F.; FIORESE, M. S.; DÂMASO, A. R. Dieta hiperlipídica e capacidade secretória de insulina em ratos. Revista de Nutrição, v. 19, n. 3, p. 341 - 348, 2006.

DUNN, J. S.; SHEeHAN, H. L.; McLetCHIE, N. G. B. Necrosis os islets os Langerhans produced experimentally. Lancet, v. 1, p. 484-487, 1943.

DU TOIT, E. F.; NABBEN, M.; LOCHNER, A. A potential role for angiotensin II in obesity induced cardiac hypertrophy and ischaemic/reperfusion injury. Basic. Res. Cardiol., v. 100, n. 4, p. 346-54, Jul 2005.

EBENHAN. T.; CHADWICK, N.; SATHEKGE, M.M.; GOVENDER, P.; GOVENDER, T.; KRUGER, H.G.; MARJANOVIC-PAINTER, B.; ZEEVAART, J.R. Peptide synthesis, characterization and 68Ga-radiolabeling of NOTA-conjugated ubiquicidin fragments for prospective infection imaging with PET/CT. Nucl. Med. Biol., v.41, n.5, p.390-400, 2014.

ECKLEMAN, W. C. Sensitive of New Radiopharmaceuticals. Nucl. Med. Biol. v. 25, p. 169-173, 1998.

ELLIS, J.; LAKE, A.; HOOVER-PLOW, J. Monounsaturated canola oil reduces fat deposition in growing female rats fed a high or low fat diet. Nutr. Res., v. 22, p. 609621, 2002.

ERFANI, M.; SHAMSAEI, M.; MOHAMMADBAGHERY, F.; SHIRMARDI, S.P. Synthesis and evaluation of a $(99 \mathrm{~m})$ Tc-labeled tubulin-binding agent for tumor imaging. J. Labelled Comp. Radiopharm., v.57, n.6, p. 419-424, 2014.

ESTADELLA, D.; OYAMA, L.M.; DÂMASO, A.R.; RIBEIRO, E.B.; OLLER, C.M. Effect of palatable hyperlipidic diet on lipid metabolism of sedentary and exercised rats. Nutrition, v. 20, n. 2, p. 218-24, 2004. 
ESTADELLA, D.; OYAMA, L. M.; BUENO, A. A.; HABITANTE, C. A.; SOUZA, G. I.; RIBEIRO, E. B.; MOTOYAMA, C. S. M.; NASCIMENTO C. M. O. A palatable hyperlipidic diet causes obesity and affects brain glucose metabolismo in rats. Lipids in Health and Disease, v. 10, n. 168, p. 1-9, 2011.

ETUK, E. U. Animals models for studying diabetes mellitus. Agriculture and Biology Journal of North America, v. 1, n. 2, p. 130-134, 2010.

FAINTUCH, B. L. Estudo de marcação, biodistribuição e análise compartimental da N-acetilcisteina marcada com $99 \mathrm{mTC}$. Investigação comparativa com MIBI99mTc. 1997. Tese (Doutorado) - Instituto de Pesquisas Energéticas e Nucleares Universidade de São Paulo, São Paulo.

FAINTUCH, B.L.; SANTOS, R.L.S.R.; SOUZA, A.L.F.M.; HOFFMAN, T.J.; GREELEY, M.; SMITH, C.J.; 99mTc-HYNIC-Bombesin (7-14)NH2: Radiochemical Evaluation with Co-ligands EDDA (EDDA=Ethylenediamine-N,N'-diacetic Acid), Tricine, and Nicotinic Acid. Synth. React. Inorg. M., v.35, p 43-51, 2005.

FAINTUCH, B. L.; TEODORO, R.; OLIVEIRA, E. A. DE; NUNEZ, E. G. F.; FAINTUCH, J. Neovascularization after ischemic injury. Evaluation with ${ }^{99 m} \mathrm{Tc}$ HYNIC-RGD. Acta Cir. Bras., v. 26, n. 1, p.58-63, 2011.

FANTUZZI, G. Adipose tissue, adipokines, and inflammation. J. Allergy Clin. Immunol., v. 115, n. 5, p. 911-9; quiz 920, May 2005.

FARILLA, L.; HUI, H.; BERTOLOTTO, C.; KANG, E.; BULOTTA, A.; DI MARIO, U.; PERFETTI, R. Glucagon-like peptide-1 promotes islet cell growth and inhibits apoptosis in Zucker diabetic rats. Endocrinol., v. 143, n. 11, p. 4397-4408, 2002.

FEDERIUK, I. F.; CASEY, H. M.; QUINN, M. J.; WOOD, M. D.; WARD, W. K. Induction of type-1 diabetes mellitus in laboratory rats by use of alloxan: route od administration, pitgalls, and insulin treatment. Comp. Med., v. 3, p. 252-257, 2004.

FEHSE, F.; TRAUTMANN, M.; HOLST, J. J; HALSETH, A. E.; NANAYAKKARA, N.; NIELSEN, L. L; FINEMAN, M. S; KIM, D. D; NAUCK, M. A. Exenatide augments first- 
and second-phase insulin secretion in response to intravenous glucose in subjects with type 2 diabetes. J. Clin. Endocrinol. Metab., v. 90, n. 11, p. 5991-5997, 2005.

FENTON, P. F.; DOWLING, M. T. Studies on obesity. I. Nutritional obesity in mice. J. Nutr., v. 49, n. 2, p. 319-31, Feb 101953.

FERNANDEZ-REAL, J.M.; BROCH, M.; VENDRELL, J.; RICART, W. Insulin resistance, inflammation, and serum fatty acid composition. Diabetes Care, v. 26, p. 1362-1368, 2003.

FERREIRA, L.M.; HACHMAN, B.; BARBOSA, M.V.J. Experimental models in research. Acta Cir Bras., v. 20, n. 2, p. S28-34, 2005.

FICHNA, J.; JANECKA, A. Synthesis of target-specific radiolabeled peptides for diagnostic imaging. Bioconj. Chem., v. 14, p. 3-17, 2003.

FLINT, A.; RABEN, A.; ASTRUP, A.; HOLST, J. J. Glucagon-like peptide 1 promotes satiety and suppresses energy intake in humans. J Clin Invest, v. 101, n. 3, p. 515520. 1998.

FOX, S. I. Fisiologia Humana. 7 ed. Barueri SP: Manole, p.620 - 626, 2007.

FRALOUB, J. C.; OGG-DIAMANTINO, R.; FERNANDES-SANTOS, C.; AGUILA, M. B.; MANDARIM-DE-LACERDA, C. A. A mouse model of metebolic syndrome: insulin resistance, fatty liver and non-alcoholic fatty pancreas disease (NAFPD) in c57bl/6 mice fed a high fat diet. J. Clin. Biochem. Nutr., v. 46, n. 3, p. 1 -12, 2010.

GABBAY, M.; CESARINI, P. R.; DIB, S. A. Type 2 diabetes in children and adolescentes: literature review. Jornal de Pediatria, v. 79, n. 3, p. 201-208, 2003.

GANO, L.; PATRÍCIO, L.; MARQUES, E.; CANTINHO, G.; PENA, H.; MARTINS, T.; HNATOWICH, D. J. Human Polyclonal Immunoglobulin Labelled With Technetium99m via NHS-MAG3: A Comparison of Radiochemical Behavior and Biological Efficacy With Other Labelling Methods. Nucl. Med. Biol., v. 25, n. 4, p. 395-403, 1998. 
GARCÍA-GARAYOA, E.; MAES, V.; BLÄUENSTEIN, P.; BLANC, A.; HOHN, A.; TOURWÉ, D.; SCHUBIGER, P.A. Double-stabilized neurotensin analogues as potential radiopharmaceuticals for NTR-positive tumors. Nucl. Med. Biol., v.33, n.4, p.495-503, 2006.

GAUTIER, J. F.; CHOUKEM, S. P.; GIRARD, J. Physiology of incretins (GIP and GLP-1) and abnormalities in type 2 diabetes. Diabet. Metab., v. 34, n. 2, p. S65-S72, 2008.

GALLWITZ, B. The evolving place of incretin-based therapies in type 2 diabetes. Pediatr. Nephrol., v. 25, p. 1207-1217, 2010.

GERICH, J. DPP-4 inhibitors: What may be the clinical differentiators? Diabetes Res. Clin. Pract., v. 90, p. 131-140, 2010.

GHIBAUDI, L. et al. Fat intake affects adiposity, comorbidity factors, and energy metabolism of sprague-dawley rats. Obes Res, v. 10, n. 9, p. 956-63, Sep 2002.

GIORGINO, F.; LAVIOLA, L.; LEONARDINI, A.; NATALICCHIO, A. GLP-1: a new approach for type 2 diabetes therapy. Diabetes Res. Clin. Pract., v. 74, p. S152S155, 2006.

GUO, Z.; ZHANG, P.; SONG, M.; WU, X.; LIU, C.; ZHAO, Z.; LU, J.; ZHANG, X. Synthesis and preliminary evaluation of novel $99 \mathrm{mTc}$-labeled folate derivative via click reaction for SPECT imaging. Appl. Radiat. Isot., v.14, n. 91C, p. 24-30, 2014.

GUVEN, S.; KUENZI J. A.; MATFIN, G.; Diabetes Mellitus. In: PORTH, C. M.; KUNERT, M. P. Fisiopatologia. Rio de Janeiro RJ: Guanabara Koogan S.A, 2004. p.897- 921 .

GREEN, B; FLATT, P; BAILEY, C. Dipeptidyl peptidase IV (DPP IV) inhibitors: a newly emerging drug class for the treatment of type 2 diabetes. Diabetes Vasc. Dis. Res., v. 3, p. 159, 2006.

GREEN, C. H. Technetium-99m production issues in the United Kingdom. J. Med. Phys., v. 37, n. 2, p. 66-71, 2012. 
GREENBERG, D.; MCCAFFERY, J.; POTACK, J.Z..; BRAY, G.A.; YORK, D.A. Differential satiating effects of fats in the small intestine of obesity-resistant and obesity-prone rats. Physiol Behav., v. 66, n. 4, p. 621-26, 1999.

GROSS, J. L.; SILVEIRO, S. P.; CAMARGO, J. L.; REICHELT, A. J. AZEVEDO, M. J. Diabetes Melito: Diagnostico, Classificação e Avaliação do Controle Glicêmico. Arquivos Brasileiros de Endocrinologia \& Metabologia, v. 46, n. 1, 2002.

GRossi, S. A. A.; LOTTENBERG, S. A.; LOTTENBERG, A. M. P.; DELLE MANNA, T.; KUPERMAN, H. Hipoglicemia em pacientes com Diabetes Mellitus do tipo 1. Revista Gaúcha de Enfermagem, v.28, n.3, p.368-376, 2007.

HAMOUDEH, M.; KAMLEH, M. A.; DIAB, R.; FESSI, H. Radionuclides delivery systems for nuclear imaging and radiotherapy of cancer. Adv. Drug. Deliv. Rev, v. 60, n. 12, p. 1329-1346, 2008.

HANSEL, D. E.; DINTZIS, R. Z. Fundamento de Patologia. 1 ed. Rio de Janeiro: Guanabara Koogan S.A, 2007. p.685- 686.

HARRIS, R.B.S. Factors influencing energy intake of rats fed either a high-fat or a fat mimetic diet. Int. J. Obes., v. 18, n. 9, p. 632-40, 1994.

HARROLD, J. A.; WILLIAMS, G.; WIDDOWSON, P. S. Early leptin response to a palatable diet predicts dietary obesity in rats: key role of melanocortin-4 receptors in the ventromedial hypothalamic nucleus. J. Neurochem., v. 74, n. 3, p. 1224-8, Mar 2000.

HAUSBERGER, F. X.; RAMSAY, A. J.; Islet hypertrophy in obesity of mice bearing ACTH-secreting tumors. Endocrinology, v. 65, p. 165-169, 1959.

HENRY, J. B. Diagnósticos Clínicos e tratamento por métodos laboratoriais. 20 ed. Barueri SP: Manole, 2008. p.245-254.

HNATOWICH, D.J.; MARDIRIOSSIAN, G.; RUSCOWSKI, M.; FORGARASI, M.; VIRZI, F.; WINNARD, P. Directly and indirectly technetium-99m labeled antibodies: A comparison of in vitro and animal in vivo properties. J. Nucl. Med., v.34, p.109-119, 1993. 
HNATOWICH, D.J.; WINNARD, P.; VIRZI, F.; FORGARASI, M.; SANO, T.; SMITH, C.L.; RUSCOWISKI, M. Technetium-99m labeling of DNA oligonucleotides. J. Nucl. Med., v.36, p.2306-2314, 1995.

HOLST, J. J.; GROMADA, J. Role of incretin hormones in the regulation of insulin secretion in diabetic and nondiabetic humans. Am. J. Physiol. Endocrinol. Metab., v. 287, p. E199- E206, 2004.

INGLE, D. J. A simple means of producing obesity in the rat. Proc Soc Exp Biol Med, v. 72, n. 3, p. 604, Dec 1949.

ISLAM, S. (ed). The islets of Langerhans. Advances in experimental medicine and biology. Heidelberg, Alemanha: Springer, v. 654, 800p., 2010.

JANSSEN, M.L.; OYEN, W.J.; DIJKGRAAF, I.; MASSUGER, L.F.; FRIELINK, C.; EDWARDS, D.S.; RAJOPADHYE, M.; BOONSTRA, H.; CORSTENS, F.H.; BOERMAN, O.C. Tumor targeting with radiolabeled alpha(v)beta(3) integrin binding peptides in a nude mouse model. Cancer Res., v.62, p. 6146-6151, 2002.

JODAL, A.; LANKAT-BUTTGEREIT, B.; BROM, M.; SCHIBLI, R.; BÉHÉ, M. A comparison of three $67 / 68 \mathrm{Ga}$-labelled exedin-4 derivatives for $\beta$-cell imaging on the GLP-1 receptor: the influence of the conjugation site of NODAGA as chelator. Eur. J. Nucl. Med. Mol. Imag., v. 4, n. 31, p. 1-10, 2014.

JUNQUEIRA, L. C.; CARNEIRO, J. Histologia básica. Rio de Janeiro: Guanabara Koogan, 12ª ed., 556p., 2013.

JURISSON, S. S.; LYDON, J. D.; Potencial Techenetium small molecule radiopharmaceutical. Chem. Rev., v. 99, p. 2205-2218, 1999.

JURISSON, S. S. Tc and Re peptide chemistry: direct labeling. In NICOLINI, M.; MAZZI, U. (Ed.). Technetium, rhenium and other methals in chemistry and nuclear medicine. Padova, Italy: SGEditoriali, v. 6, p. 15-21, 2002.

KAUFMAN, L. N.; PETERSON, M. M.; SMITH, S. M. Hypertension and sympathetic hyperactivity induced in rats by high-fat or glucose diets. Am. J. Physiol., v. 260, n. 1 Pt 1, p. E95-100, Jan 1991. 
KASINA, S.; SANDERSON, J.A.; FITZNER, J.N.; SRINIVASAN, A.; RAO, T.N.; HOBSON, L.J.; RENO, J.N.; AXWORTHY, D.B.; BEAUMIER, P.L.; FRITZBERG, A.R. Simplified preformed chelate protein radiolabeling with technetium-99m mercaptoacetamidoadipoylglycylglycine (N3S-adipate). Bioconjug. Chem., v. 9, p. 108-117, 1998.

KENNEDY, A.; MARTINEZ, K.; CHUANG, C.C.; LAPOINT, K.; MCINTOSH, M. Saturated fatty acid-mediated inflammation and insulin resistance in adipose tissue: Mechanisms of action and implications. J. Nutr., v. 139, p. 1-4, 2009.

KERN, H.; LOGOTHETOPOULOS, J. Steroid diabetes in the guinea pig: studies on islet cell ultrastructure and regeneration. Diabetes, v. 19, p. 145-151, 1970.

KHARISOV, B. I. and MENDES-ROJAS, M. A. State-of-the-art coordination chemistry of radioactive elements. Russian Chem. Rev., v. 70, p. 865-874, 2001.

KIKUMOTO, Y.; SUGIYAMA, H.; INOUE, T.; MORINAGA, H.; TAKIUE, K.; KITAGAWA, M.; FUKUOKA, N.; SAEKI, M.; MAESHIMA, Y.; WANG, D.H.; OGINO, K.; MASUOKA, N.; MAKINO, H. Sensitization to alloxan-induced diabetes and pancreatic cell apoptosis in acatalasemic mice. Biochim. Biophys. Acta, v. 1802, p. 240-246, 2010.

KOPECKY, M., SEMECKY, V., TREJTNAR, F., LAZNICEK, M., LAZNICKOVA, A., NACHTIGAL, P., DECRISTOFORO, C., MATHER, S. J., MÄCKE, H.R. Analysis of accumulation fo $99 \mathrm{mTc}$-octreotide and 99mTc-EDDA-HYNIC-Tyr3-octreotide in the rat kidneys. Nucl. Med. Biol., v.31, p. 231-239, 2004.

KOTHARI, K.K.; RAGHURAMAN, K., PILLARSETTY, N.K.; HOFFMAN, T.J.; OWEN, N.K.; KATTI, K.V.; VOLKERT, W.A. Syntheses, in vitro and in vivo characterization of a $99 \mathrm{mTc}$-(I)-tricarbonyl-benzylamino-dihydroxymethyl phosphine (NP2) chelate. Appl. Radiat. Isot,, v.58, p.543-549, 2003.

KOWALSKY, R.J.; FALEN, S.W. Radiopharmaceuticals in Nuclear Pharmacy and Nuclear Medicine. 2. ed. American Pharmacists Association, Washington DC, 2004. 
LAURENT D, VINET L, LAMPRIANOU S, DAVAL M, FILHOULAUD G, KTORZA A, et al. Pancreatic $\beta$-cell imaging in humans: fiction or option? Diabetes Obes. Metab., v. 18, p. $6-15,2016$.

LEHTONEN J, SCHÄFFER L, RASCH MG, HECKSHER-SØRENSEN J, AHNFELTRØNNE J. Beta cell specific probing with fluorescent exendin-4 is progressively reduced in type 2 diabetic mouse models. Islets, v.7, p. e1137415-1- e1137415-10, 2015.

LEME, J. A. C. A.; CASTELLAR, A.; REMEDIO, R. N.; BARBOSA, R. A.; MOURA, L. P.; DALIA, R. A.; GOMES, R. J.; CAETANO, F. H.; MELLO, M. A. R.; LUCIANO, E. Efeitos em curto prazo da aplicação de aloxana para indução de diabetes em ratos Wistar. Bioscience J., v. 26, n. 3, p. 451-456, 2010.

LENZEN, D. The mechanisms of alloxan and streptozotocin induced diabetes. Diabetologia, v. 51, p. 216-226, 2008.

LERCO, M. M.; SPADELLA, C. T.; MACHADO, J. L. M.; SCHELLINI, S. A.; PADOVANI, C. R. Caracterização de um modelo experimental de Diabetes Mellitus, induzido pela aloxana em ratos. Estudo clínico e laboratorial. Acta Cir. Bras., v. 18, n. 2 , p. $132-142,2003$

LIEN, L.F.; GUYTON, J.R. Metabolic syndrome. Dermatol. Ther., v. 21, p. 362-375, 2008.

LIKE, A. A.; CHICK, W. L. Pancreatic betta cell replication induced by glucocorticoids in subhuman primates. Amer. J. Pathol., v. 75, p. 329-332, 1974.

LIMA, M. A.; LIMA, L. M. B.; RITA, D. P. C.; NAVARRO, F. C.; TATSUKAWA, R. S.; PEREIRA, G. A.; REIS, L. C.; ABREU, M. E. A.; BORGES, M. F. Análise quantitativa das células das ilhotas pancreáticas em ratos sob efeito de aloxana. Medicina, v. 34, p. 308-314, 2001.

LIU, S.; EDWARDS, D. S. 99mTc-labeled small peptides as diagnostic radiopharmaceuticals. Chem. Rev., v. 99, p. 2235-2268, 1999. 
LIU, S.; ROBINSON, S.P.; EDWARD, D.S. Integrin avb3 directed radiopharmaceuticals for tumor imaging. Drugs of the Future, v.28, n.6, p. 551-564, 2003.

LIU, S. The role of coordination chemistry in the development of target-specific radiopharmaceuticals. Chem. Soc. Rev., v. 33, p.445-461, 2004.

LIU, S. Bifunctional coupling agents for radiolabeling of biomolecules and targetspecific delivery of metallic radionuclides. Adv. Drug Deliv. Rev., v. 60, p. 1347-1360, 2008.

LUCAS, F.; ACKROFF ,K.; SCLAFANI, A. Dietary fat-induced hyperphagia in rats as a function of fat type and physical form. Physiol-Behav., v. 45, n. 5, p. 937-46, 1989.

MANN RJ, NASR NE, SINFIELD JK, PACI E, DONNELLY D. The major determinant of exendin-4/glucagon-like peptide 1 differential affinity at the rat glucagon-like peptide 1 receptor N-terminal domain is a hydrogen bond from SER-32 of exendin-4. Br. J. Pharmacol., v. 160, p. 1973-84, 2010.

MACHADO, U. F.; SCHAAN, B. D.; SERAPHIM, P. M. Transportadores de Glicose na Síndrome Metabólica. Arquivos Brasileiros de Endocrinologia \& Metabologia, v. 50, n.2, 2006.

MACHADO, J. L. M.; ORTOLANI, E. V. P.; SPADELLA, C. T. Anastomotic healing in ileum and colono f alloxan-induced diabetic rats. Acta Cirúrgica Brasileira, v. 24, n, $1,2009$.

MAINA, T.; NIKOLOPOULOU, A.; STATHOPOULOU, E.; GALANIS, A.S.; CORDOPATIS, P.; NOCK, B.A. [99mTc]Demotensin 5 and 6 in the NTS1-R-targeted imaging of tumours: synthesis and preclinical results. Eur. J. Nucl. Med. Mol. Imaging, v.34, n.11, p.1804-1814, 2007.

MARRIF HI, AL-SUNOUSI SI. Pancreatic $\beta$ cell mass death. Front. Pharmacol., v. 7, p. 1-16, 2016. 
MARTINEZ, J. A.; FRUHBECK, G. Regulation of energy balance and adiposity: a model with new approaches. Rev. Esp. Fisiol., v. 52, n. 4, p. 255-8, Dec 1996.

MARQUES-LOPES, I. et al. Postprandial de novo lipogenesis and metabolic changes induced by a high-carbohydrate, low-fat meal in lean and overweight men. Am. J. Clin. Nutr., v. 73, p. 253-61, 2001.

MARQUES, F. L. N.; OKAMOTO, M. R. Y.; BUCHPIGUEL, C. A. Alguns aspectos sobre geradores e radiofármacos de tecnécio-99m e seus controles de qualidade. Radiologia Brasileira, v. 24, n. 4, p.233-239, 2001.

MATHEUS, C.E.; LEITER, E.H. Constitutive differences in antioxidant defense status distinguish alloxan-resistant and alloxan-susceptible mice. Free Rad. Biol. Med., v.27, n.3, p.449-455, 1999.

MCINTYRE, N. HOLDSWORTH, C. D.; TURNER, D. S. Intestinal factors in the control of insulin secretion. J. Clin. Endocrinol. Metab., v. 25, n. 10, p. 1317-1324, 1965.

MCLELLAN, K. C. P.; BARBALHO, S. M.; CATTALINI, M.; LERARIO, A. C. Diabetes mellitus do tipo 2, síndrome metabólica e modificação no estilo de vida. Braz. J. Nutr., v.20, n.5, p. 515-524, 2007.

MENDONÇA, C.P.; DOS ANJOS, L.A. Dietary and physical activity factors as determinants of the increase in overweight/obesity in brazil]. Cad. Saude Publica, v. 20 , p. $698-709,2004$

MEIER JJ, BONADONNA RC. Role of reduced $\beta$-cell mass versus impaired $\beta$-cell function in the pathogenesis of type 2 Diabetes. Diabetes Care, v. 36, p. S113S119, 2013.

MESZAROS, L.K.; DOSE, A.; BIAGINI, S.C.G.; BLOWER, P.J. Hydrazinonicotinic acid (HYNIC) - Coordination chemistry and applications in radiopharmaceutical chemistry. Inorg. Chim. Acta., v. 363, p. 1059-1069, 2010. 
MICKELSEN, O.; TAKAHASHI, S.; CRAIG, C. Experimental obesity. I. Production of obesity in rats by feeding high-fat diets. J. Nutr., v. 57, n. 4, p. 541-54, Dec 101955.

MI B, XU Y, PAN D, WANG L, YANG R, YU C, et al. Non-invasive glucagon-like peptide-1 receptor imaging in pancreas with (18)F-Al labeled Cys(39)-exendin-4. Biochem. Biophys. Res. Commun., v.471, p. 47-51, 2016.

MOURA, L. P. de; GOMES, R. J.; LEME, J. A.; VOLTARELLI, F. A.; RIBEIRO, C.; MOURA, R. F. de; ARAÚJO, M. B. de; LUCIANO, E.; MELLO, M. R. de. Insulina pancreática de ratos diabéticos tipo 1 submetidos a um protocolo de treinamento físico individualizado. Motricidade, v. 8, n. 1, p. 23 - 32, 2012.

NASCIMENTO, A. F.; SUGIZAKI, M. M.; LEOPOLDO, A. S.; LIMA-LEOPOLDO, A.P.; NOGUeIRA, C. R.; NOVELLI, A. L. B.; PADOVANI, C. R.; CICOGNA, A. C. Misclassification probability as obese or lean in hypercaloric and normocaloric diet. Biol. Res., v. 41, p. 253-259, 2008.

OKARVI, S. M. Synthesis, radiolabeling and in vitro and in vivo characterization of a technetium-99m-labeled alpha-M2 peptide as a tumor imaging agent. J. Peptide Res., v.63, p.460-468, 2004.

OLIVEIRA, É.A.; FAINTUCH, B.L.; NÚÑEZ, E.G.; MORO, A.M.; NANDA, P.K.; SMITH, C.J. Radiotracers for different angiogenesis receptors in a melanoma model. Melanoma Res., v.22, n.1, p.45-53, 2012.

PEREIRA, S.S.; TEIXEIRA, L.G.; AGUILAR, E.C.; MATOSO, R.O.; SOARES, F.L.; FERREIRA, A.V.; ALVAREZ-LEITE, J.I. Differences in adipose tissue inflammation and oxidative status in c57bl/6 and apoe-/- mice fed high fat diet. Anim. Sci. J., v. 83, p. 549-555, 2012.

PERES, L. C.; RIBEIRO, C. N. de M.; GUTIERREZ, C. M.; FOSS, M. C. Effect of alloxan-induced diabetes mellitus and etanol on pregnancy outcome in mice. Jornal Brasileiro de Patologia e Medicina Laboratorial, v. 45, n. 6, p. 471-480, 2009.

PINTO, C. G. S.; MAREGA, M.; CARMONA, F. G.; D’ÁUREA, C.; CARVALHO, J. A. M.; FIGUEIRA Jr, A. Esteatose Hepática e Estilo de Vida Ativo: Revisão de 
Literatura. Revista Brasileira de Ciência e Movimento, v. 20, n. 3, p. 125 - 134, 2012.

PLACHCINSKA, A.; MIKOLAJCZAK, R.; MAECKE, H.; KOZAK, J.; MICHALSKI, A.; RZESZUTEK, K.; KUSMIEREK, J. Efficacy of 99mTc-EDDA/HYNIC-TOC scintigraphy in differential diagnosis of solitary pulmonary nodules. Cancer Biother. Radiopharm., v.19, n.5, p. 613-620, 2004.

POLONSKY, K. S.; GIVEN, B. D.; HIRSCH, L.; SHAPIRO, E. T.; TILLIL, H.; BEEBE, C. et al. Quantitative study of insulin secretion and clearance in normal and obese subjects. Eur. J. Clin. Investig., v. 81, p. 435 - 441, 1988.

POMPLUN, D.; VOIGT, A.; SCHULZ, T.J.; THIERBACH, R.; PFEIFFER, A.F.; RISTOW, M. Reduced expression of mitochondrial frataxin in mice exacerbates dietinduced obesity. PNAS, v. 104, n. 15, p. 6377-81, 2007.

PREITNER, F.; IBBERSON, M.; FRANKLIN, I.; BINNERT, C.; PENDE, M.; GJINOVCI, A. et al. Gluco-incretins control insulin secretion at multiple levels as revealed in mice lacking GLP-1 and GIP receptors. J. Clin. Invest., v. 113, n. 4, p. 635-645, 2004.

PRICE, E.W.; ORVIG, C. Matching chelators to radiometals for radiopharmaceuticals. Chem. Soc. Rev., v.43, n.1, p.260-290, 2014.

PRIOR, R.L.; WU, X.; GU, L.; HAGER, T.J.; HAGER, A.; HOWARD, L.R. Whole Berries versus Berry Anthocyanins: interactions with dietary fat levels in the C57BL/6J mouse model of obesity. J Agric Food Chem., v. 56, p. 647-53, 2008.

RASOULI, N.; KERN, P.A. Adipocytokines and the metabolic complications of obesity. J. Clin. Endocrinol. Metab., v. 93, p. S64-73, 2008.

RAYNER, C. K; SAMSOM, M.; JONES, K. L; HOROWITZ, M. Relationships of upper gastrointestinal motor and sensory function with glycemic control. Diabetes Care, v. 24, n. 2, 2001.

RICE, M.C.; O'BRIEN, S.J. Genetic variance of laboratory outbred Swiss mice. Nature, v. 283, p. 157-61, 1980. 
RITSCHEL, W.A; KEARNS, G.L. Definitions and nomenclature. In: (Ed.). Handbook of basic pharmacokinectis including clinical applications. Washington American Pharmacists Association, 2009. Cap.1, p.1-11.

ROCHA, D. A. Tese de doutorado pela Universidade Federal de Lavras - UFLA. Avaliação do efeito hipoglicemiante e hipocolesterolêmico do polvilho da frutade-lobo (Solanum lycocarpum St. Hil). 90p., 2009.

ROSELINO, M. N. Dissertação de mestrado pela Faculdade de Ciências Farmacêuticas da Universidade Estadual Paulista Júlio de Mesquita Filho - UNESP. Avaliação do simbiótico fermentado com Enterococcus faecium CRL 183 e Lactobacillus helveticus ssp jugurti 416, à base de extratos aquosos de soja e de yacon (Smallanthus sonchifolius) no controle do desenvolvimento do Diabetes Mellitus. 98p., 2012.

RUNGE S, SCHIMMER S, OSCHMANN J, SCHIØDT CB, KNUDSEN SM, JEPPESEN CB, et al. Differential structural properties of GLP-1 and exendin-4 determine their relative affinity for the GLP-1 receptor N-terminal extracellular domain. Biochem., v. 46, p. 5830-40, 2007.

RUSSELL-JONES, D.; GOUGH, S. Recent advances in incretin-based therapies. Clin. Endocrinol. Accepted Articles, 2012.

SAHA, G. B. Fundamentals of Nuclear Pharmacy. 6a edition. New York: Springer, 2010.

SALEHI M, GASTALDELLI A, D'ALESSIO DA. Altered islet function and insulin clearance cause hyperinsulinemia in gastric bypass patients with symptoms of postprandial hypoglycemia. J. Clin. Endocrinol. Metab., v. 99, p.2008-17, 2014.

SCHWARTZ, J. G; GREEN, G. M; GUAN, D.; MCMAHAN, C, A.; PHILLPS, W. T. Rapid gastric emptying of a solid pancake meal in type II diabetic patients. Diabetes Care, v.19, n. 5, 1996.

SCHOSSLER, D. R. C.; MAZZANTI, C. M.; LUZ, S. C. A.; FILAPPI, A.; PRESTES, D.; SILVEIRA, A. F.; CECIM, M. Alterações histológicas e imunoistoquímicas em 
pâncreas de ratos normais e diabéticos tratados com Syzygium cumini. Ciência Rural, v. 34, n. 6, p. 1821-1825, 2004.

SCLAFANI, A.; SPRINGER, D. Dietary obesity in adult rats: similarities to hypothalamic and human obesity syndromes. Physiol. Behav., v. 17, n. 3, p. 461-71, Sep 1976.

SHAH, P. Insulin resistance (IR) in impaired glucose tolerance (IGT). International Journal of Diabetes in Developing Countries, v. 16, p. 16 - 18, 1996.

SHARMA, B.; SIDDIQUI, M. S.; RAM, G.; YADAV, R. K.; KUMARI, A.; SHARMA, G.; JASUJA, N. D. Rejuvenating of kidney tissues on alloxan induced diabetic mice under the effect of Momordice charantia. Advances in Pharmaceutics, v. 1, p. 1-9, 2014.

SEICA, R. M.; MARTINS, M. J.; PESSA, P. B.; SANTOS, R. M.; ROSARIO, L. I.; SUZUki, K. I. et al. Morphogical changes of islet of Langerhans in an animal model of type 2 diabetes. Acta Médica Portuguesa, v. 16, n. 6, p. 381 - 388, 2003.

SILVA, F. R. M. B.; SZPOGANICZ, B. PIZZOLATTI, M. G. WILLRICH, M. A. V.; SOUSA, E. Acute effect of Bauhinia foficata on serum glucose levels in normal and alloxan-induced diabetic rats. Journal of Ethnopharmacology, v. 83, p. 33-37, 2002.

SILVA, K. E. da; GOMES, R. J.; HERMINI, H. A.; AZEVEDO, J. R. M de; CARNEIRO, E. M.; LUCIANO, E. Perfil metabólico de ratos diabéticos submetidos ao exercício físico. Matriz, v. 10, n. 3, p. 189 - 193, 2004.

SILVEIRA, L. A. G. Correlação entre obesidade e diabetes tipo 2. Revista Digital Vida e Saúde, v. 2, n. 2, p. 1 - 7, 2003.

SISTA F, ABRUZZESE V, CLEMENTI M, CARANDINA S, AMICUCCI G. Effect of resected gastric volume on ghrelin and GLP-1 plasma levels: a prospective study. J. Gastrointest. Surg., v. 20, p. 1931-41, 2016. 
SKELIN, M.; RUPNIK, M.; CENCIC, A. Pancreatic beta cell lines and their applicatios in diabetes mellitus research. Altex Journal, v. 27, n. 2/10, p. 105 - 113, 2010.

SOARES, J. C. M.; COSTA, S. T. da; CECIM, M. Níveis glicêmicos e de colesterol em ratos com Diabetes mellitus aloxano induzido, tratados com infusão de Bauhinia candicans ou Syzygium jambolanum. Ciência Rural, v. 30, n. 1; p. 113 - 118, 2000.

SOCIEDADE BRASILEIRA DE DIABETES. Novos lançamentos, novas tecnologias: Inibidores da DPPIV, v. 14, n. 3, 2007.

SU, Z.F.; HE, J.; RUSCKOWSKI, M.; HNATOWICH, D.J. In vitro cell studies of technetium-99m labeled RGD-HYNIC peptide, a comparison of tricine and EDDA as co-ligands. Nucl. Med. Biol., v.30, p.141-149, 2003.

SZKUDELSKI, T. The mechanism of alloxan and streptozotocin action in B cells of the rat pancreas. Phys. Res., n. 50, p. 536-546, 2001.

TAMBASCIA, M. A; NETO, B. G.; EliASCHEWITZ, F. G.; GROSS, J. L. Novas perspectivas para o tratamento do diabetes tipo 2: incretinomiméticos e inibidores da DPP-IV. Revista Brasileira de Medicina, 2007.

TAMURA K, MINAMI K, KUDO M, IEMOTO K, TAKAHASHI H, SEINO S. Liraglutide improves pancreatic beta cell mass and function in alloxan-induced diabetic mice. PLoS One, v. 10: p. 1-15, 2015.

TEIXEIRA, L. G. Interação entre obesidade induzida por dieta hiperlipídica e colite crônica aumenta reciprocamente a inflamação no tecido adiposo e no cólon. Tese de Doutorado, Universidade Federal de Minas Gerais, 152p., 2012.

TSCHOP, M.; HEIMAN, M.L. Rodent obesity models: an overview. Exp. Clin. Endocrinol. Diabetes, v. 109, n. 6, p. 307-19, 2001.

TOWNSEND, K.L.; LORENZI, M.M.; WIDMAIER, E.P. High-fat diet-induced changes in body mass and hypothalamic gene expression in wild-type and leptin-deficient mice. Endocrine., v. 33, n. 2, p. 176-88, 2008. 
VAN DER LAKEN, C.J.; BOERMAN, O.C.; OYEN, W.J.G.; VAN DER VEM, M.T.P.; EDWARDS, D.S.; BARRETT, J.A.; VAN DER MEER, J.W.M.; CORSTENS, F.H.M. Technetium-99m-labeled chemotactic peptides in acute infection and sterile inflammation. J. Nucl. Med., v.38, p.1310-1315, 1997.

VANLIC-RAZUMENIC, N.; PETROVIC, J.; GORKIC, D. Biochemical studies of the renal radiopharmaceutical compound dimercaptosuccinate. IV. Interaction of 99mTcDMS and 99Tc-DMS complexes with blood serum proteins. Eur. J. Nucl. Med. Mol. Imag., v. 9, n. 8, p.370 - 373, 1984.

VILLARROYA, J.; GIRALT, M.; VILLARROYA, F. Mitochondrial DNA: An up-andcoming actor in white adipose tissue pathophysiology. Obesity, v. 17, n. 10, p. 181420, 2009.

VILSBOLL, T.; GARBER, A. J. Non-glycaemic effects mediated via GLP-1 receptor agonists and the potential for exploiting these for therapeutic benefit: focus on liraglutide. Diab. Obes. Metabol., v. 14, suppl. 2, p. 41-49, 2012.

WEATHERILL, A.R.; LEE, J.Y.; ZHAO, L.; LEMAY ,D.G.; YOUN, H.S.; HWANG, D.H. Saturated and polyunsaturated fatty acids reciprocally modulate dendritic cell functions mediated through tIr4. J. Immunol., v. 174, p. 5390-5397, 2005.

WEEKS, M. E. The discovery of the elements. XX. Recently discovered elements. J. Chem. Education, v.10, n.3, p.161-170, 1993.

WEINER R.E.; THAKUR M.L. Radiolabeled Peptides in Oncology: role in diagnosis and treatment. Biodrugs., v.19, n.3, p.145-163, 2005.

WELCH, M. J.; REDVANLY, C. S. Handbook of Radiopharmaceuticauls Radiochemistry and Applications. England: Wiley, 2003.

WEST, D.B.; BOOZER, C.N.; MOODY, D.L.; Atkinson, R.L. Dietary obesity in nine inbred mouse strains. AJP - Regu Phyisiol., v. 262, p. R1025-32, 1992.

WEST, D.B.; YORK, B. Dietary fat, genetic predisposition, and obesity: lessons from animal models. Am J Clin Nutr., v. 67, n. 3, p. S505-12, 1998. 
White, P. A. S.; CeRCATO, L. M.; ARAÚJO, J. M. D.; SOUZA, L. A.; SOARES, A. F.; BARBOSA, A. P. O.; NETO, J. M. DE R.; MARÇAL, A. C.; MACHADO, U. F.; CAMARGO, E.; SANTOS, M. R. V.; BRITO, L. C. Modelo de obesidade induzida por dieta hiperlipídica e associada à resistência à ação da insulina e intolerância à glicose. Arquivos Brasileiros de Endocrinologia \& Metabologia, v. 57, n. 5, p. $339-345,2013$.

WILD, S.; ROGLIC, G.; GREEN, A.; SICREE, R.; KING, H. Global prevalence of diabetes: estimates for the year 2000 and projections for 2030. Diabetes Care, New York, v. 27, p. 1047-1053, 2004.

WINZELL, M.S.; AHRÉN, B. The high-fat diet-fed mouse a model for studying mechanisms and treatment of impaired glucose tolerance and type 2 diabetes. Diabetes, v. 53, n. 3, p. S215-9, 2004.

WOODS, S. C. et al. A controlled high-fat diet induces an obese syndrome in rats. J. Nutr., v. 133, n. 4, p. 1081-7, Apr 2003.

WOODS, S.C.; SEELEY, R.J.; RUSHING, P.A.; DÁLESSIO, D.; TSO, P. A controlled high-fat diet induces an obese syndrome in rats. J. Nutr., v. 133, n. 5, p. 1081-7, 2003.

WORLD HEALTH ORGANIZATION. Definition, diagnosis and classification of diabetes mellitus and its complications: report of a WHO consultation. Geneva, World Health Organization, 1999.

WORLD HEALTH ORGANIZATION. Overweight and Obesity 2011.

WU Z, LIU S, NAIR I, OMORI K, SCOTT S, TODOROV I, et al. ${ }^{64} \mathrm{Cu}$ Labeled sarcophagine exendin-4 for microPET imaging of glucagon like peptide-1 receptor expression. Theranostics, v. 4, p. 770-7, 2014.

XU, G.; KANETO, H.; LAYBUTT, D. R. Downregulation of GLP-1 and GIP receptor expression. By hyperglucemia: possible contribution to impaired incretin effects in diabetes. Diabetes, v. 56, n. 6, p. 1551-1558, 2007. 
ZHANG, Y.M.; LIU, N.; ZHU, Z.H.; RUSCKOWSKI, M.; HNATOWITCH, D.J. Influence of different chelators (HYNIC, MAG3 and DTPA) on tumor cell accumulation and mouse biodistribution of technetium-99m labeled to antisense DNA. Eur. J. Nucl. Med., v.27, n. 11, p. 1700-1707, 2000.

ZHOU, Y.; CHAKRABORTY, S.; LIU, S. Radiolabeled Cyclic RGD Peptides as Radiotracers for Imaging Tumors and Thrombosis by SPECT. Theranostics, v.1, p.58-82, 2011.

ZOLLE, I. Technetium-99m pharmaceuticals: preparation and quality control in Nuclear Medicina. New York: Springer Berlin Heidelberg, 2007. 
ANEXO 1 


\section{ANEXO 1 - APROVAÇÃO DO COMITÊ DE ÉTICA DO IPEN}

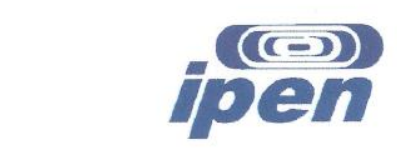

Comissão de Ética no Uso de Animais

Parecer - Projeto N 147/14/CEUA-IPEN/SP

Com base nos pareceres apresentados pelos relatores, o protocolo de pesquisa "DESENVOLVIMENTO DE BIOMARCADOR ESPECÍFICO DE CÉLULAS BETA PANCREÁtICAS (INCRETINA RADIOMARCADA) PARA IMAGEM DE MASSA BETA FUNCIONAL EM DIABÉTICOS E OBESOS: ESTUDO EM MODELO ANIMAL" de responsabilidade da pesquisadora DRa BLUMA L. FAINTUCH foi considerado APROVADO.

Tendo em vista a legislação vigente, devem ser encaminhados, a este Comitê, relatórios anuais (parciais ou finais, dependendo da duração do projeto) referentes ao andamento da pesquisa. Após o término da pesquisa, uma cópia do trabalho deve ser encaminhada a este CEUA.

São Paulo, 08 de dezembro de 2014.

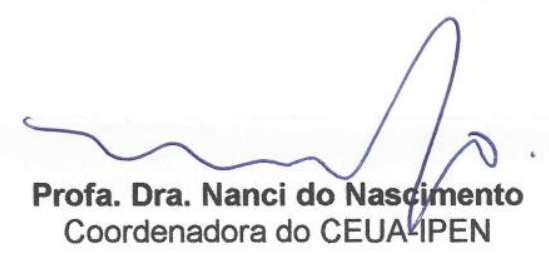

COMITÊ DE ÉTICA NO USO DE ANIMAIS

Av Prof Lineu Prestes, 2242 - Cidade Universitária - CEP 05508-000 - São Paulo - SP

Telefone: (011) 3133-9696 - Fax (011) 3133-9709

E-mail: nnascime@ipen.br 
ANEXO 2 


\section{ANEXO 1 - ARTIGO SUBMETIDO PARA PERIÓDICO INTERNACIONAL}

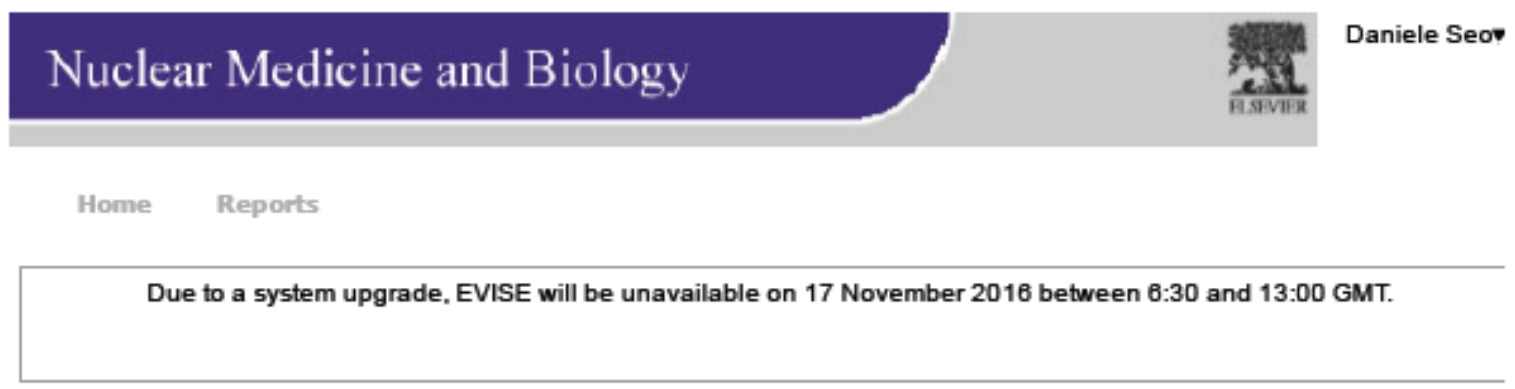

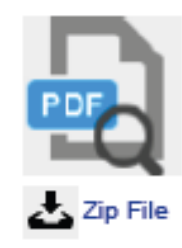

Overview

NUCMEDBIO_2016_301 | Research Paper

Pancreas and liver uptake of new radiolabeled incretins (GLP-1 and Exendin-4) in models of diet-induced and diet-restricted obesity

Daniele Seo I Institute of Energetic and Nuclear Research, Brazil.

Status: With Editor (0 days) | Submitted: 16/Nov/2016

Other Authors Show Details

Bluma Faintuch (Institute of Energy and Nuclear Research), Erica

Aparecida de Oliveira (Pharmaceutical Sciences School), Joel

Faintuch (Medical School) 